I N TERNATI O N A L

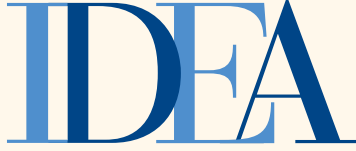

I N S T I T U TE FOR

DEMOCRACY AND

E L E C T O R A L

A S S I S T A N C E

\title{
INTERNATIONAL IDEA
}

Supporting democracy worldwide

\section{DEFENDING DEMOCRACY Annual Outcome Report 2020}

(1) 1995

LOOKED BRIGHT

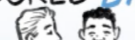

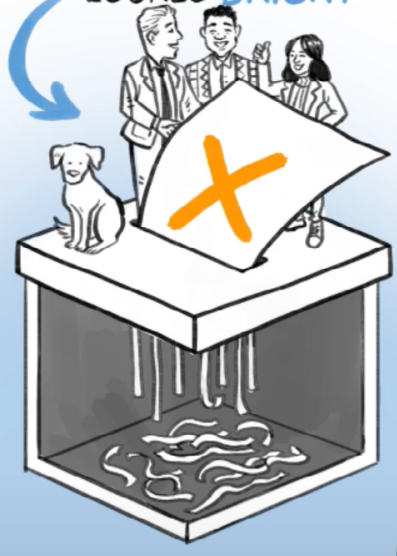

A GENERATION LATE DEMOCRACY FACESA SXISTENTIIAL THREAT

(1) 1010

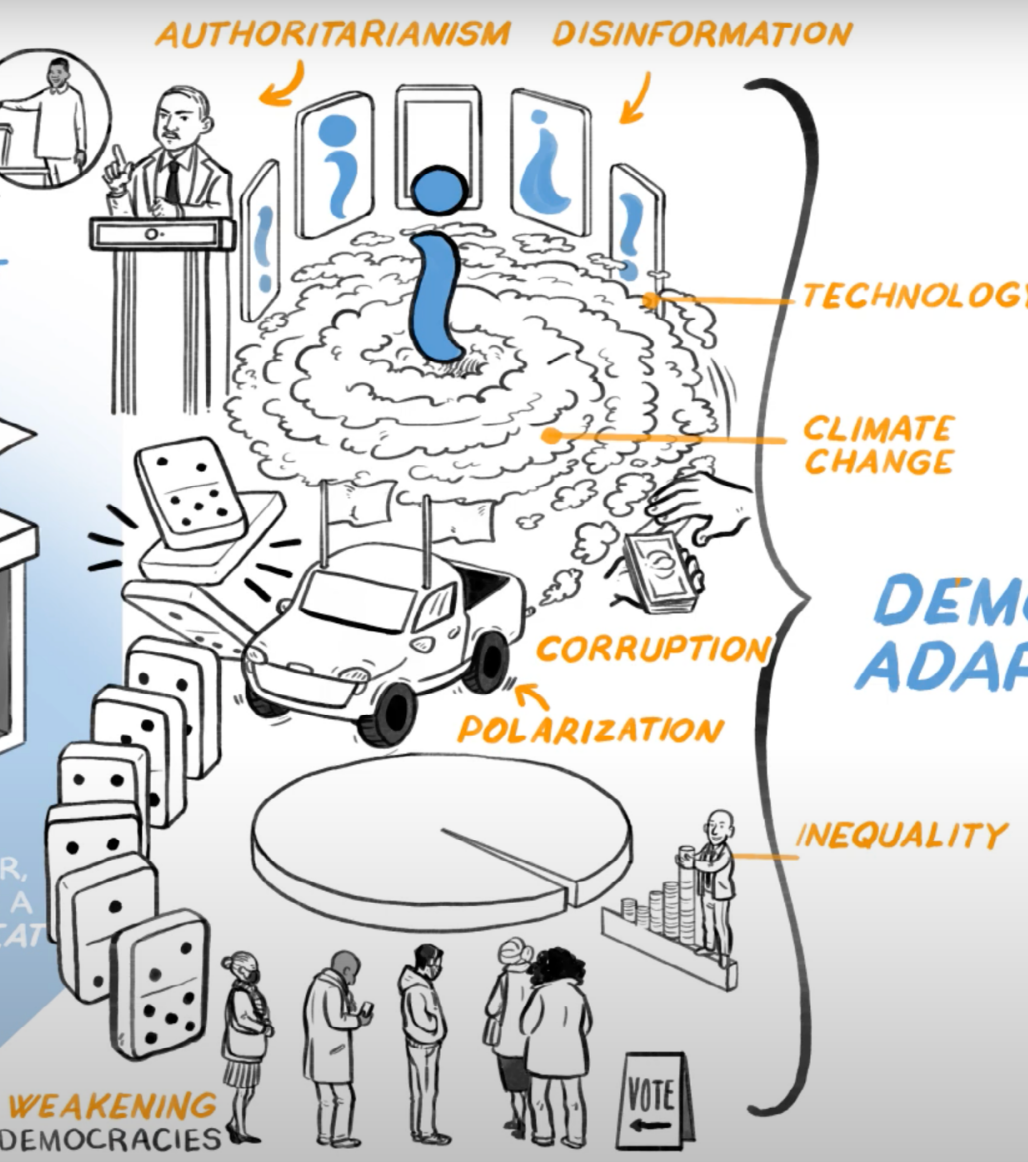


Graphic design template: Vision Communication ISBN: 978-91-7671-417-1

DOI: 〈https://doi.org/10.31752/idea.2021.44>

Disclaimer: Maps presented in this report do not imply on the part of the Institute any judgement on the legal status of any territory or the endorsement of such boundaries, nor does the placement or size of any country or territory reflect the political view of International IDEA. Maps are used in order to add visual clarity to data.

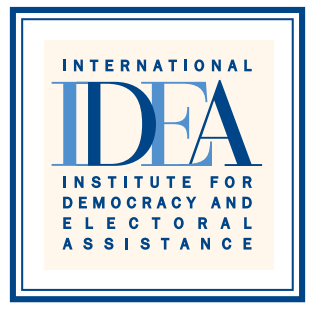

rnational IDEA

SE-103 34 Stockholm

SWEDEN

$+4686983700$

info@idea.int

(nwwidea int

www.idea.int

@Int_IDEA

f InternationalIDEA

(우) international_IDEA

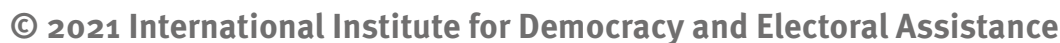

International IDEA publications are independent of specific national or political interests. Views expressed in this publication do not necessarily represent the views of International IDEA, its Board or its Council of Member States.

\section{DEFENDING DEMOCRACY}

\author{
Annual Outcome Report 2020
}


Annual Outcome Report 2020

\section{Contents}

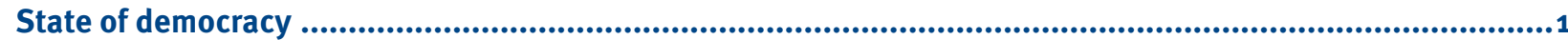
Letter from the Secretary-General...................................................................................................................1

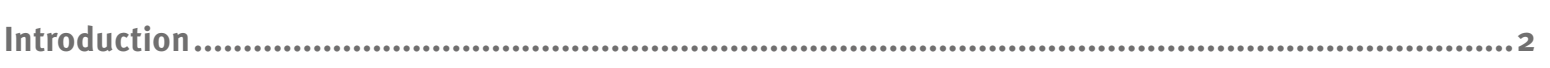

Project Overview

The Global State of Democracy ...............................................................................................................4

Global Monitor of Covid-19's Impact on Democracy and Human Rights ..................................................10

Highlights...................................................................................................................................................14

Call to Defend Democracy Attracts Worldwide Media Attention ................................................................16

Joining efforts to protect democracy in Latin America .............................................................................17

Elections and Covid-19-Helping authorities make informed decisions ................................................18

25th Anniversary ..........................................................................................................................20

Deepening our collaboration with the host country and 2020 Council of Member States chair .............22

Outcome stories.

International IDEA supports understanding and analysis of the relationship between constitutions and emergency responses to Covid-19 ............................................................................................26

International IDEA supports South Sudan's transition to a peaceful democratic federation....................28

The Melbourne Forum: regional community of experts consolidated and regional experience on constitution-building elevated ................................................................................................................30

MyConstitution enables ethnic armed organizations to advocate positions on federalism .................... 32 International IDEA's constitution-building expertise supports Armenia's State Constitutional Reform Commission ........................................................................................................................34

Implementing a framework for developing internal gender policies for electoral

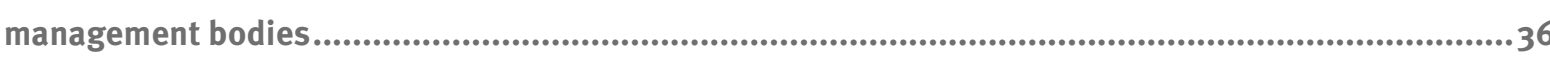

Assisting European electoral commissions handle Covid-19 through special voting arrangements.......38

Enhancing the independence of electoral management bodies in the Arab region 2

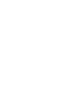
10

16

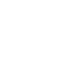

\section{4} 30 32 34
Conducting safe democratic elections during the Covid-19 pandemic in Africa .......................................42 Promoting best practices among electoral management bodies in Southern Africa ...............................44 Guiding Indonesian stakeholders to navigate the impact of Covid-19 on elections................................46 Promoting pioneer management of Covid-19 era elections by the Republic of Korea .............................48 Myanmar 2020 elections: helping a democratic transition ..................................................................50 Empowered CSOs contribute to electoral risk management.................................................................52 Strengthening electoral cooperation in Latin America ...............................................................................55 Institutionalizing election observation within the Melanesian Spearhead Group ..................................56 Helping trans people vote in Peru .....................................................................................58 Electoral authorities to advance on key policy decisions that address electoral challenges during Argentina's pandemic ......................................................................................................................60 From the sidelines to centre stage: Bangsamoro young people ready for their future...........................62 Partnering for online political advertising and microtargeting reforms in Europe.................................64 Bringing gender violence against women in politics into focus in Paraguay .........................................66 Supporting political finance reforms in Commonwealth countries ........................................................68 Making a virtue of virtuality: legislative drafting knowledge exchange with the Parliament of Bhutan Renewing the AGORA Parliamentary Development Web Portal..........................................................72 Supporting Nepal's locally elected representatives in understanding deliberative decision-making .......................................................................................................................74 Guiding the EU towards a stronger EU Action Plan on Human Rights and Democracy ............................76 International IDEA helps EU's pandemic response focus on democracy ..............................................78

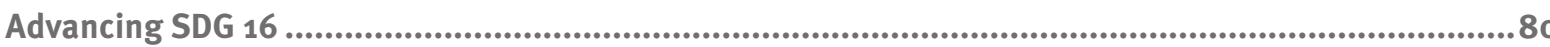

2020 Review in numbers ........................................................................................................................................82

Results Framework 


\section{Letter from the Secretary-General}

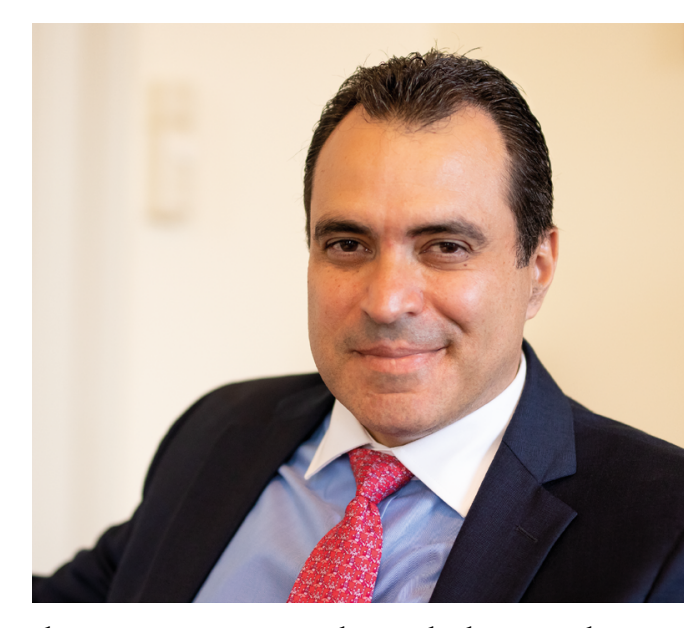

At the beginning of 2020, few people could have accurately predicted the level of change and disruption that the year would bring us. The spread of the Covid-19 pandemic has taken an abysmal toll on people across the globe, generating a global health, economic and political crisis, with repercussion that will be felt long after the pandemic is over.

In response to the Covid-19 pandemic, International IDEA rapidly shifted its priorities and working practices. The outcome stories in this report give an account of how the organization successfully inspired and supported democratic actors throughout these challenging times by developing and disseminating new knowledge, analysis and tools which our partners have utilized to adapt their practices, but also by creating a global coalition to defend democracy worldwide.

International IDEA was quick to recognize that the pandemic would have a serious impact on electoral processes. As questions arose about whether or not to hold elections and how to use special voting arrangements, our talented staff swiftly produced knowledge products and tools to support election administrators around the world to adapt their practices. Another serious concern was how governmen emergency responses to the pandemic would affect democracy and human rights, and how authoritarian regimes would use the pandemic as a pretext to further enhance their power. To enable democratic actors to hold policymakers to account, International IDEA developed a Global Monitor that continuously tracks the impact of Covid-19 measures on various aspects of democracy and human rights in 162 countries.

The year 2020 has not only changed what we worked on; it also affected how we work. The shift to digital meetings and knowledge resources was accelerated and helped to enhance the visibility and outreach of International IDEA's work. The new challenges and threats to democracy, spurred by the Covid-19 pandemic, also inspired us to create new alliances and partnerships in defence of democracy. Together with our partner organizations, International IDEA initiated a global advocacy campaign, the Call to Defend Democracy, which gathered a remarkable coalition of more than 70 democracy organizations. The campaign was endorsed by 500 signatories, including former heads of state, Nobel prize laureates, thought leaders, academics, journalists and activists. International IDEA's 25th anniversary, organized together with Sweden as the 2020 Council Chair, strengthened and developed these partnerships with our Member States, democracy experts, global policymakers, and representatives from civil society and youth in a series of 12 webinars.

Our transformative work in strengthening democracy will intensify in 2021. We will continue to develop our global partnerships and collaboration with Member States to defend, inspire and support democratic institutions worldwide. To help our partners develop their democratic practices, we will continue to produce cutting-edge, policy-friendly knowledge in our areas of expertise, but also develop new workstreams linked to issues such as disinformation and climate change. To be able to inspire more democratic organizations and actors worldwide, we will continue to increase our online activity by actively engaging in digital campaigns, webinars and online events. The launch of the third iteration of the Globa State of Democracy report towards the end of 2021 will be one of the highlights of this year. We hope you will join us on this journey.

\section{Dr Kevin Casas-Zamora}

Secretary-General
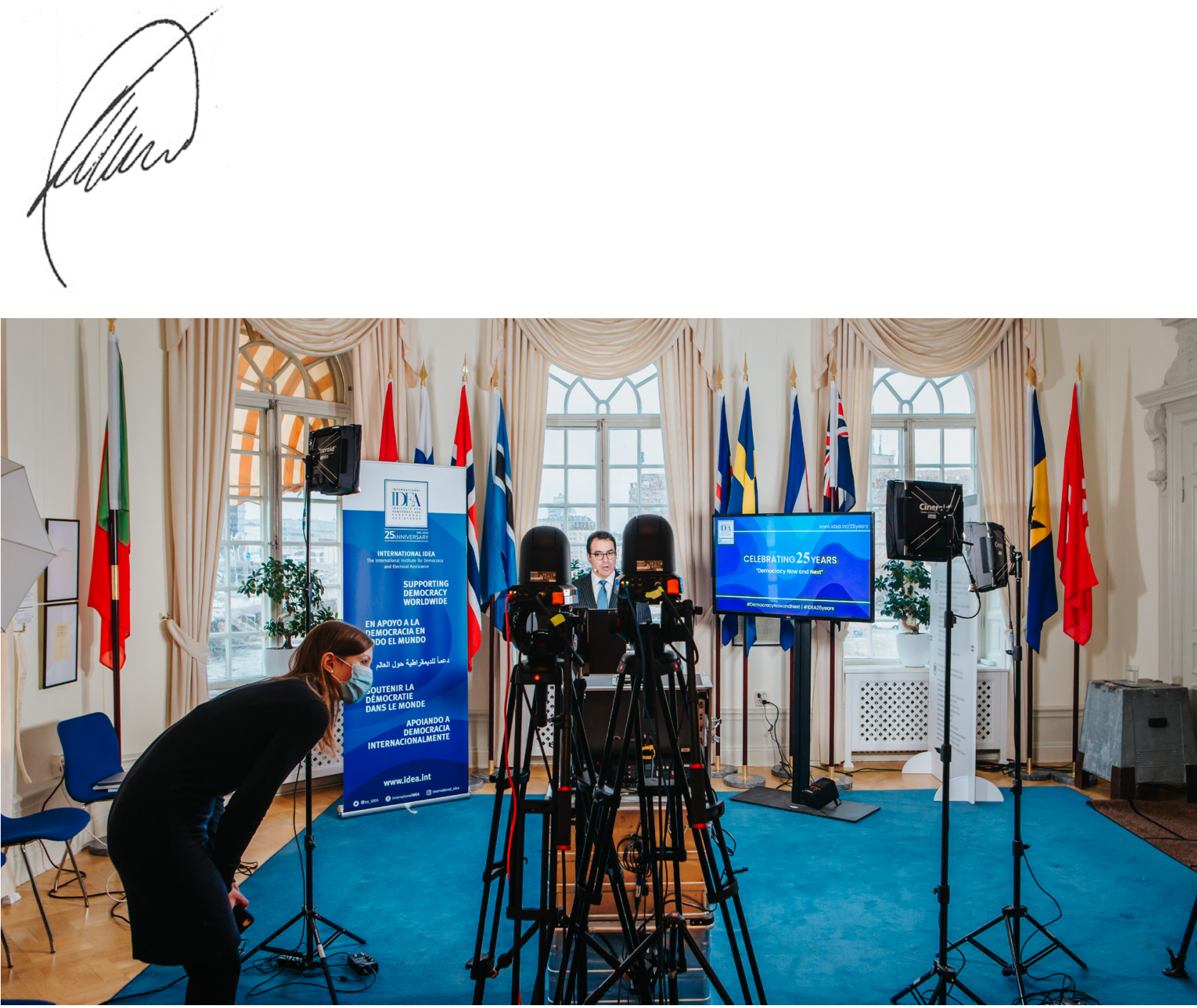

Celebrating 25 years at International IDEA headquarters on Strömsborg in Stockholm, Sweden. 


\section{Our mission}

At International IDEA, we advance democracy worldwide, as a universal human aspiration and an enabler of sustainable development, through support to the building, strengthening, and safeguarding of democratic political institutions and processes at all levels.

\section{Our approach}

We believe democracy is a universal human aspiration and an experience that is pursued and lived in different ways around the world. It comes in multiple forms, which are in constant evolution. There is no single and universally applicable model of democracy, just as there is no end point in improving democracy. Fundamentally, democracy is a system in which the people control the government and citizens are considered equals in the exercise of that control. Beyond the basic tenets of citizens' choice and political equality, the critical choices are best made (and the quality of democracy is best gauged) by those directly concerned-the citizens themselves. We systematically nurture an open and pluralistic understanding of democracy. This understanding is respectful of the national context, and in line with our non-prescriptive and non-intrusive approach, and with the priorities set by national actors.

Learn the latest information about our activities, our Member States, Board of Advisers and Secretariat, as well as how you can get involved in supporting democracy worldwide.

Our global reputation for knowledge and expertise

In 2020, International IDEA enjoyed one of its most visible and impactful years with its swift and comprehensive reaction to the Covid-19 pandemic, especially highlighting the impact on elections and leading the Call to Defend Democracy campaign. It helped set the agenda with policymakers and the media for a host of issues ranging from the US presidential election to Chile's constitutional reform, special voting arrangements and gender quotas in Japan. International IDEA has appeared in some of the world's leading media outlets with citations from our work, expert commentary and opinion pieces.

It featured in over 400 global media outlets in 2020, including many of the world's top media names: The New York Times, Washington Post, BBC, CNN, Al Jazeera, Reuters, Bloomberg, AP, AFP, EFE, Deutsche Welle, Le Monde, El Pais, Times of India, Globo TV, Television Española, Swedish Radio, Le Figaro, La Repubblica, Norwegian Public Radio, Politico, Voice of America, NBC, Newsweek, Jakarta Post, etc.

International IDEA Secretary-General Kevin Casas-Zamora had 778 mentions as a spokesperson in articles in 2020.

Increased media impact and outreach efforts are vital to sustaining International IDEA's ability to contribute to tangible outcomes in our areas of expertise.

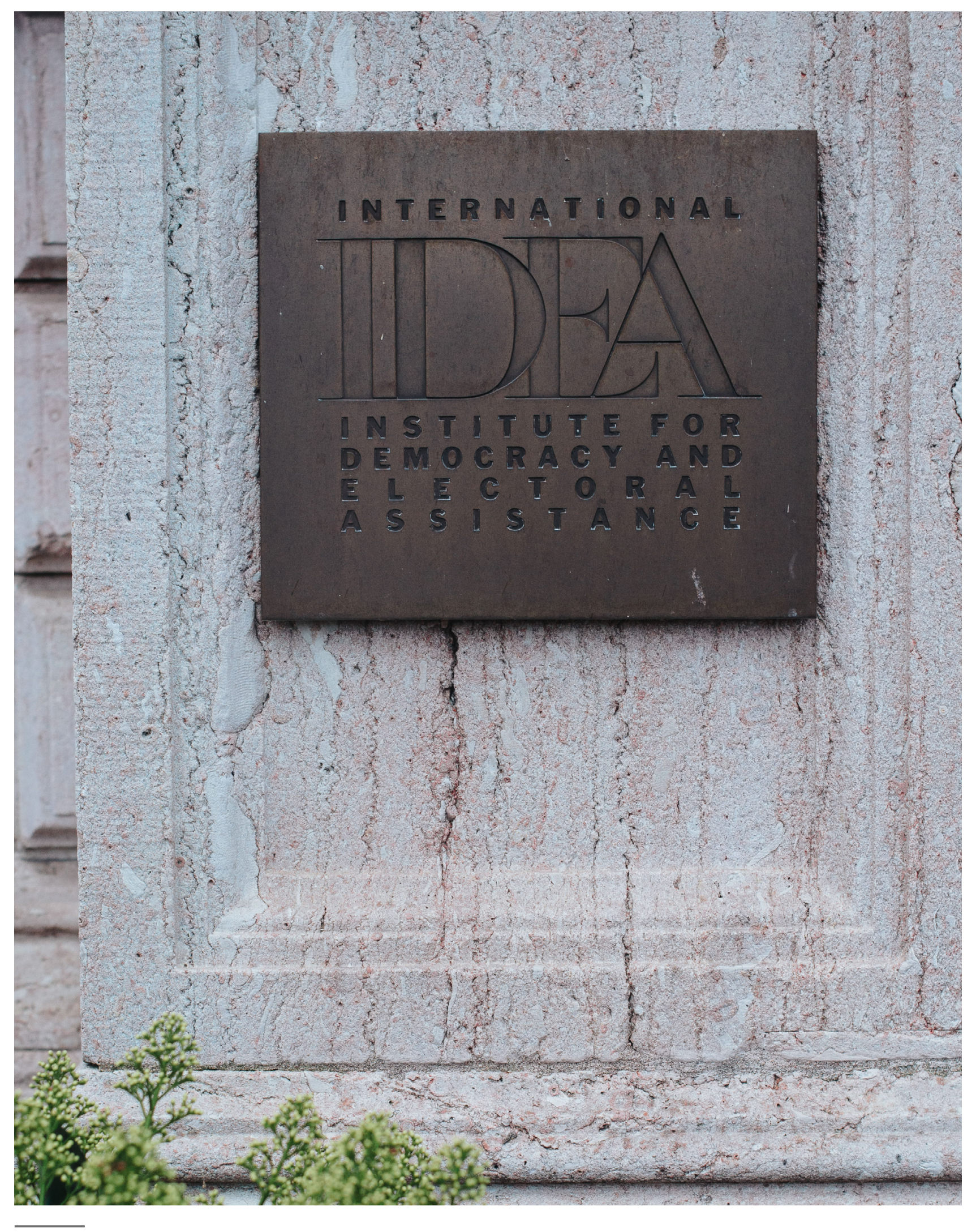

Photo credit: Malin Huusmann 


\section{The Global State of Democracy}

Since its launch in 2017, the Global State of Democracy (GSoD) report has prompted great interest from international media and policymakers around the world, cementing its reputation as an authoritative source on democracy worldwide. The report has generated more downloads than any other publication in International IDEA's history.

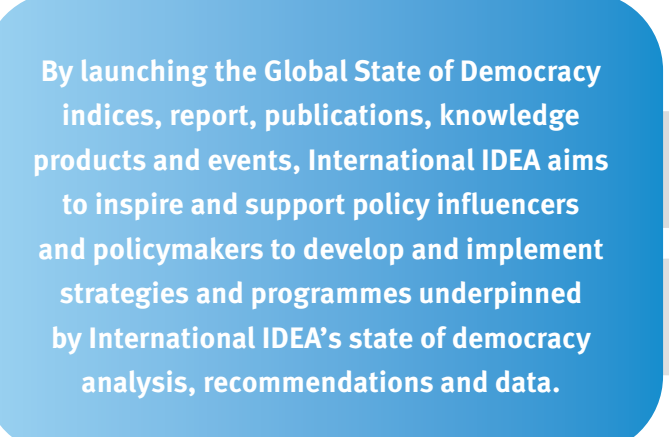
Boundary partners: International, regional and national

Funding: Core
The Swedish international development cooperation agency, Sida, has used the GSoD data and analysis as a reference in its democracy analysis and democracy support programmes. For example, Sida’s 2020 Strategic Report in support of political party organizations referenced GSoD data. The Swedish Ministry of Culture also made use of the GSoD report in their Democracy Strategy for 2018-2022. In addition, International IDEA has provided various training sessions on the GSoD Indices to Swedish Ministry for Foreign Affairs and Sida staff.

Hans, Ola and Anna Rosling's public education foundation Gapminder have used the GSoD Indices as part of their publication education visualizations on sustainable development; they expanded their field into the democracy arena in 2018. Gapminder now features the GSoD Indices on the data section of their website, so readers can use International IDEA's data to generate Gapminder's famous 'bubble' presentations.

Ola Rosling, Gapminder's founder and director, participated in and delivered a speech at the 2019 GSoD launch in Stockholm, where he stated his great appreciation for the GSoD Indices' enriching contribution to the global democracy field.

"This dataset (GSoD Indices) is richer than any other I have ever seen."

- Ola Rosling, Founder of Gapminder / December 2019

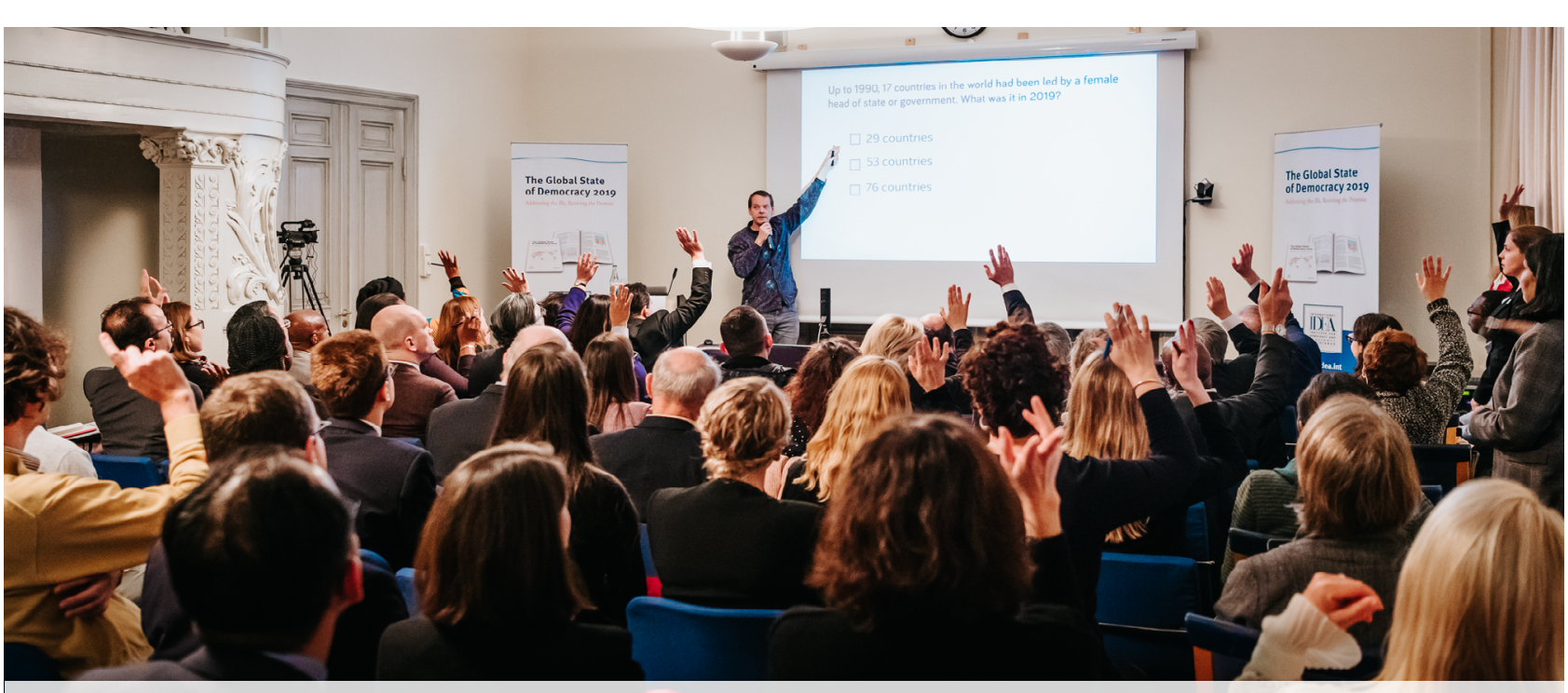

The founder of Gapminder, Ola Rosling, conducts an interactive survey during the Stockholm launch of the GSoD 2019 Report. Photo credit: Malin Huusmann from 304 outlets in 61 countries since November 2017; the 2019 report generated more than half of those visible in 2020: visits to the site quadrupled in 2020 compared to 2019.

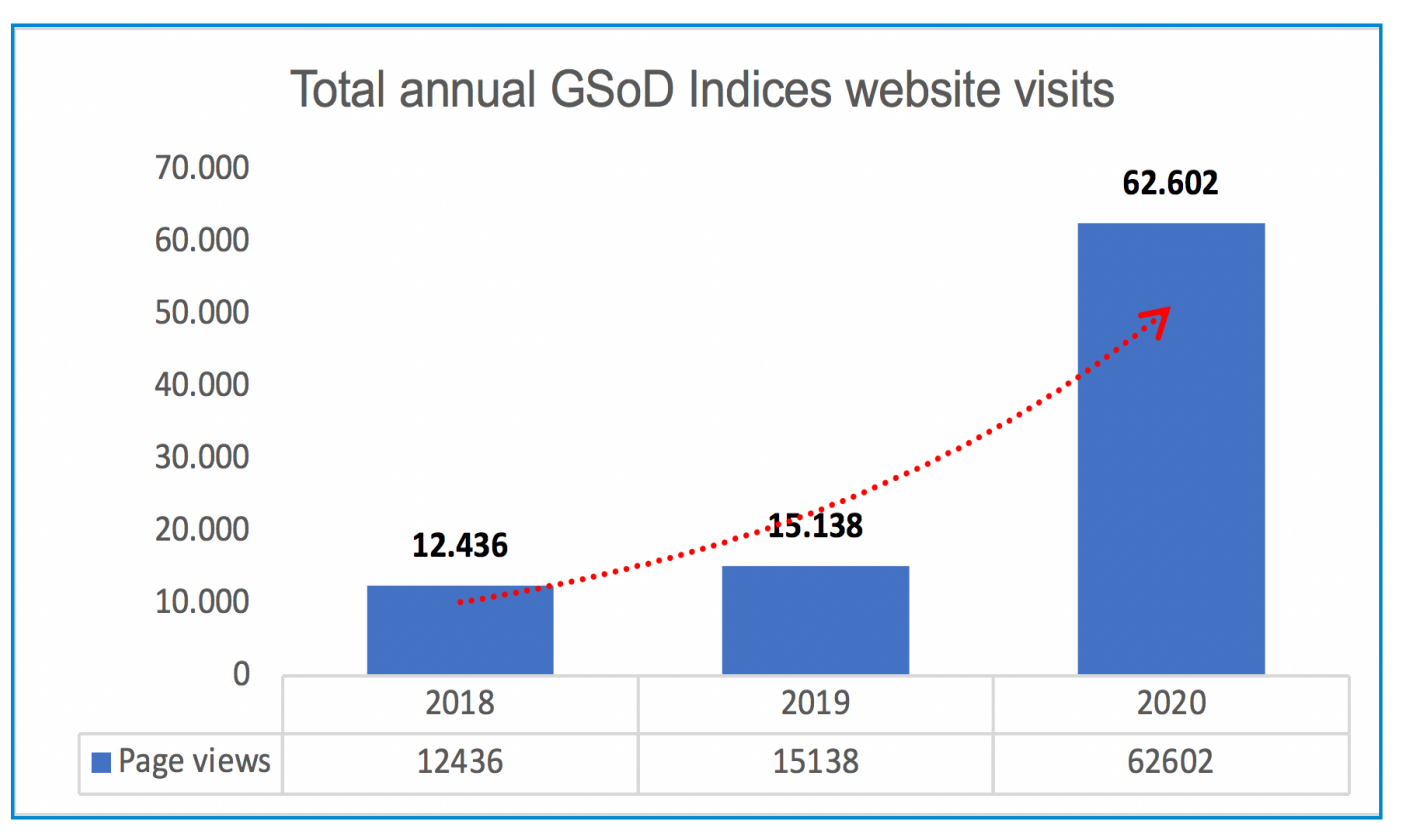




\section{The Global State of Democracy}

The report has also received interest from the World Bank, where the Governance Global Practice organized an interactive session to present the key findings of the GSoD 2019 report. Moreover, GSoD Indices data is featured in the World Bank's GovData360 portal, which compiles key governance indicators for all countries in the world.

The GSoD Indices have also generated interest from the United Nations Development Programme (UNDP): Deputy Assistant Administrator and Deputy Director of the UNDP's Bureau for External Relations and Advocacy, Gulden Turkoz-Cosslett, participated in the panel launch of the GSoD 2019 report at the United Nations in New York in December 2019

"The report provides important points for organizations like the UN to pick up on, and it is important to understand the role that democracy has on sustainable development. The data collected by this report and provided are of immense importance."

- Gulden Turkoz-Cosslett, Deputy Assistant Administrator and Deputy Director of the Bureau for External Relations and Advocacy, UNDP / December 2019

On Anticorruption Day in December 2019, the UNDP tweeted a statement, referencing data from the GSoD Indices:

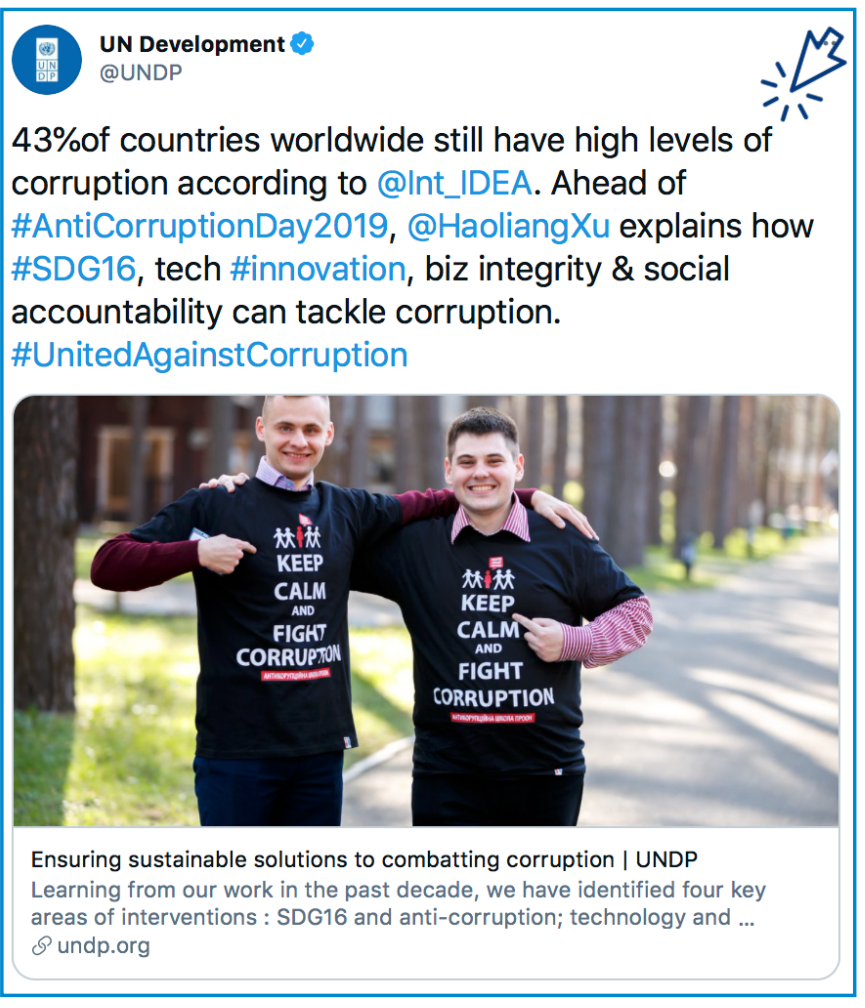

Kevin Casas findings from @Int_IDEA's \#GlobalStateofDemocracy report with our friends in \#Mongolia, one of our Member States and a very successful \#Democracy. Honored to share the floor with H.E. N. Ankhbayar, State Secretary of Foreign Affairs of Mongolia.

International IDEA @Int_IDEA What are the key findings from @Int_IDEA's \#GlobalStateofDemocracy report concerning the state of democracy in \#Asia \& \#thePacific? What are the challenges and lessons from organizing \#elections in \#Mongolia during the \#pandemic? TOMORROW $\odot 9: 00$ am CET bit.ly/37UL5jJ
I'm very pleased to discuss the
The GSoD Programme provides stakeholders, including policymakers and civil society representatives, an in-depth assessment of the global democracy landscape with the aim of influencing and informing policy interventions. A success in this regard has been the continuous usage of GSoD data and analysis by the Swedish Ministry for Foreign Affairs and Sweden's missions abroad, widely applied throughout the department as well as at the regional level.

"The GSoD database and indices has been extensively used by the Swedish Ministry for Foreign Affairs in various ambassador and department meetings. We have created a number of diagrams based on the GSoD data that have been very useful in presentations to our colleagues in the MFA as well as its political leadership."

- Anna Jakenberg Brinck, Deputy Director and Head of Democracy and Development Unit, Sweden's Ministry for Foreign Affairs / November 2020

The programme also aspires to spread its knowledge beyond the policymaking community. Outreach to an international audience of students and opinion makers within academia and research institutions has increased the usage of GSoD data and knowledge products for both academic courses and research. At least 36 universities around the world have used GSoD knowledge products and data for their courses or research. A few examples include:

- Fordham University, New York, USA. A professor at the Department of Political Science requested numerous printed copies of the GSoD 2019 report for his students to use as a reference during his seminar 'The World of Democracy'.

- University of Southern California, USA. Two courses assigned the GSoD 2019 report as required reading in Spring 2020—-the undergraduate-level 'Global Democratization' and the graduate-level 'Democracy and Democratization'

- Stockholm University, Sweden. The core undergraduate and postgraduate programmes of multiple courses in the Political Science Department have used GSoD analyses and products. The Director of Studies for the Department of Asian, Middle Eastern and Turkish Studies, Martin Säfström, has also incorporated the GSoD into the curriculum of several Middle East/North African politics and development courses.

- Södertörn University, Sweden. The course 'Comparative Governance' references GSoD data and analysis in the study of political regimes and development of democracies over the last 50 years.

"The GSoD report measures the main components of democracy, looks into the future and studies potential problems. The report is useful for both scholars and practitioners because of the significan statistical data it offers."

- Abraham Lowenthal, Professor Emeritus of International Relations, University of Southern California I December 2019 


\section{The Global State of Democracy}

The Swedish Minister for Foreign Affairs, Ann Linde, praised the invaluable evidence provided by the GSoD report and the Covid-19 Global Monitor in her speech at International IDEA's 25th anniversary global conference. She recognized the initiative as a crucial reference point for monitoring challenges to human rights and the development of democracy around the world'.

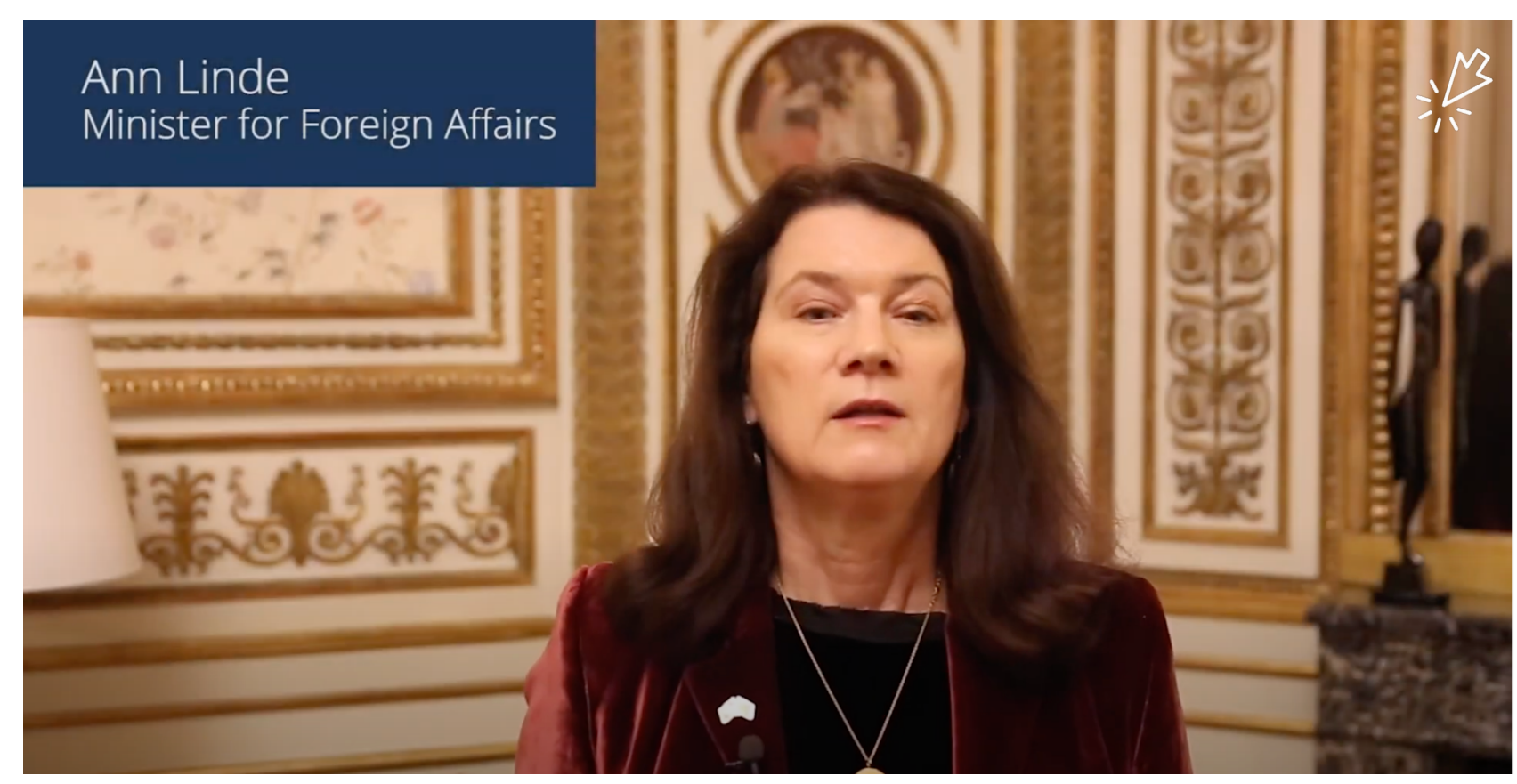

The GSoD in Focus was quoted in several international and national newspapers, including Dagens Nyheter, BBC and El Pais, and was discussed on TV4 in Sweden's 'Nyhetsmorgon' and will be featured on 'Vetenskapen Värld', a scientific programme on Swedish television. The European Centre for Disease Prevention and Control has also contacted International IDEA to conduct a seminar for its staff on the findings of the GSoD in Focus.

The Swedish Minister for International Development Cooperation, Peter Eriksson, publicly celebrated the GSoD initiative by praising its quality in social media, highlighting the importance of International IDEA's work during our 25th anniversary.

\section{Peter Eriksson \\ @MPPeterE}

Pleased to join the 25th anniversary celebrations of @int_IDEA today - an important partner for 1 in efforts to promote and defend democracy worldwide. IDEA's top-flight work to monitor the global state of democracy is key in times of democratic backsliding \#drivefordemocracy

$\cdots$

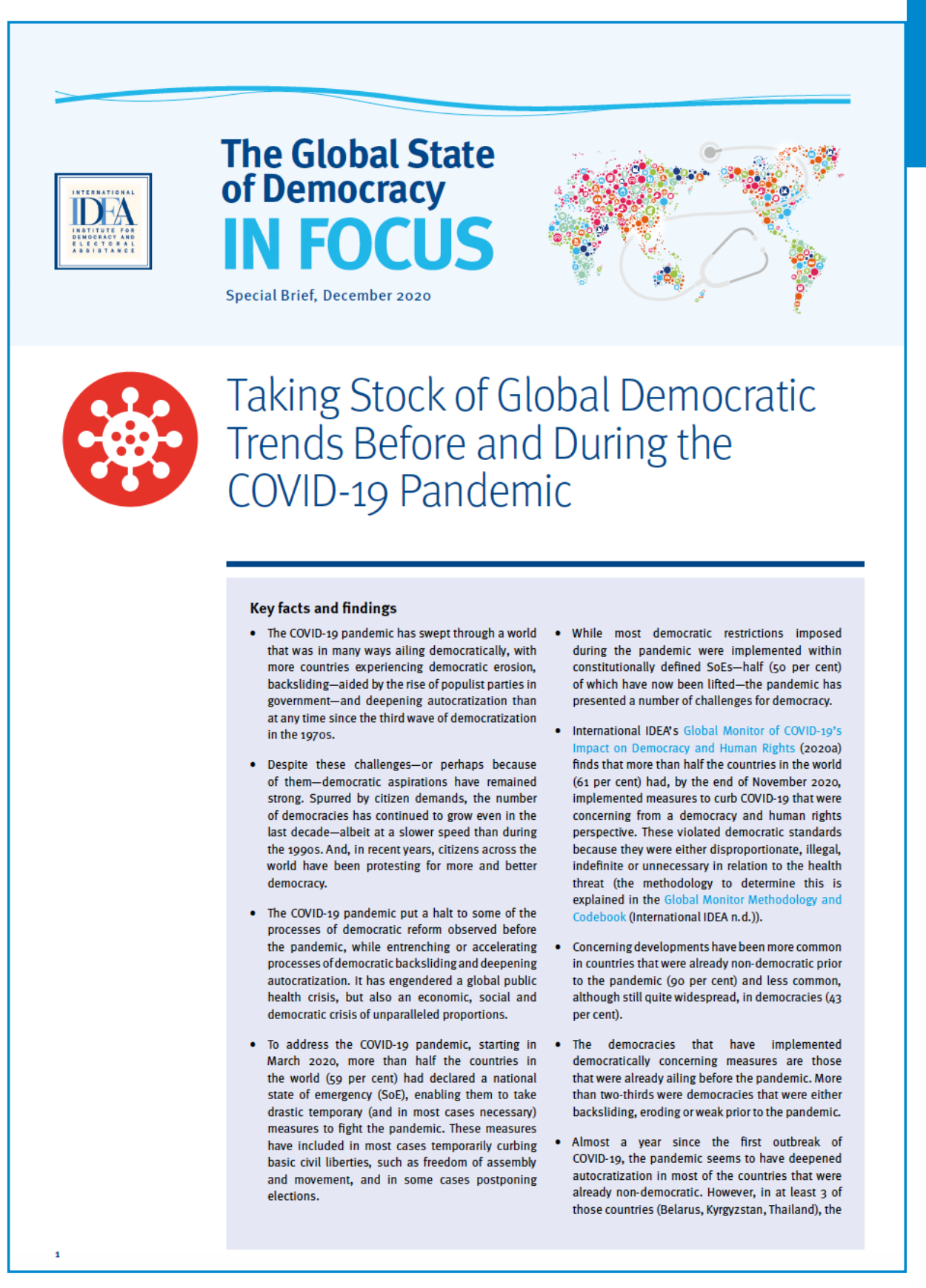

Number of downloads of GSoD In Focus published in 2020: total 4,277 (as of end of January 2021) 


\section{Project Overview}

\section{Global Monitor of Covid-19's Impact on Democracy and Human Rights}

International IDEA's Global Monitor of Covid-19's Impact on Democracy and Human Rights project was launched in July 2020 with support from the European Union and the European Parliament.

By launching a Global Monitor on Covid-19's Impact on Democracy and Human Rights, Iitternational IDEA helps policymakers consider risks and inspirss policy infiuencers to place threats to democracy on the public agenda and to hold policymakers accountable.

Boundary partners: Policy influencers and policymakers

Funding: European Union

\section{A 'one-stop-shop' tool}

The online Monitor is a 'one-stop-shop' tool for assessing the democracy and human rights implication of measures adopted by governments to curb the Covid-19 pandemic. This digital platform is updated every two weeks and includes the 162 countries covered by the GSoD Indices, aggregating up-to-date information to offer individual country profiles, with links and data on events and trends across regions. The Global Monitor contributes to the debate on the pandemic's impact on democracy globally and makes it possible to hold policymakers accountable.

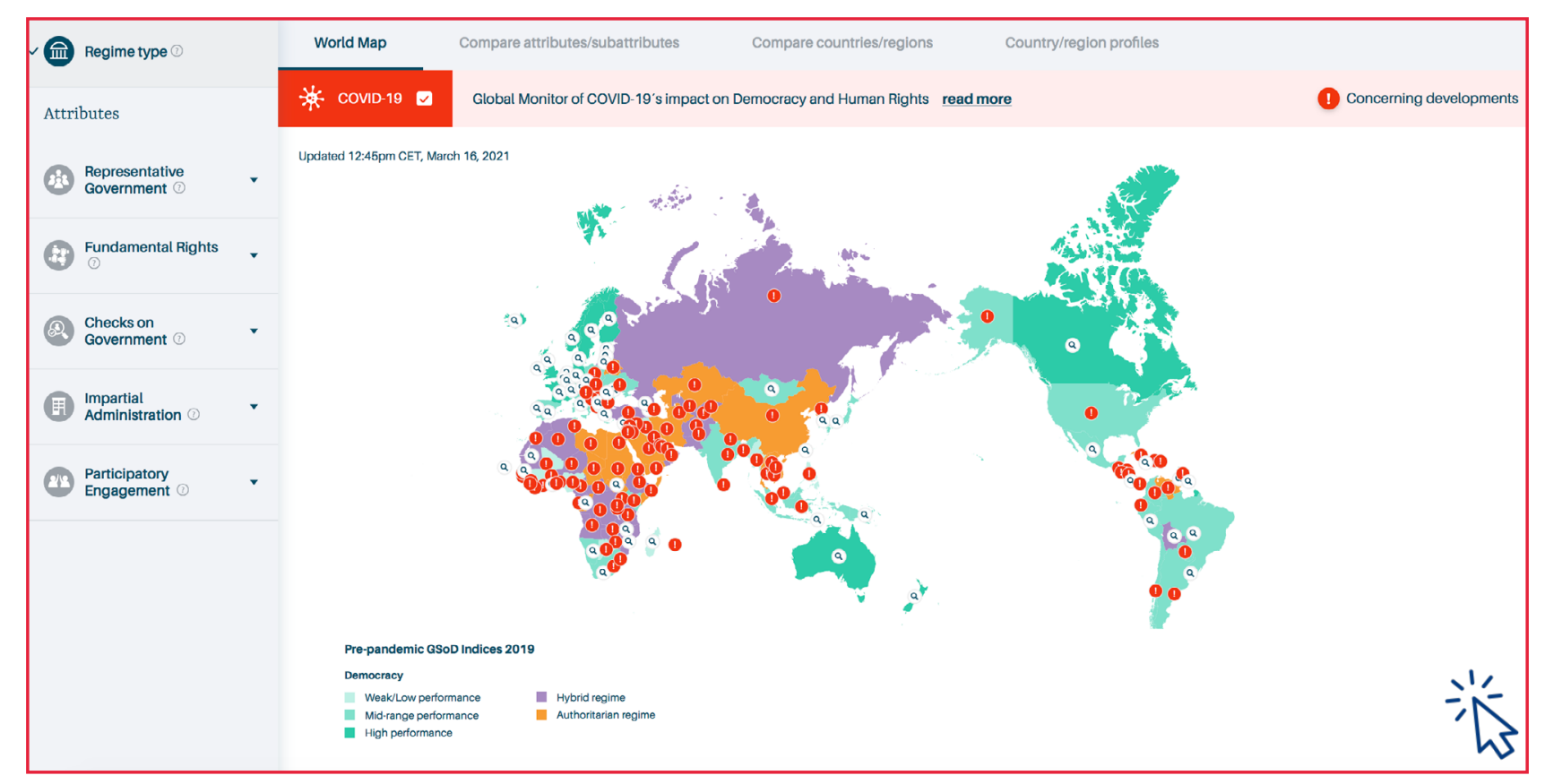

\section{* COVID-19 \\ Global Monitor of COVID-19's impact on Democracy and Human Rights read more}

Updated 01:36pm GMT, March 03, 2021

World ${ }_{\text {(covio-19) }}$
0.00-0.399 Low performance $\quad 0.40-0.70$ Mid-range performance $\quad 0.701-1.00$ High performance

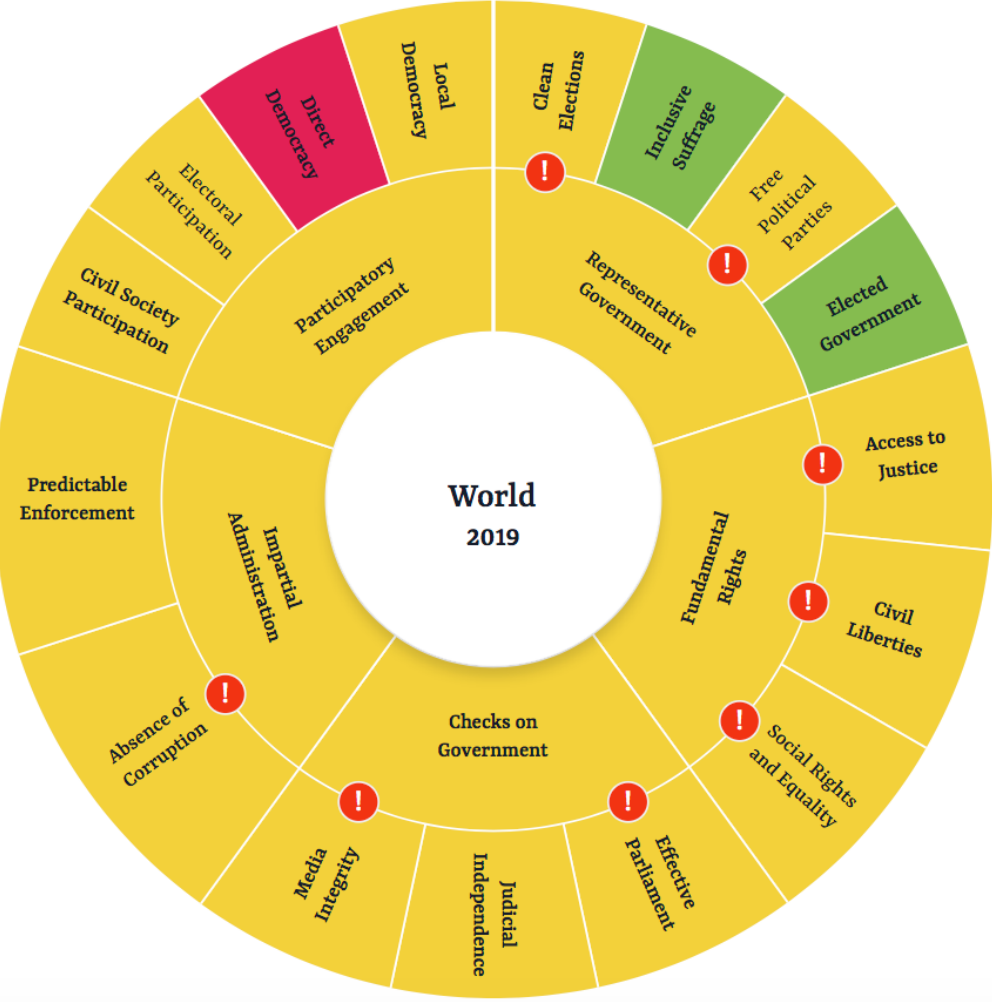

"I am delighted that the EU has partnered with International IDEA to develop the monitoring tool going live today. This tool provides reliable data and analysis on developments in 162 countries in the world. The Global Monitor strongly reflects across-the-board cooperation. Its data will be in use by both the Commission and European Parliament."

- Jutta Urpilainen, EU Commissioner for International Partnerships / July 2020

The data collated on the Global Monitor illustrate numerous cases of democratic violations justified as necessary to curb the pandemic. The most worrisome violations are restrictions on the freedom of expression and media integrity. 


\section{Global Monitor of Covid-19's Impact on Democracy and Human Rights}

The Covid-19 Global Monitor has generated huge interest among policymakers, and its preliminary findings have been presented in various (virtual) fora around the world.

In September 2020, Therese Pearce Laanela, International IDEA's Head of Electoral Processes, participated in a hearing held by the US House Foreign Affairs Subcommittee on Europe, Eurasia, Energy and the Environment on how to protect democracy in Europe and Eurasia. Her testimony illustrated how Covid-19 has challenged democracy, and particularly elections, and cited data and examples from the Global Monitor and the GSoD Indices.

The European Parliament Subcommittee on Human Rights invited International IDEA to provide testimony at its virtual hearing on human rights during the Covid-19 pandemic. Annika Silva-Leander and Elisenda Ballesté-Buxo presented some key findings from the Global Monitor at the hearing, which raised great interest among the parliamentarians.

The Global Monitor has generated considerable interest within the international community. International IDEA has been invited to numerous panel discussions and webinars to present its findings, including by the European Union, Deutsche Gesellschaft für Internationale Zusammenarbeit (GIZ), the Organization for Security and Co-operation in Europe, the Organisation for Economic Co-operation and Development, and the US Agency for International Development.

The United Nations Entity for Gender Equality and the Empowerment of Women (UN Women) requested Global Monitor data on developments and violations of the Freedom of Association and Assembly, Freedom of Movement and Media Integrity. This information will be featured in an upcoming UN Women report. Similarly, the World Health Organization used the Monitor's world map in its annual report, Global Preparedness Monitoring Board: A World in Disorder.

The Praia Group on Governance Statistics mentioned the Global Monitor in its latest report, Governance Statistics in the Covid-19 Era: A Praia City Group Guidance Note.

A December 2020 Politico article reviewing the best and worst moments of 2020 for various EU commissioners named Commissioner for International Partnerships Jutta Urpilainen's best moment as the launch of the Global Monitor:

In July, Urpilainen launched the "Global Monitor of Covid-19's impact on Democracy and Human Rights," an interactive online tool that shows how governments worldwide are dealing with citizens' rights during the pandemic-naming and shaming countries using the virus to clamp down on democracy. Urpilainen received applause for not only looking beyond the EU's border, but also including the EU's own countries in the analysis.
In November 2020, International IDEA's Regional Director for Asia and the Pacific, Leena Rikkilä Tamang, participated in the Australia Senate Committee on Legal and Constitutional Affairs inquiry on the implications of Covid-19 for nationhood, national identity and democracy. She referenced the GSoD Indices and Global Monitor in her contribution. The Report by the Committee included a number of references to International IDEA submissions and to the witness.

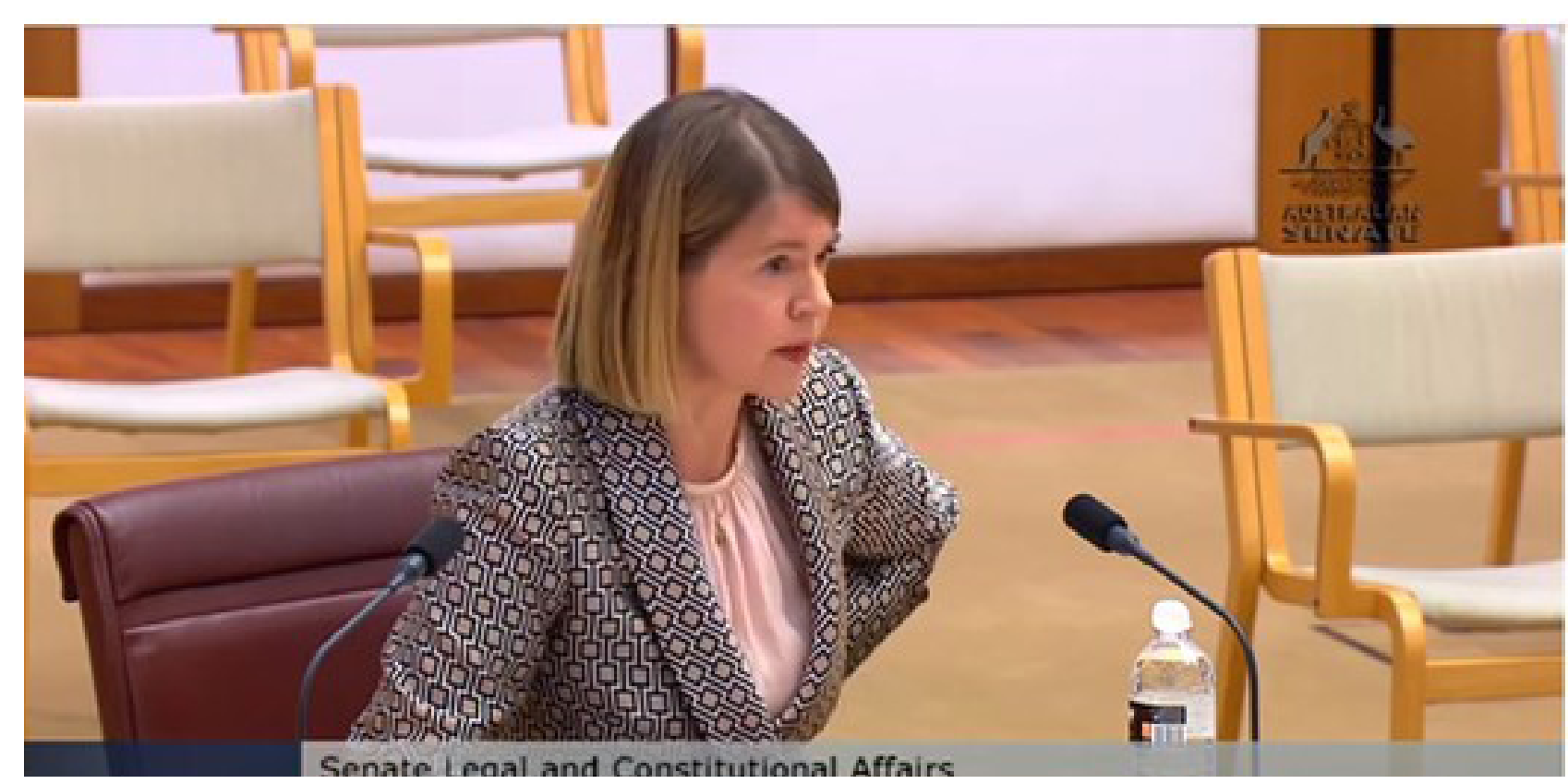

International IDEA's Regional Director for Asia and the Pacific, Leena Rikkilä Tamang, delivering her submission in the Australian Senate.

The number of visits to the GSoD Indices website increased tenfold from June to July 2020 after the Monitor's launch, compared to a doubling of visits during the same period in 2019.

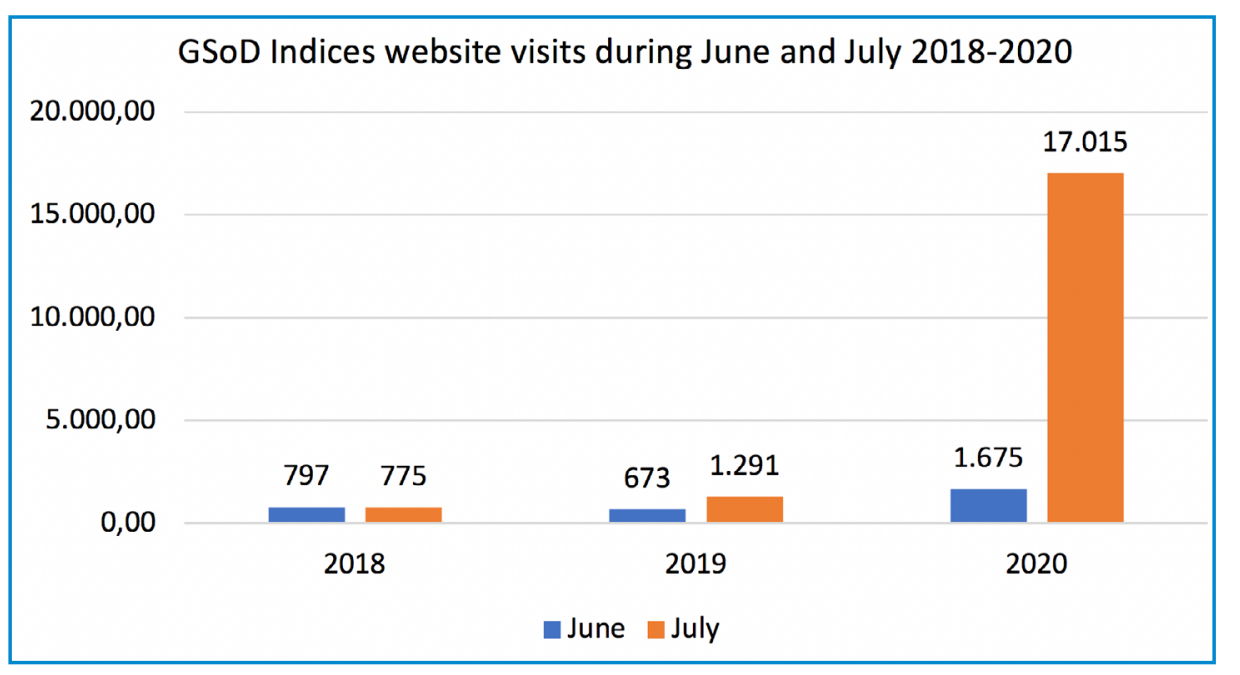


Highlights 


\section{Call to Defend Democracy Attracts Worldwide Media Attention}

In June 2020, International IDEA made headlines around the world when it launched 'A Call to Defend Democracy', a global advocacy campaign in support of democracy following the detrimental consequences posed by the Covid-19 pandemic.

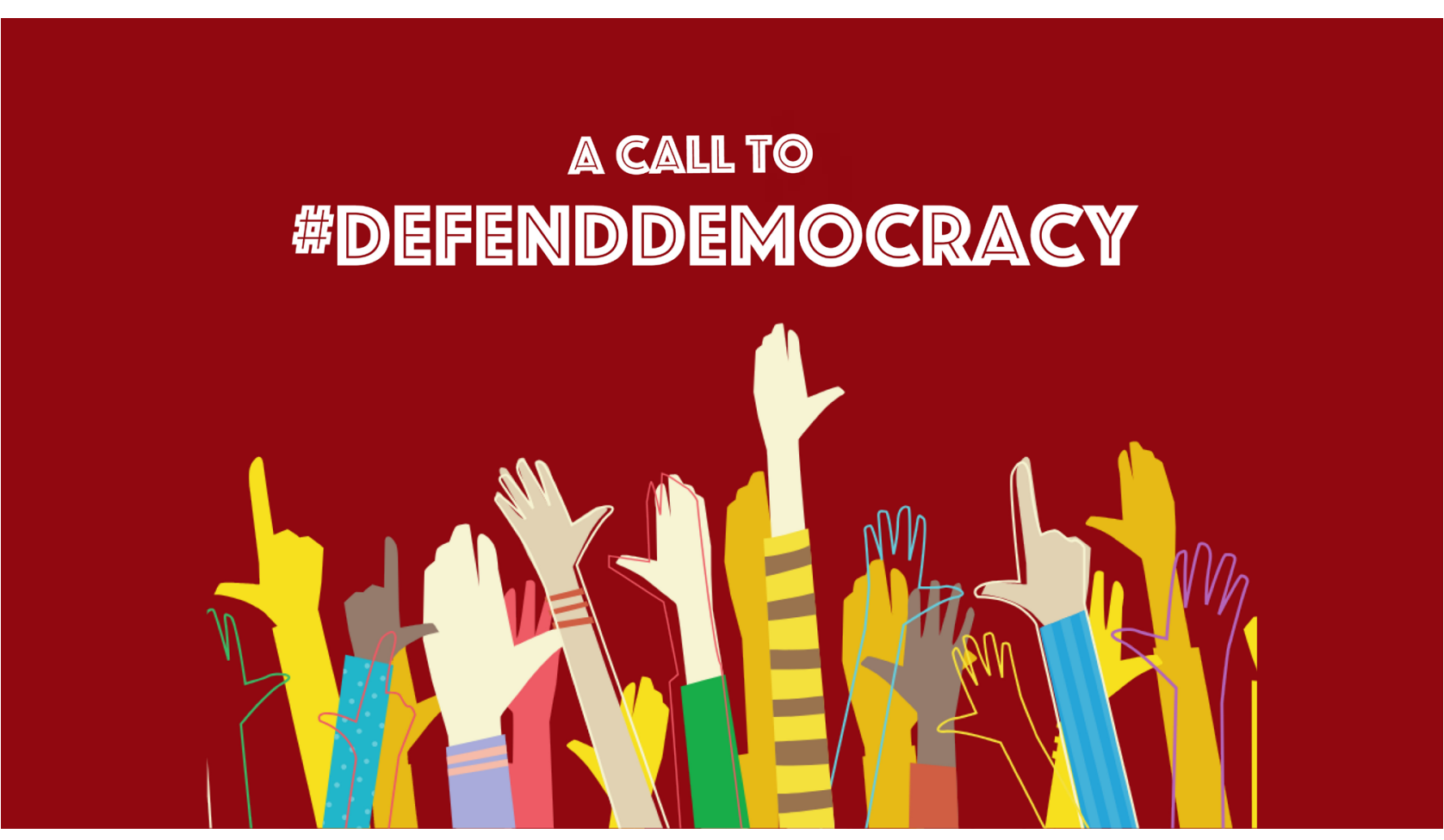

International IDEA initiated the open letter and coordinated the campaign together with a coalition of democracy organizations from around the world. The letter was endorsed by more than 70 organizations and nearly 500 prominent personalities from 119 countries, including 62 former heads of state and government, 13 Nobel laureates, distinguished scholars, journalists and activists, creating an impressive global coalition of democracy supporters.

The campaign attracted media attention around the world and was covered in all major global outlets, including The New York Times, Reuters, AFP, Le Monde, The Times of India and Al Jazeera. Incoming US President Joe Biden also referenced the campaign to millions of his followers on social media. As a result, the Call to Defend Democracy raised International IDEA's profile and visibility, and strengthened the Institute's collaboration and networks with key democracy-building organizations and think tanks.

As a follow-up to the open letter, the European Endowment for Democracy and International IDEA developed a policy paper called Global Democracy and Covid-19: Upgrading International Support. The paper highlights how some governments are using the public health crisis to further curtail democratic activities and provides recommendations for policymakers and civil society organizations to counteract the pandemic's negative impacts on democracy.

\section{Joining efforts to protect democracy in Latin America}

Latin America has been one of the world's worst-hit regions from the pandemic. It has suffered from some of the highest death rates from Covid-19, and widespread lockdowns have contributed to one of the worst economic downturns in decades.

In a joint effort led by International IDEA, the Fundaçao Fernando Henrique Cardoso and the Fundación Democracia y Desarrollo (led by former Chilean President Ricardo Lagos) to commemorate the International Day of Democracy on 15 September, more than 160 leaders from Latin America, including 21 former presidents, signed the joint declaration 'Let Us Take Care of Democracy Lest it Fall Victim to the Pandemic', calling to defend democracy in the region. The document, initiated by renowned pro-democracy organizations, warns that our cherished civil freedoms are threatened by political actors who could use the crisis to illegitimately tighten their grip on power. The declaration was part of the global campaign 'A Call to Defend Democracy', launched in 2020 to raise awareness of the threat to democracy posed by the pandemic.

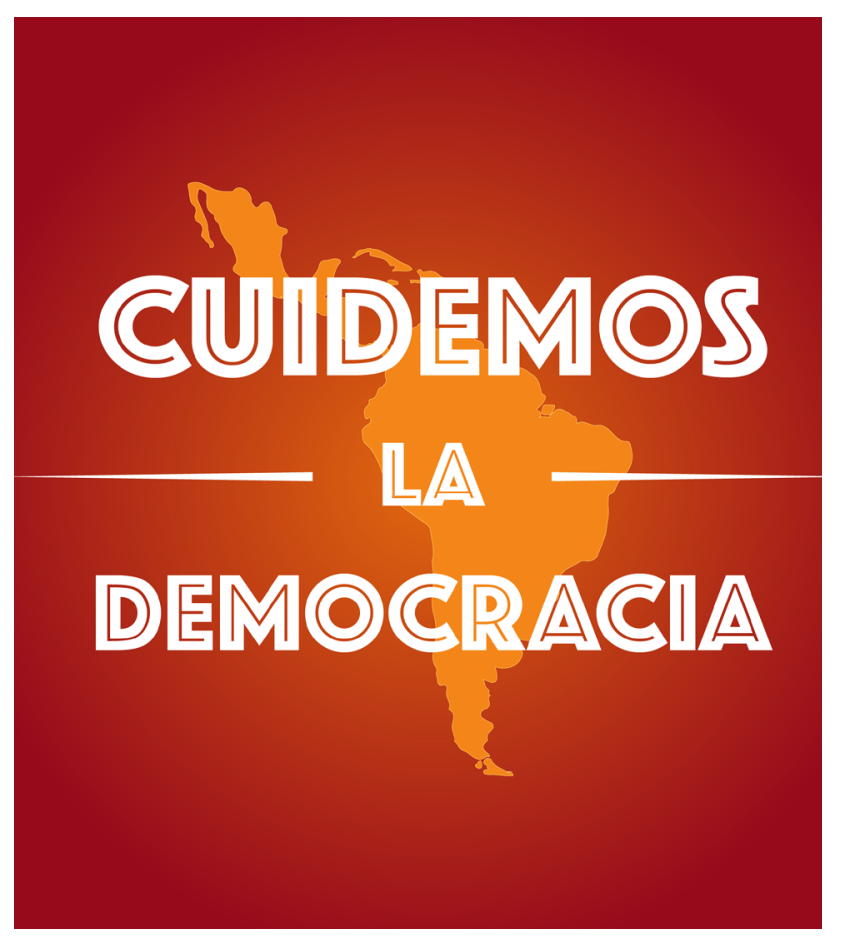

Thanks to the boundary partners with which International IDEA has worked (particularly with important civil society organizations like the Fundação Fernando Henrique Cardoso and the Fundación Democracia y Desarrollo), it was possible to reach many leaders in several countries in the region. The declaration was published in more than 150 media outlets across Latin America and the Caribbean, including prestigious news media such as Clarín, La Nación, Globo, Página Siete, Reforma, La Prensa, El Comercio and El Nacional.

Through this declaration, International IDEA and the co-organizing foundations attracted the commitment of several former presidents from the region, starting with the leaders of the organizations that launched this initiative-former Presidents Fernando Henrique Cardoso and Ricardo Lagos, International IDEA SecretaryGeneral Kevin Casas-Zamora and former Costa Rican President Laura Chinchilla.

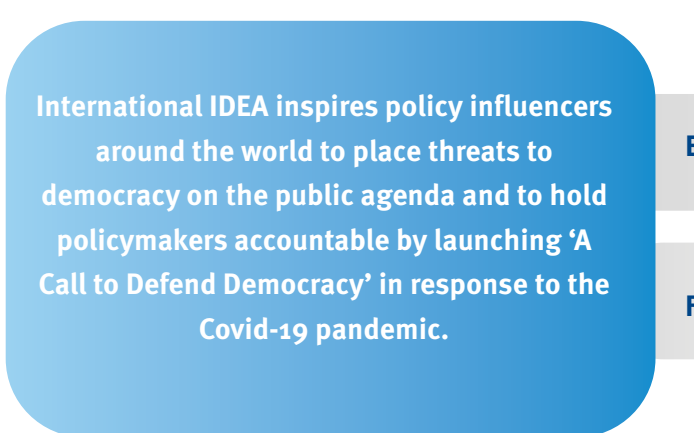

Boundary partners: Policy influencers and policymakers

Funding: Cor 


\section{Highlights}

\section{Elections and Covid-19-Helping authorities make informed decisions}

The Covid-19 pandemic has required a balancing act between protecting public health and preserving public trust in democracy. These difficult choices had to be made and implemented at an unprecedented pace, sometimes under fierce scrutiny. Understanding how others were handling similar situations became an important touchstone.

Electoral authorities urgently needed examples of what alternative or adapted voting arrangements were feasible, and under what conditions; they needed models of how others were handling unprecedented legislative and political consensus-building and public communication challenges. International IDEA needed to take action quickly.

Within the first week of the pandemic, International IDEA quickly developed a multilanguage, multimedia page tracking Covid-19 elections that has attracted over 70,000 page views from 168 countries.

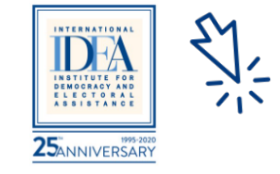

National and Subnational Elections Postponed

Go To
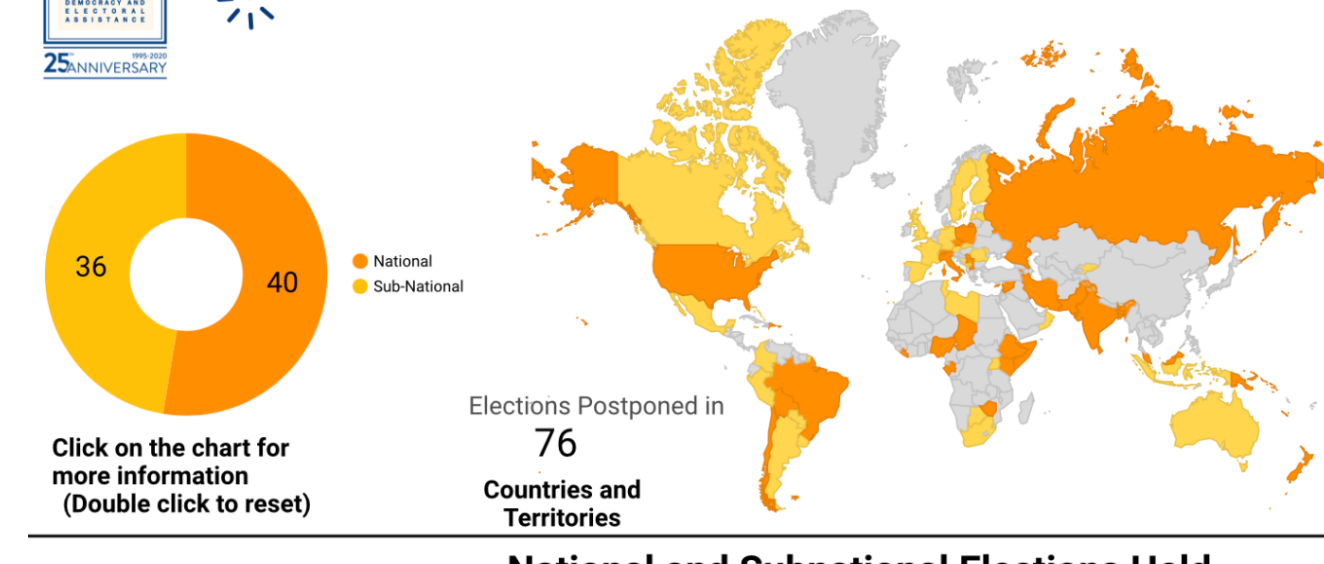

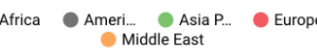

National and Subnational Elections Held
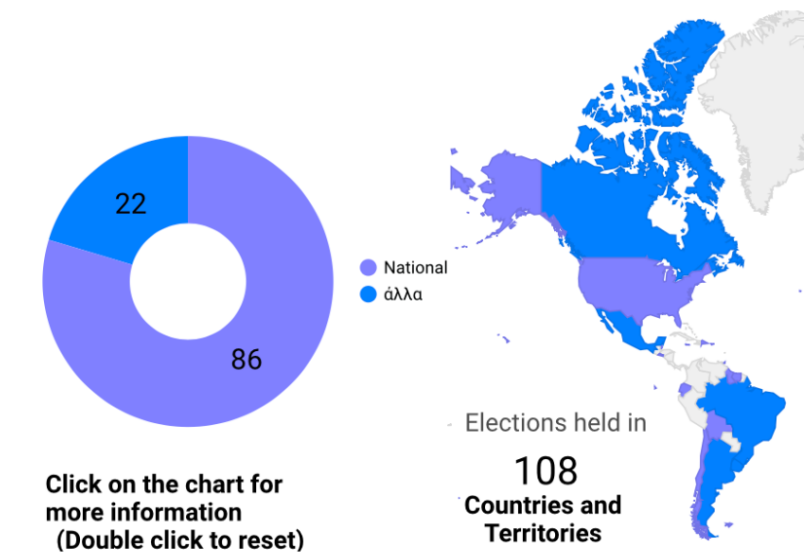
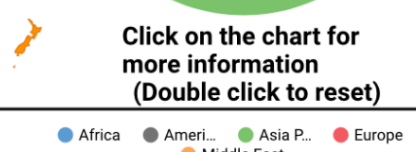

Click on the chart for
more information More information
(Double click to reset) 108
Countries and
Territories

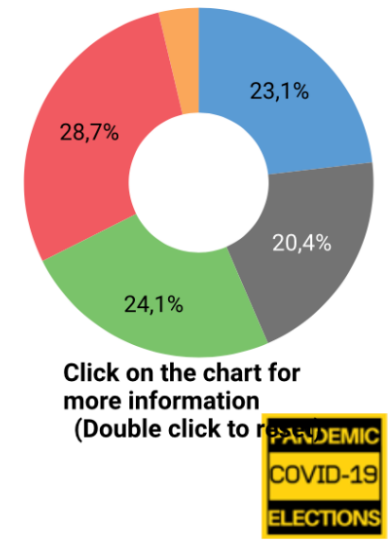

While the intended audience was electoral authorities, the users included over 100 international and nationa media outlets. CNN, The Economist, BBC, Foreign Affairs, and Le Figaro are some of the outlets that cited International IDEA's data and analysis. Technical papers and over 40 pieces of analysis in the form of articles and other written interventions were quickly produced. International IDEA experts made themselves available on webinars, domestic interagency consultations and legislative hearings-including lectures for Latin American, European and Asian electoral management body audiences, testimony to the US Congress, and participation in interagency mechanisms in Norway and the United Kingdom.

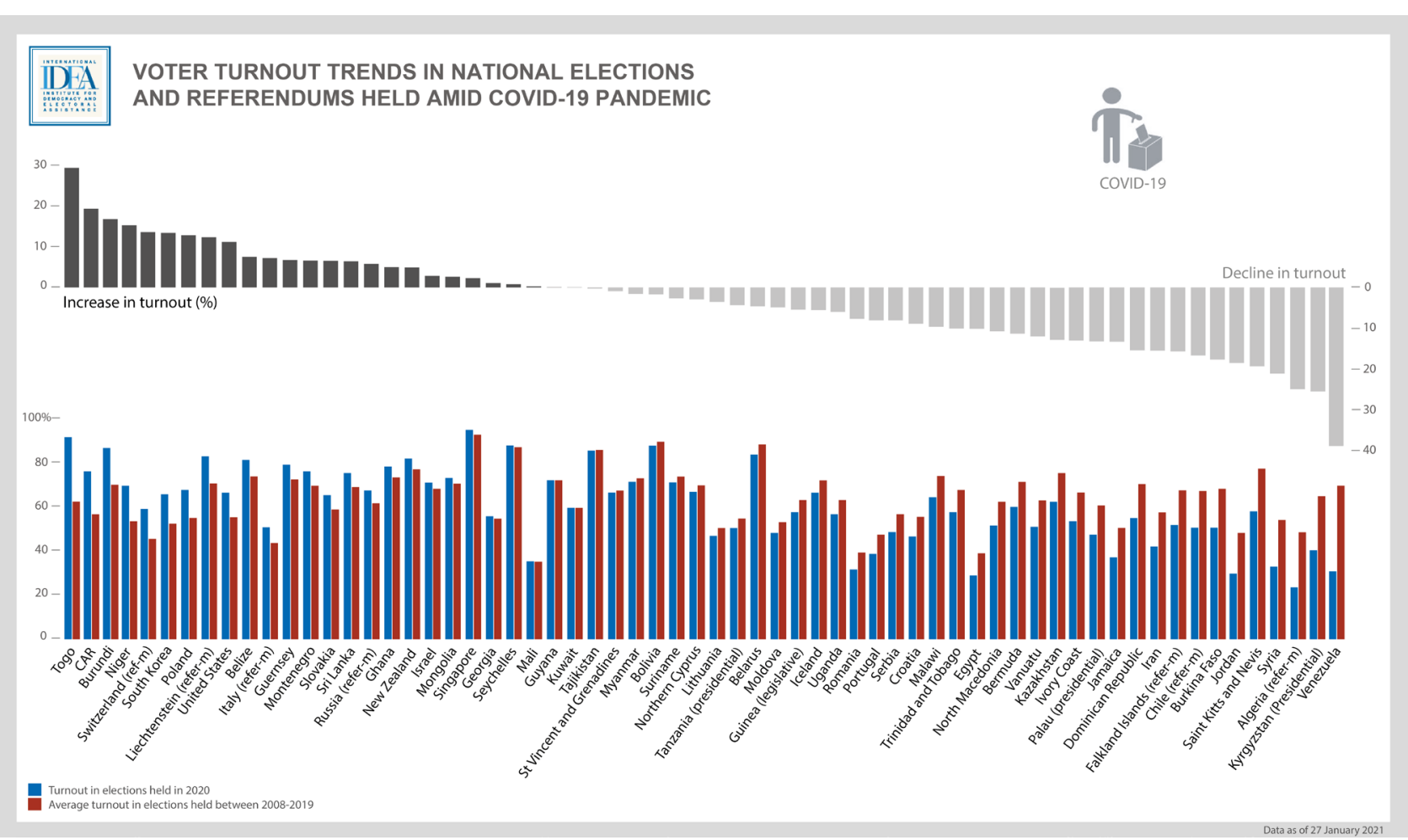

The data continue to inform the Global Monitor, which tracks the overall impact of Covid-19 on the state of democracy and human rights worldwide. Regional and global organizations such as The Commonwealth and the African Union have used International IDEA's research material to develop guiding documents for their constituencies.

By launching a multimedia page with nalysis and technical papers on Covid-19 and elections, International IDEA helps policymakers and electoral management bodies to redesign electoral processes and inspires civil society to hold policymakers accountable.
Policymakers, electoral management Boundary partners: $\mathrm{P}$ icy
bodies, civil society

Funding: Core 


\section{International IDEA's 25th Anniversary}

In 2020, International IDEA celebrated its 25th anniversary by highlighting, throughout the year, its regional and thematic areas of expertise, which were rapidly adapted to support our stakeholders during the Covid-19 pandemic.

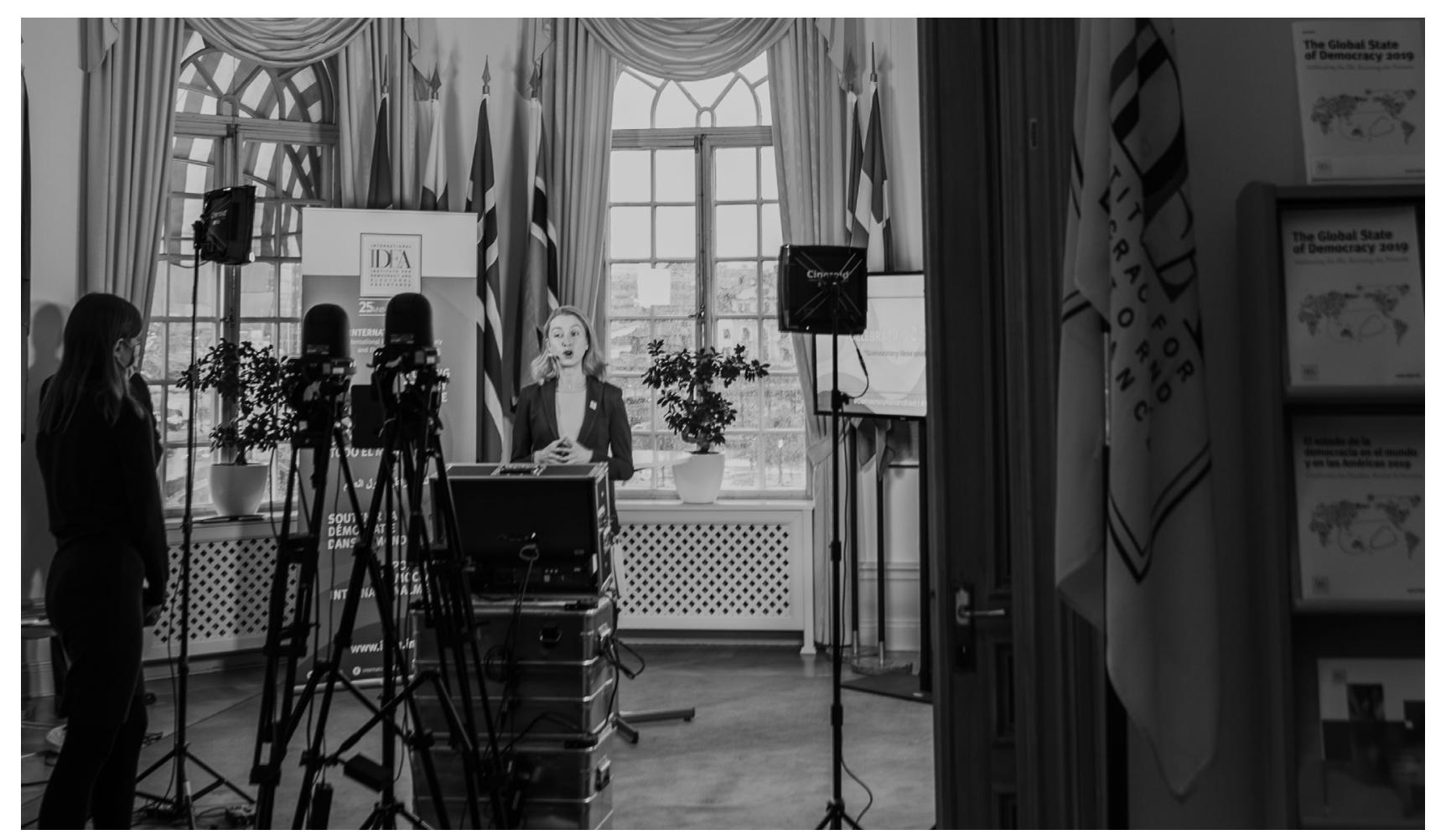

The highlight of our celebration was a global virtual 25-hour conference consisting of 12 webinars organized by International IDEA's regional and country offices. The webinars offered insights and fascinating discussions of the most salient democracy issues around the world such as climate change, populism, technology and inclusive representation.

The conference featured a total of 63 prominent speakers, including heads of state, renowned democracy experts, policymakers as well as representatives from civil society and youth.

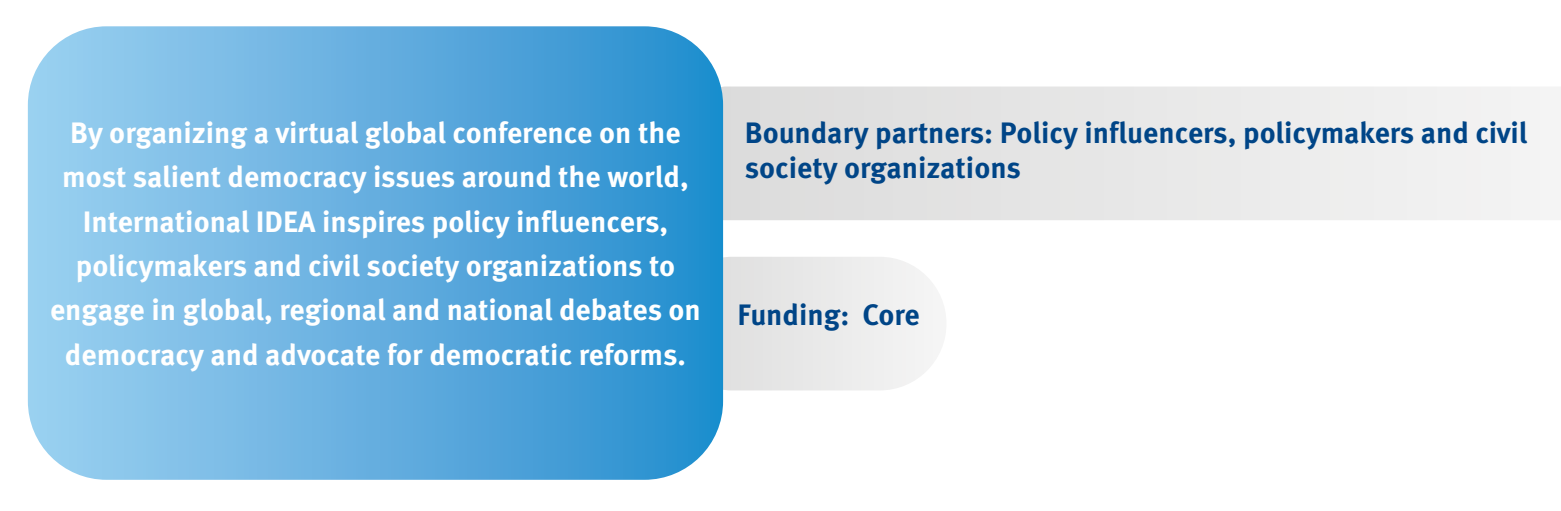

Photo credits: Malin Huusmann
Over 1,700 participants took part in the webinars, and nearly 6,000 people had watched the recordings on YouTube by the beginning of December 2020. International IDEA also reached more than 250,000 impressions on social media (the number of times International IDEA content was displayed in users' social media feeds) during and after the conference.

In addition to celebrating the Institute's achievements during the last 25 years, the conference served as an opportunity to launch a conversation about the future of democracy and the role International IDEA and our partners can play in it.
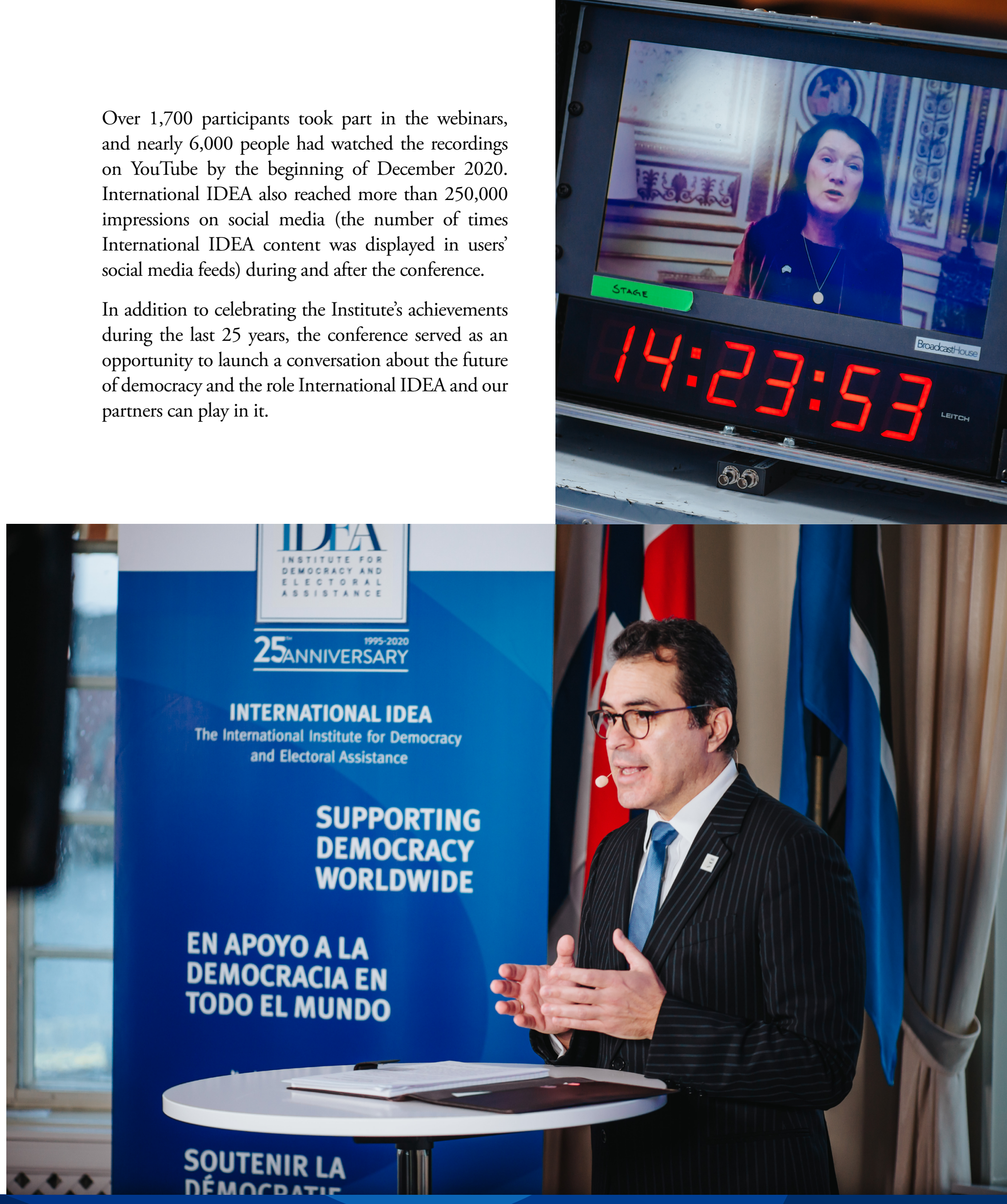

INTERNATIONAL IDEA The international institute for Democracy and Electoral Assistance

\section{SUPPORTING DEMOCRACY WORLDWIDE}

EN APOYO A LA DEMOCRACIA EN TODO EL MUNDO

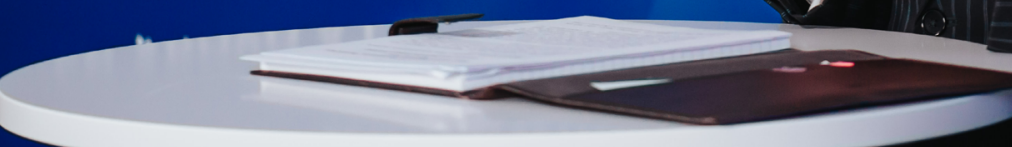

SOUTENIR LA nF́MOCDATIF 


\section{Highlights}

\section{Deepening our collaboration with the host country and 2020 Council of Member States Chair}

Throughout the year, International IDEA has actively worked with the host country and 2020 chair of the Council of Member States, Sweden. The Institute organized several events to support the Drive for Democracy, a Swedish Ministry for Foreign Affairs initiative.

In March, International IDEA arranged a roundtable discussion with female Members of Parliament in Myanmar, together with the Embassy of Sweden Section Office in Yangon. In June, the Embassy of Sweden to the Republic of Korea and International IDEA co-organized a high-level webinar to examine the pandemic's potential consequences for democracy worldwide using the case studies of Australia, the Republic of Korea together with experts from the three countries. As part of Sweden's 'Democracy Talks', International IDEA organized an online event on Filipino Youth's Democratic Participation in collaboration with the Embassy of Sweden to the Philippines in December.

International IDEA's SecretaryGeneral participated in the Swedish Parliament's commemoration of the 75th anniversary of the United Nations (UN), where he spoke about the state of democracy around the world and the need to defend democratic values worldwide. The seminar-which focused on the UN and the protection of democracy, human rights and the rule of law-featured speakers such as Swedish Minister for Foreign Affairs Ann Linde, UN experts and members of the Swedish Parliament.

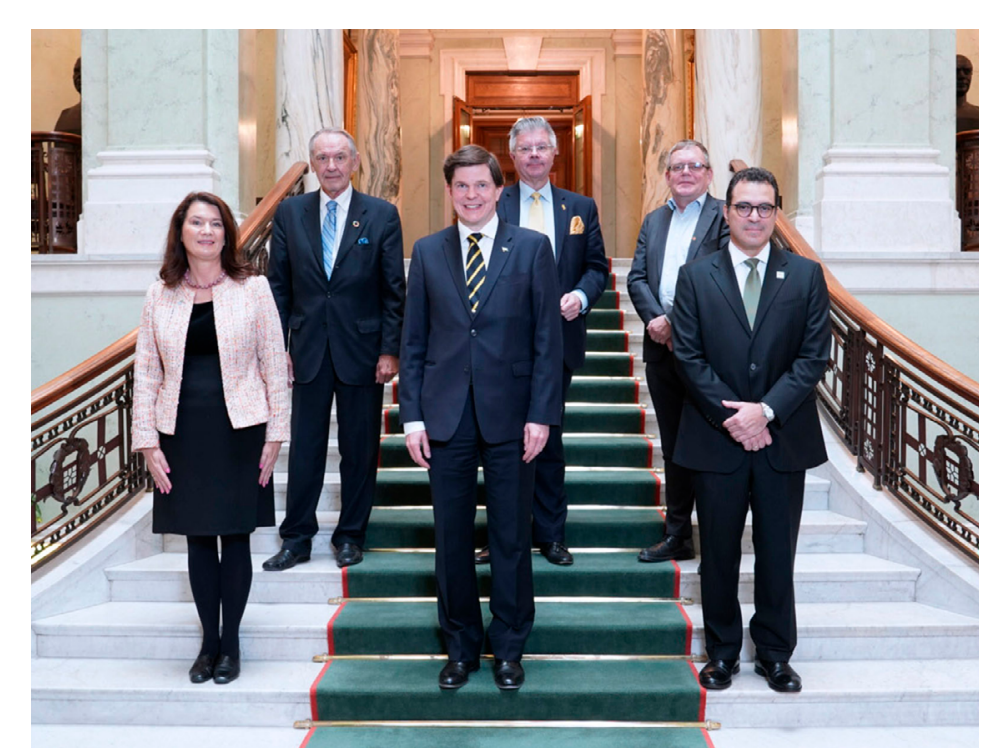

Boundary partners: Policy influencers, policymakers and civil society organizations
By organizing events on democracy in cooperation with the government of Sweden, international IDEA inspires policy influencers, policymakers and civil society organizations to engage in global, regional and national debates on democracy and advocate for democratic reforms.

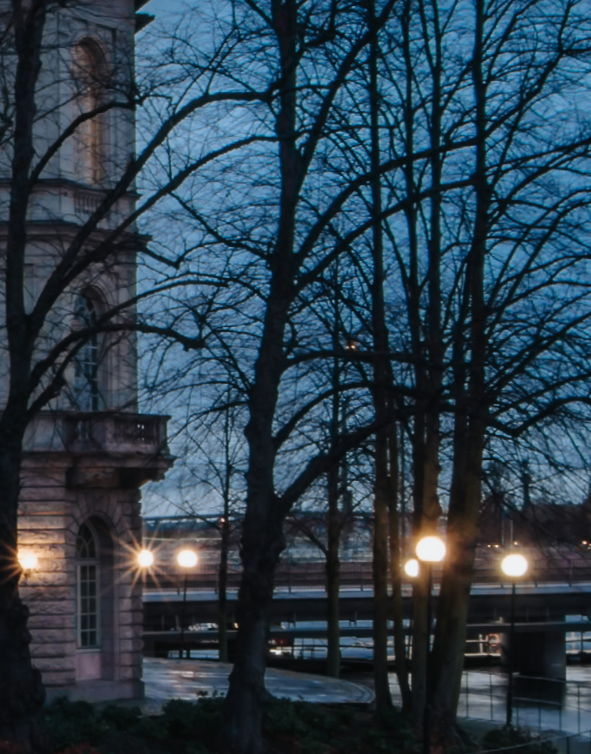




\section{Outcome Stories}


CONSTITUTION-BUILDING PROCESSES

\section{International IDEA supports understanding and analysis of the relationship between constitutions and emergency responses to Covid-19}

Government responses to Covid-19 around the world

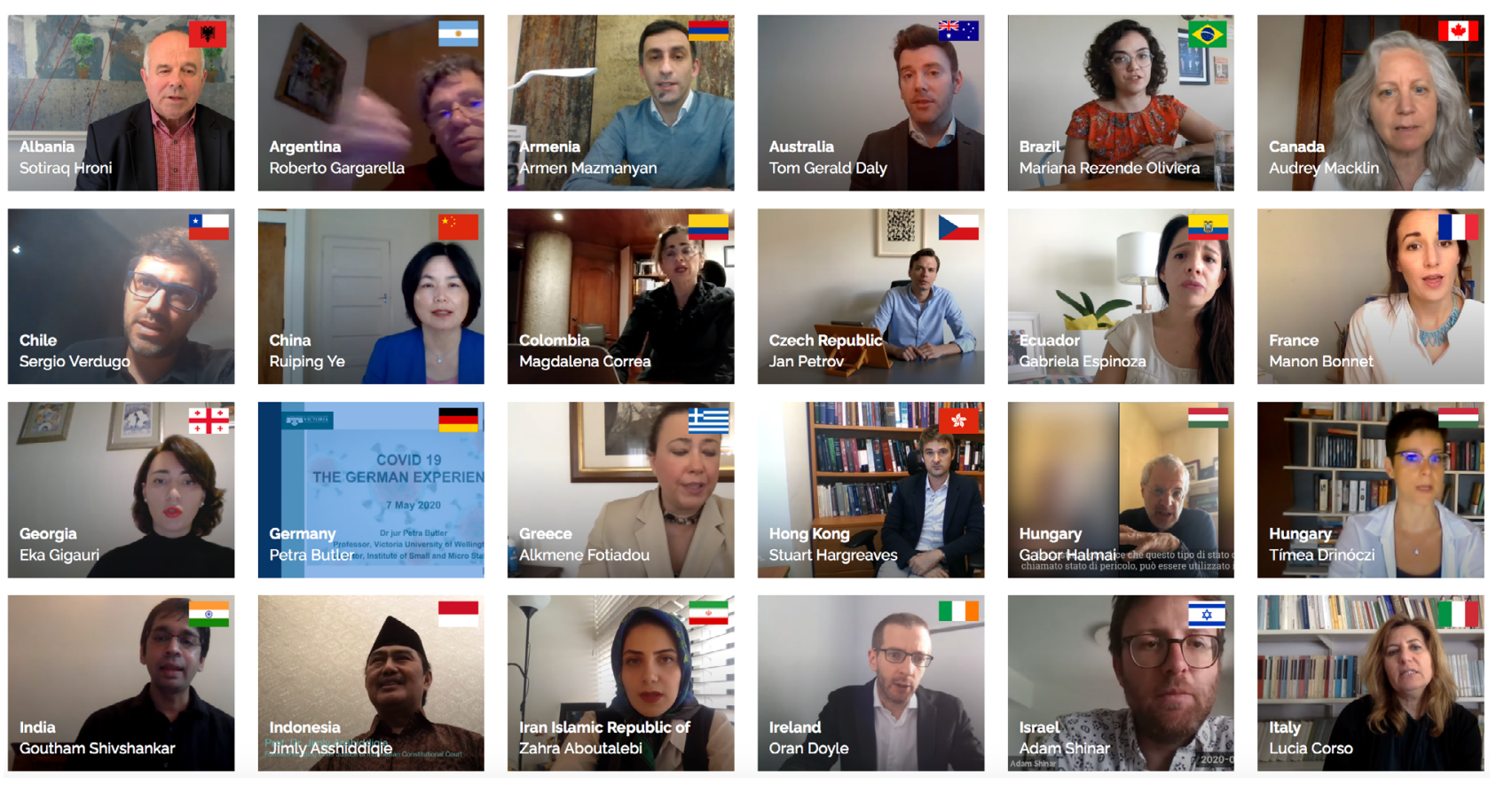

ConstitutionNet.org features a compilation of videos on constitutional/legal responses of governments around the world to the pandemic.

The Covid-19 pandemic in 2020 caused a significant number of states to enact a variety of legal and policy responses to combat the spread of the virus. In many places, this has included declaring a constitutional state of emergency. In response to the challenges presented by the pandemic, International IDEA's Constitution-Building Programme (CBP) worked with its long-standing partner, the United Nations Development Programme (UNDP) to develop a Guidance Note on Covid-19, Emergency Powers and the Protection of Human Rights and the Rule of Law, which was disseminated to UNDP headquarters and field offices in the summer of 2020 .

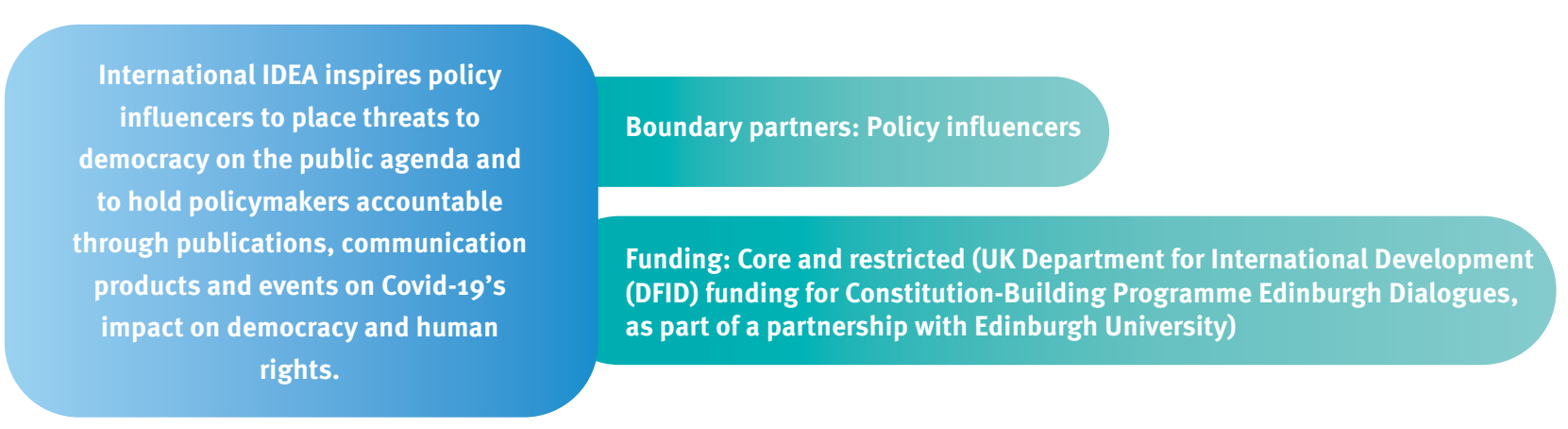

CBP also leveraged its broad network of global constitution-building advisers and implementors to develop and publish a series of 50 videos featuring country-level scholars discussing the constitutional/ legal responses of governments around the world to the Covid-19 pandemic. The project is the result of a partnership between International IDEA, the New Zealand Center for Public Law, and the Center for International and Area Studies at Northwestern University.

Internally, CBP has assisted the Democracy Assessment team in its global and regional Global State of Democracy assessments on Covid-19 and democracy, advising on constitutional and legal emergency framework structures, comparative approaches, and analysing democratic developments and risks.

In December, this focus on Covid-19 continued at the 2020 Edinburgh Dialogues on Post-Conflict Constitution-Building. This DFID-funded dialogue event, implemented in partnership with the University of Edinburgh, brought together scholars and practitioners from conflict-affected countries around the world to examine the nature of legal responses to Covid-19 and the implications for peacebuilding and constitution-building in years to come.

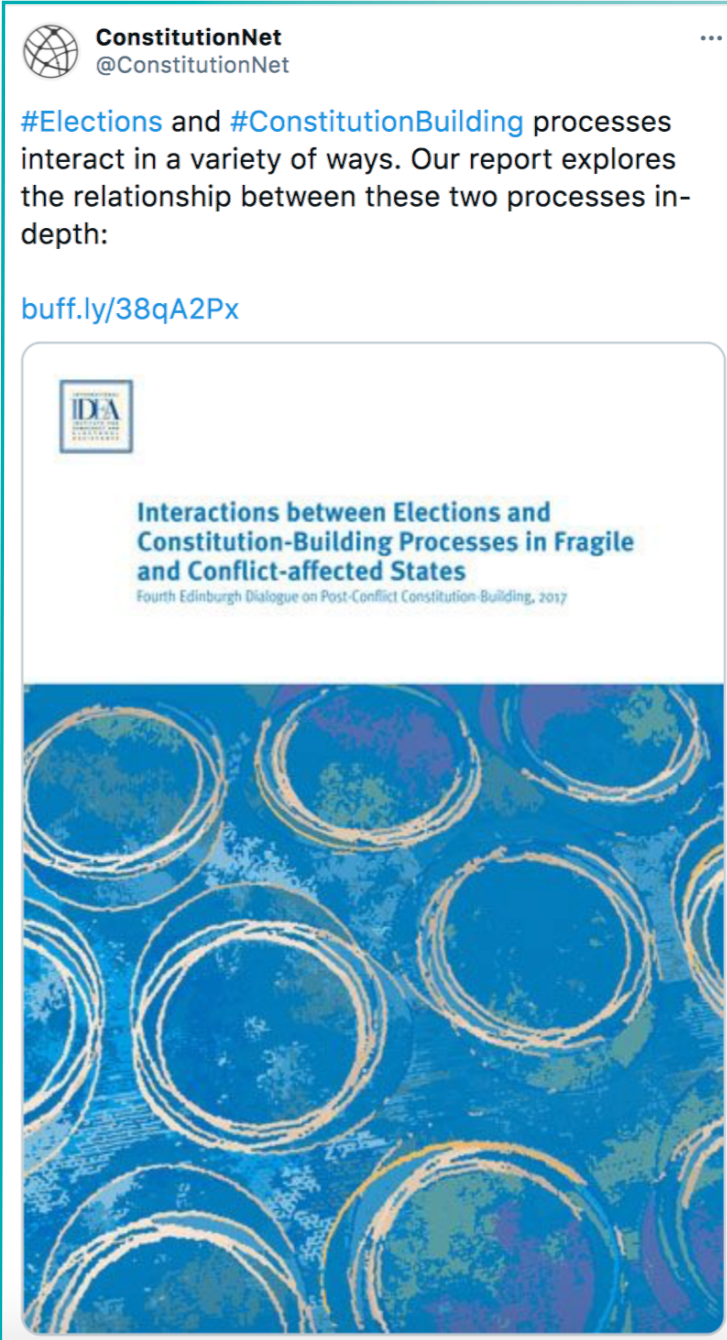


CONSTITUTION-BUILDING PROCESSES

\section{International IDEA supports South Sudan's transition to a peaceful democratic federation}

Enhancing the capacity of women, youth, civil society organizations and political leaders

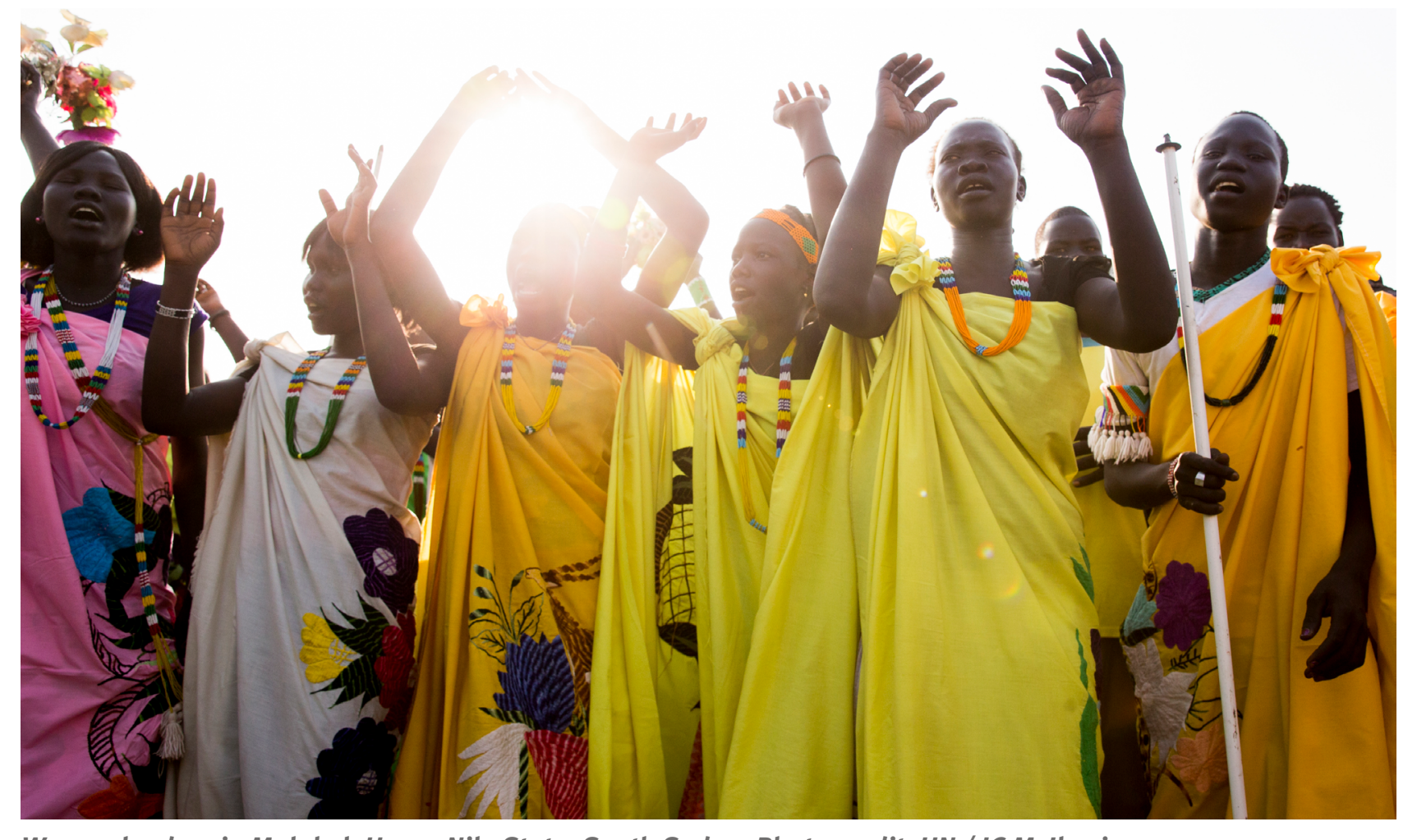

Women leaders in Malakal, Upper Nile State, South Sudan. Photo credit: UN / JC Mcllwaine

South Sudan's ongoing peace process, encapsulated in the 2018 revitalized peace agreement (R-ARCSS), involves several parallel tracks, including a transitional power scheme, agreement on the parameters and mechanisms for federalization, and consensus on a framework for inclusive and participatory constitutionbuilding. Since 2018, International IDEA has been supporting the Sudanese Government and other political groups on constitution-building and federalization.

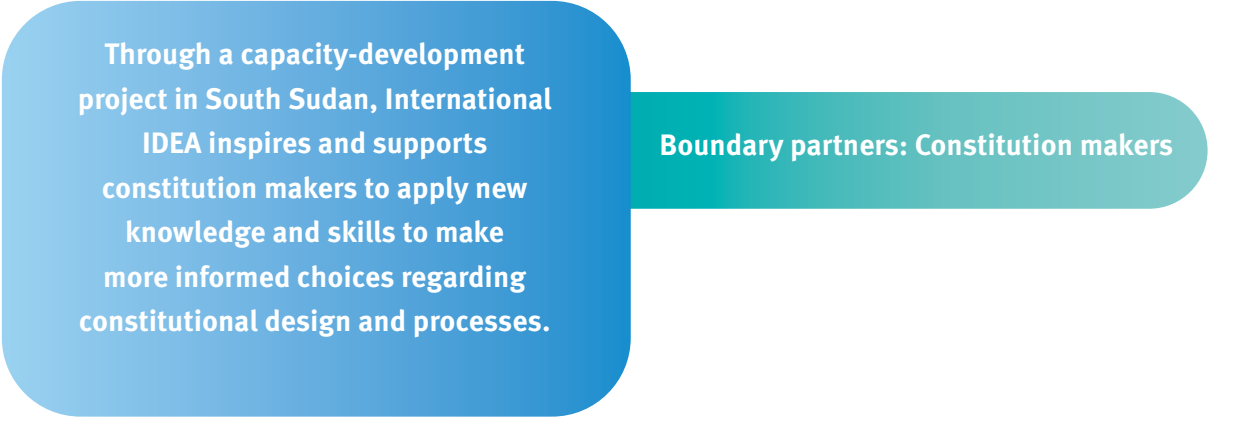

At the request of the Ministry of Federal Affairs and critical continental and international organizations, in 2020 International IDEA's Africa and West Asia and Constitution-Building units provided technical input to preparations for the constitution-building process. A consultative workshop organized by International IDEA provided crucial inputs that allowed the ministry to present and refine a policy framework to promote wide consultations and interaction on federalism among stakeholders in the country's constitution-building process.

International IDEA also supported the establishment of a Constitution-Building Working Group that brings together the UN Mission in South Sudan, the UN Development Programme, UN Women, the Reconstituted Joint Monitoring and Evaluation Commission (R-JMEC), Intergovernmental Authority on Development, African Union Representative to South Sudan and other key international actors. Thi partnership has allowed International IDEA to support consultative workshops to enhance the capacity of women, youth, civil society organizations and political leaders to prepare for engaging in the constitutionbuilding process and interacting with each other.

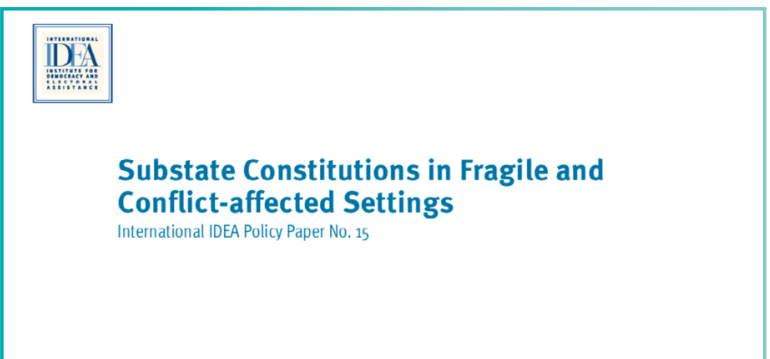

International IDEA and its partners are also working with R-JMEC and the Max Planck Foundation on convening a consultative workshop on constitutionmaking for the principal political leaders as stipulated in the Revitalized Agreement for the Resolution of the Conflict in South Sudan. The partnership has established a new way of working that allows International IDEA to combine its thematic expertise with our partners' presence on the ground to work around the travel restrictions imposed by the Covid-19 pandemic.

The recognition of International IDEA's expertise has also attracted funding, including from the UK Government, to strengthen its support for women leaders in the expected constitution-making process. 
CONSTITUTION-BUILDING PROCESSES

\section{The Melbourne Forum: regional community of experts consolidated and regional experience on constitution- building elevated}

Peer-to-peer engagement and experience sharing on constitution-building themes of global importance

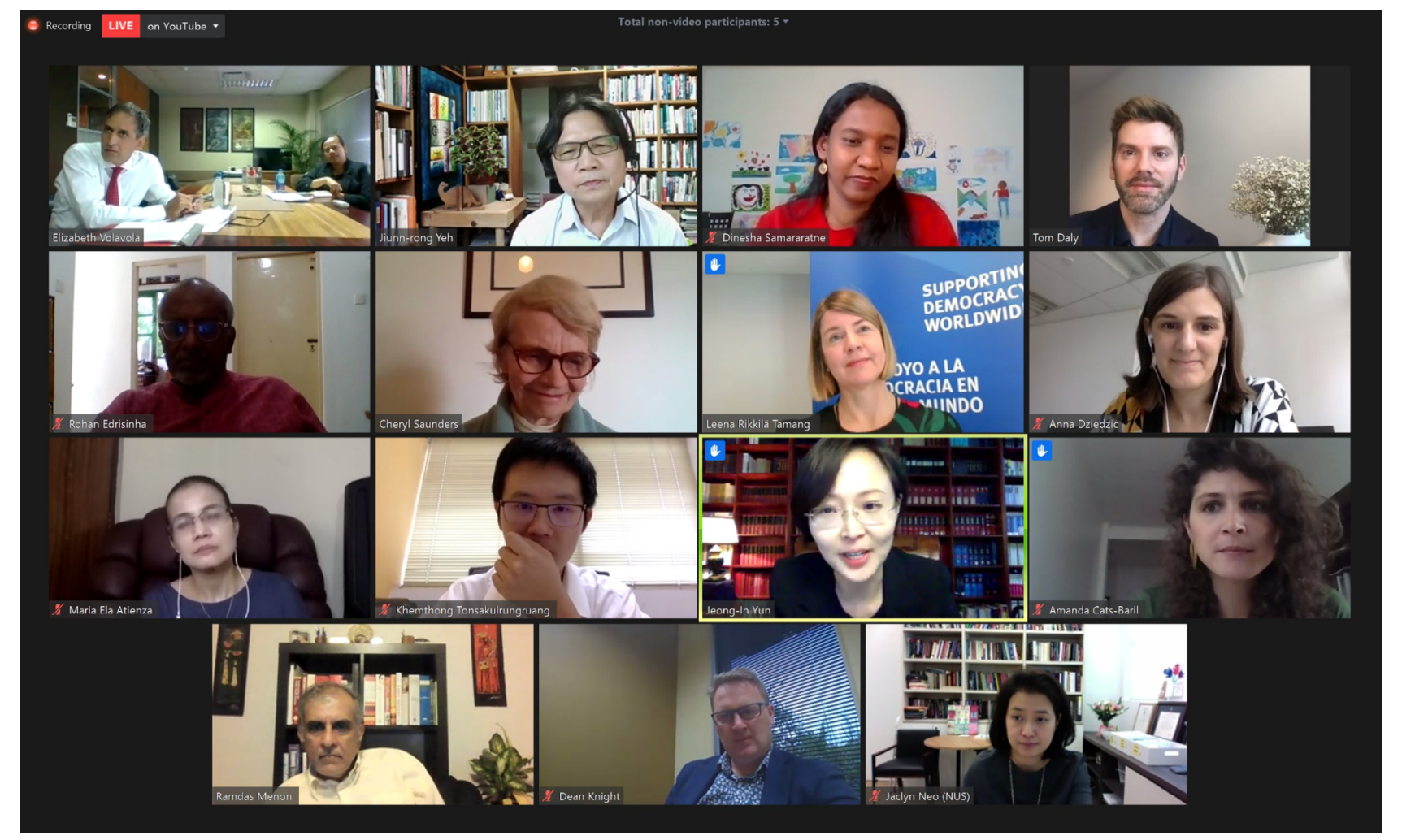

The Melbourne Forum 2020 took place virtually, featuring four online seminars on Representation in Democracies During Emergencies throughout September 2020.

The Melbourne Forum on Constitution-Building in Asia and the Pacific started in 2016 to fill a need for direct peer-to-peer engagement and experience sharing among practitioners and scholars in the region on constitution-building themes of global importance. The Melbourne Forum began as an annual event organized jointly by International IDEA and the Constitution Transformation Network at Melbourne Law School, but has matured into a community of experts who seek advice and support from one another.

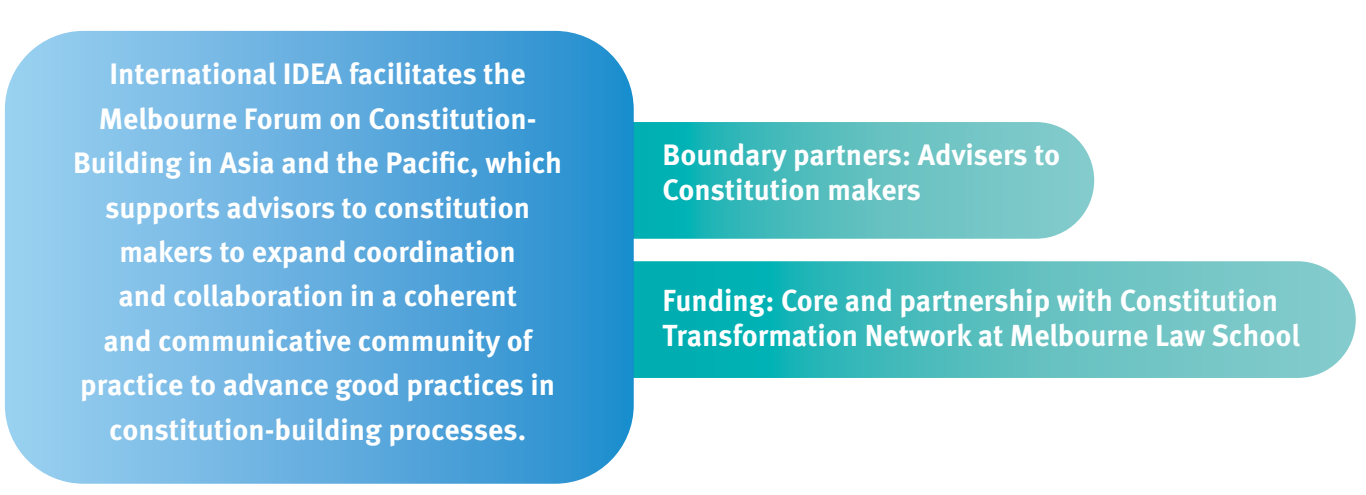

The Melbourne Forum has established itself as a leading network of experts; it has successfully helped to elevate the perspectives, knowledge and experience of Asia and the Pacific in all its diversity and complexity.

"The Melbourne Forum is a good opportunity for scholars and practitioners on constitutional and politica reform to compare the experiences of different countries and learn lessons from each other. Because it is held regularly, the Forum can build a network of people that monitor constitutional issues, reforms, and challenges to democracy in individual countries in the Asia-Pacific and the region. The Forum can potentially generate research projects and more policy and action recommendations for constitutional and other reforms and safeguarding of democracy in individual countries and the region."

- Dr Maria Ela Atienza of the University of the Philippines

Some of these lessons have been captured and disseminated through a series of Constitutional INSIGHT Briefs covering a range of topics from the participation of ex-combatants in constitution-building processes to asymmetrical territorial arrangements in decentralized states.

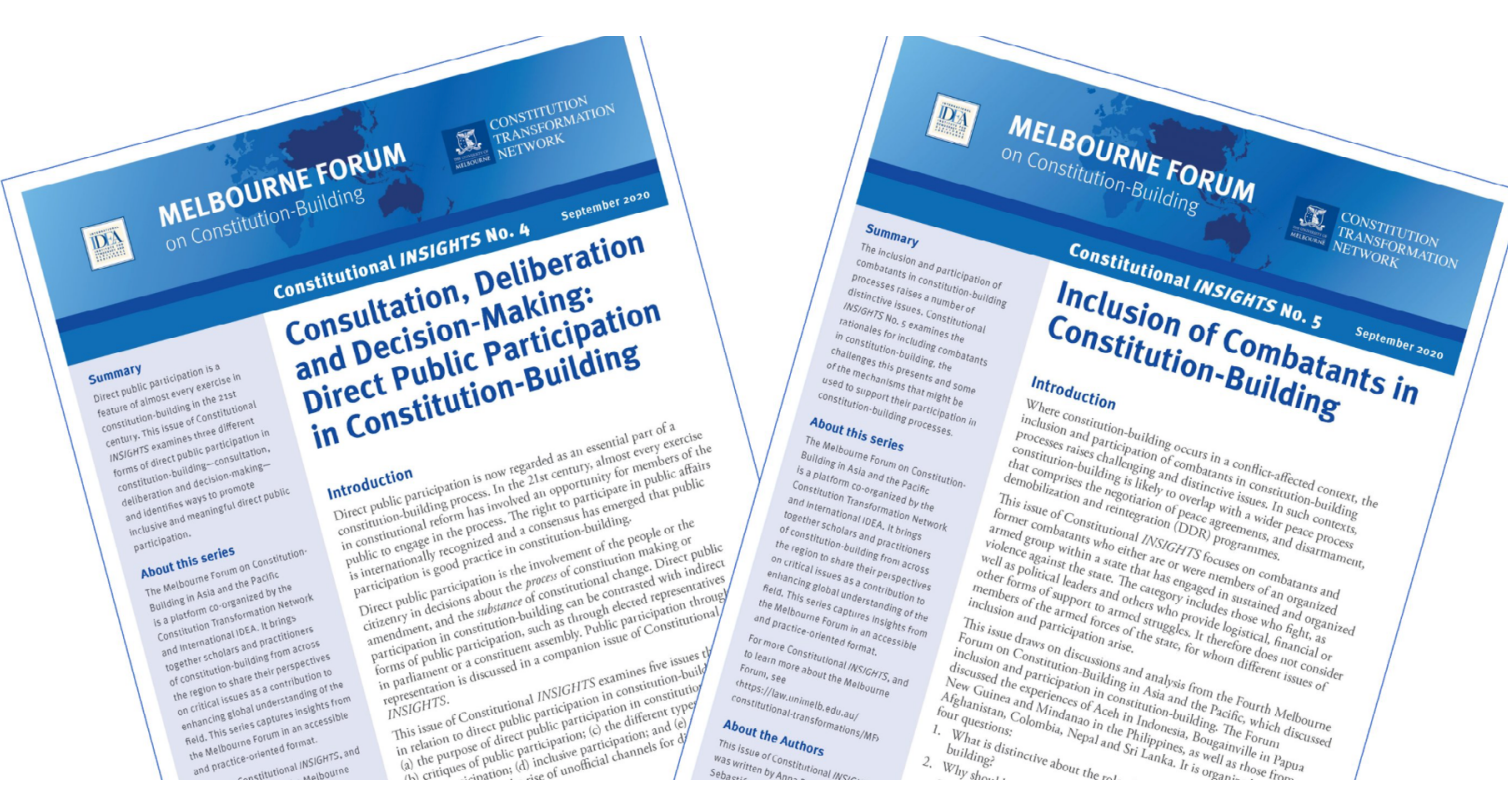


CONSTITUTION-BUILDING PROCESSES

\section{MyConstitution enables ethnic armed organizations to advocate positions on federalism}

Helping ethnic states draft their own constitutions

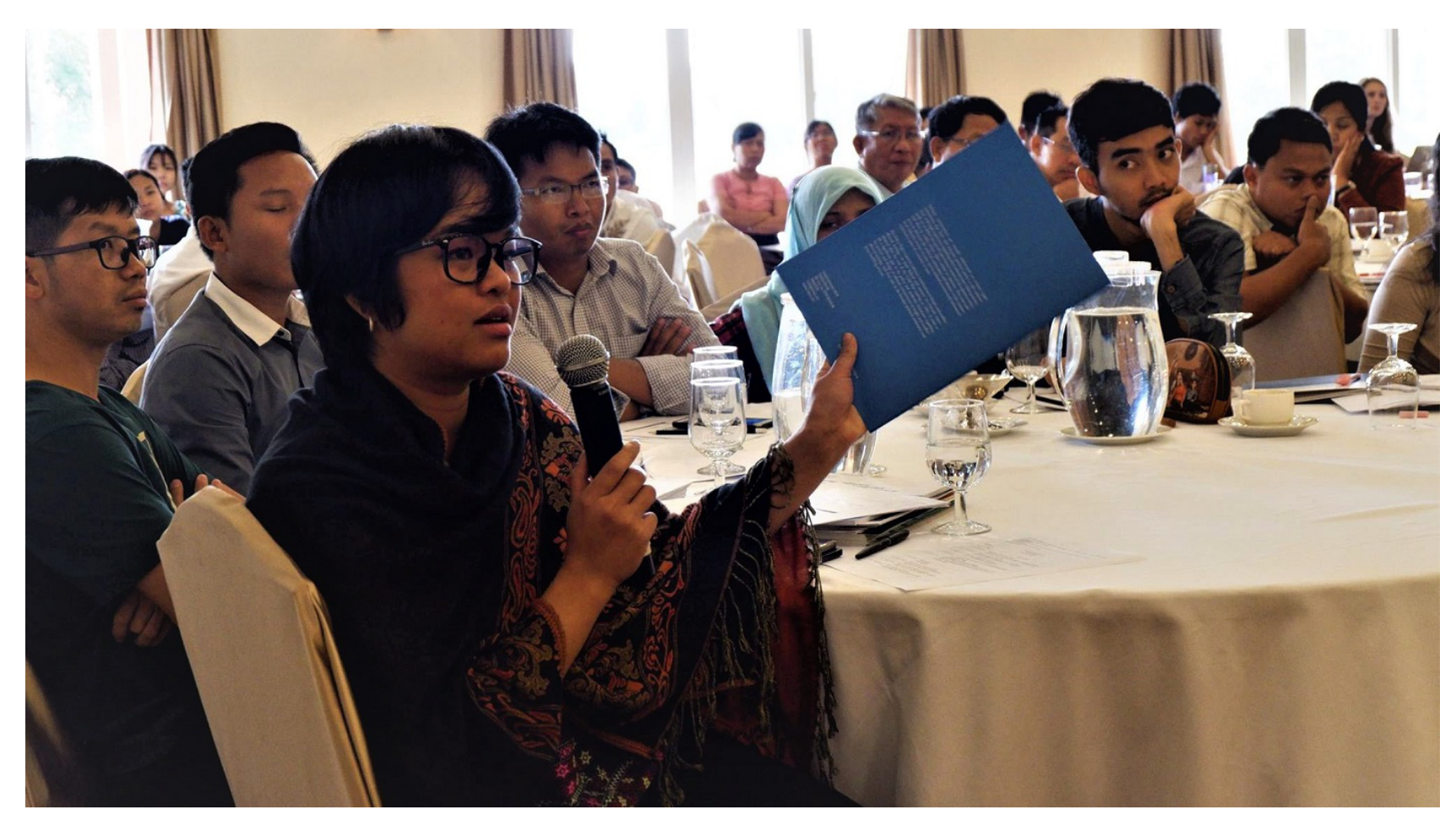

Photo credit: International IDEA (archive image)

For decades, ethnic armed organizations (EAOs) in Myanmar have fought for increased autonomy and sometimes independence. To concretize this aspiration, a key demand in ongoing peace negotiations has been giving ethnic states the right to draft their own constitutions. EAOs have long perceived that substate constitutions would allow them to expand their territorial autonomy vis-à-vis central state institutions.

Building on International IDEA's research, the Constitution-Building Programme, in partnership with the MyConstitution project, began engaging with EAOs and other state-level stakeholders in Myanmar.

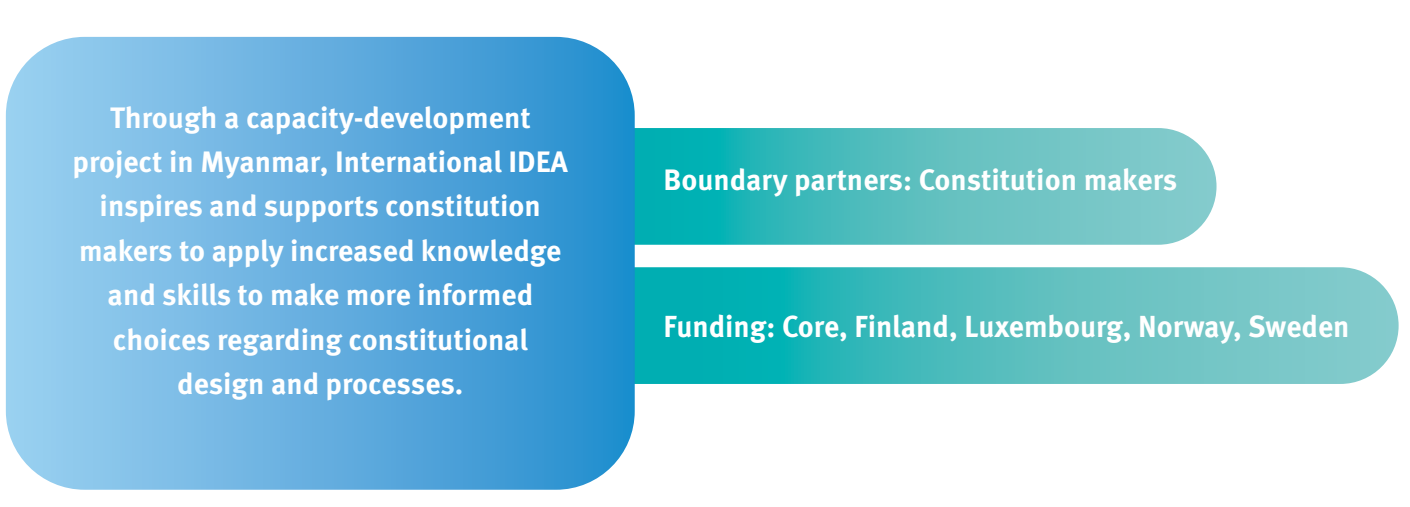

This engagement has transformed the relationships between the actors in the constitution-building process by changing the tone of the negotiations and the content of the narrative on substate constitutions. By 2020, many EAO representatives recognized the subordinate nature of substate constitutions vis-à-vis the central state constitution and are ready to start negotiating a constitutional amendment that would give state-level actors more space to draft meaningful substate constitutions.

'Because of MyConstitution's webinars, I am now more confident to talk about federal issues in the peace negotiation table. This gives me courage', said Saw Mra Raza Lin, Deputy Leader of the Peace Commission for the Arakan Liberation Party and secretary member of the Union Peace Dialogue Joint Committee (UPDJC), a peace negotiator who has actively participated in the six webinars.

She stated that the webinars also support her role in the peace negotiation process: as a woman actor, it is very difficult to get space in the maledominated culture, but the knowledge from the webinars has equipped her to contribute more to the development of a political framework and other UPDJC-related tasks.

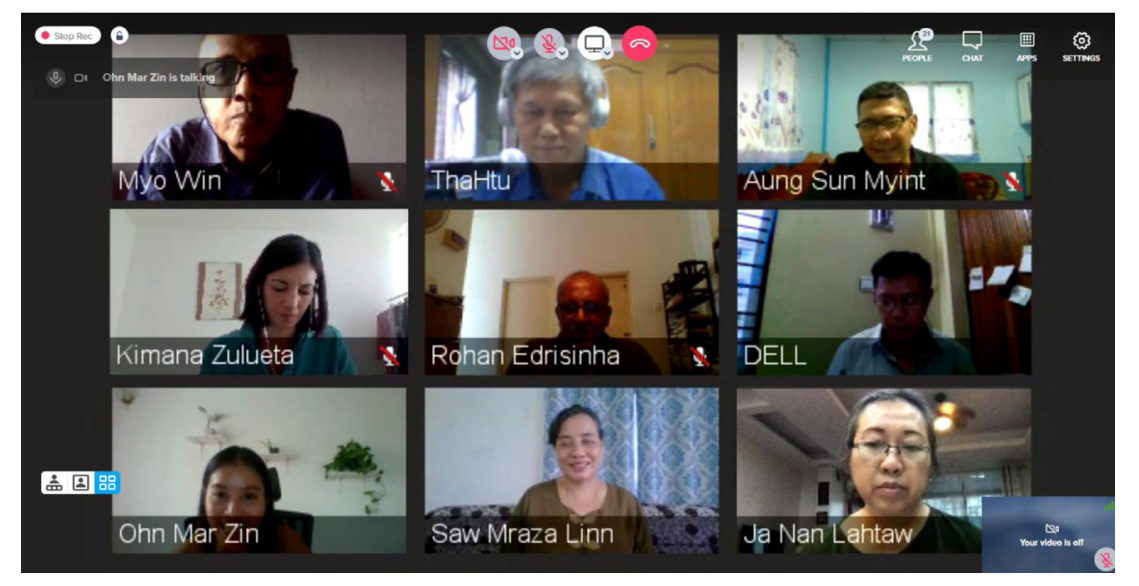

"Because of MyConstitution's webinars, I am now more confident to talk about federal issues in the peace negotiation table. This gives me courage."

- Saw Mra Raza Lin, Deputy Leader of the Peace Commission for the Arakan Liberation Party and secretary member of the Union Peace Dialogue Joint Committee (UPDJC) 
CONSTITUTION-BUILDING PROCESSES

\section{International IDEA's constitution-building expertise supports Armenia's State Constitutional Reform Commission}

Providing comparative analysis and advice on issues related to constitutional design and judicial review processes

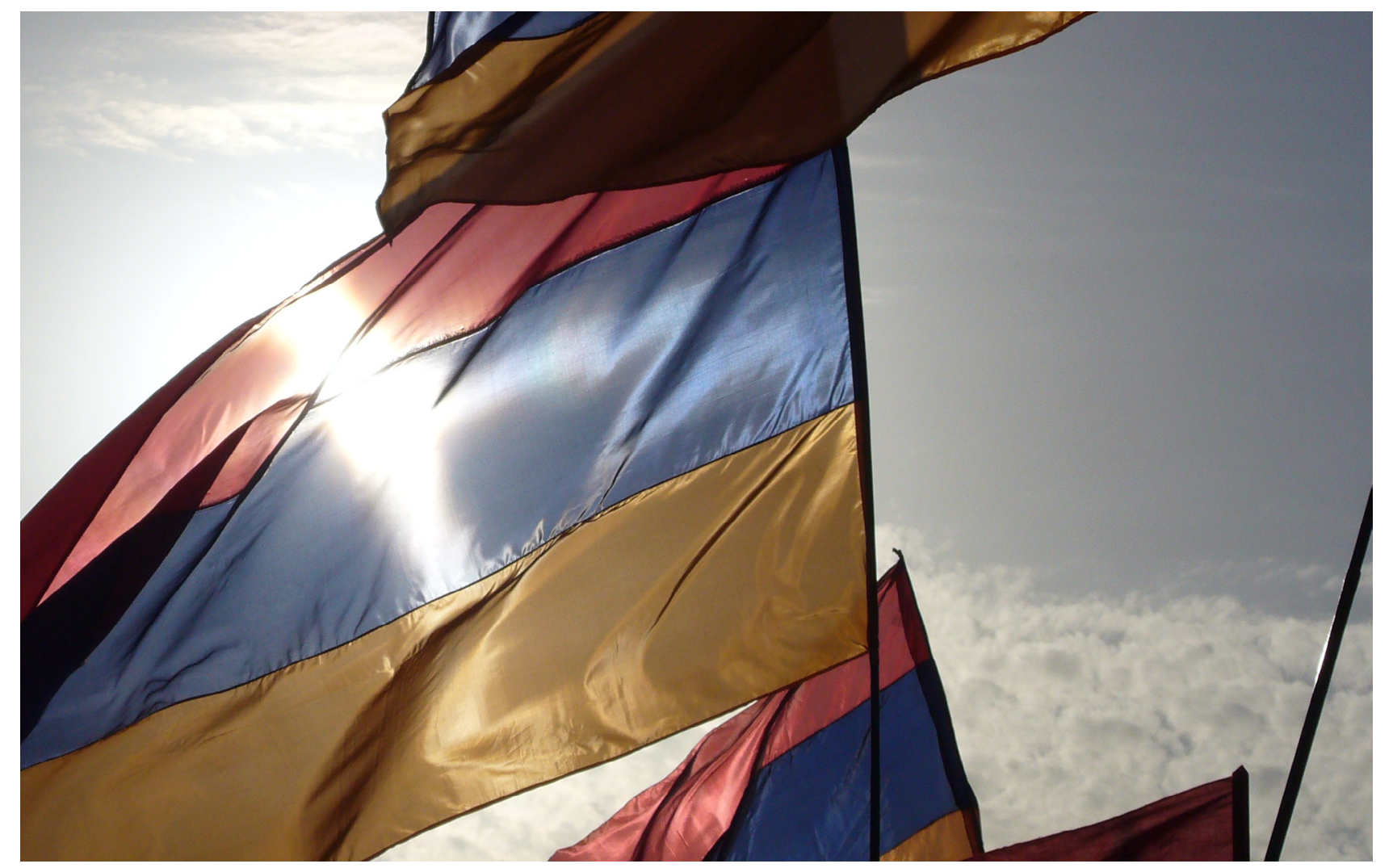

Photo credit: Harout Arabian / Flickr

In late 2019, in the wake of a popular democratic uprising that brought into power Armenia's current Prime Minister Nikol Pashinyan and his reformist government, the country launched a constitutional reform process.

The reform aims to affect a broad range of changes in the country's judicial and oversight bodies. Recognizing International IDEA's global expertise and experience in supporting constitution makers

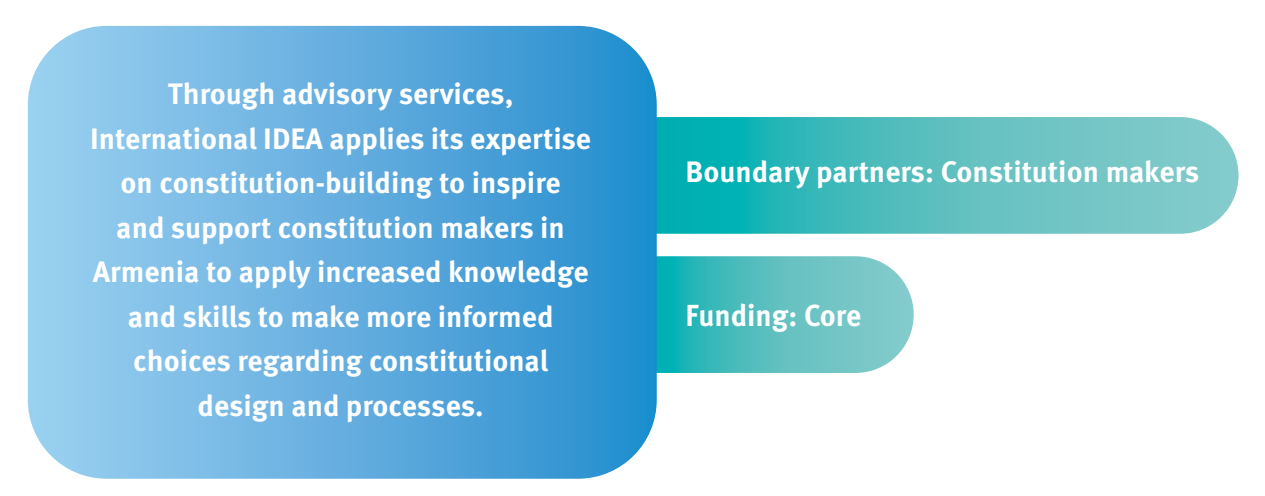

across the globe, Armenia's State Constitutional Reform Commission invited the Institute to provide tailored comparative constitutional expertise to the commission throughout its areas of work.

Over the course of 2020, the Institute combined its in-house experts and external network of international constitution-making advisors to provide thematic expertise to the Constitutional Reform Commission. These advisors supported the commission with comparative analysis and advice on issues related to constitutional design and judicial review processes, constitutional amendment procedures and other issues. International IDEA included comparative practices by involving constitutional law practitioners from other Eastern European countries. The work came to an abrupt halt in September when fighting broke out with neighbouring Azerbaijan over Nagorno-Karabakh.

The assistance is expected to continue once the commission resumes its work. However, the success of the constitutional reform will greatly depend on the result of the ongoing domestic political turbulence, which started after the hostilities ended.

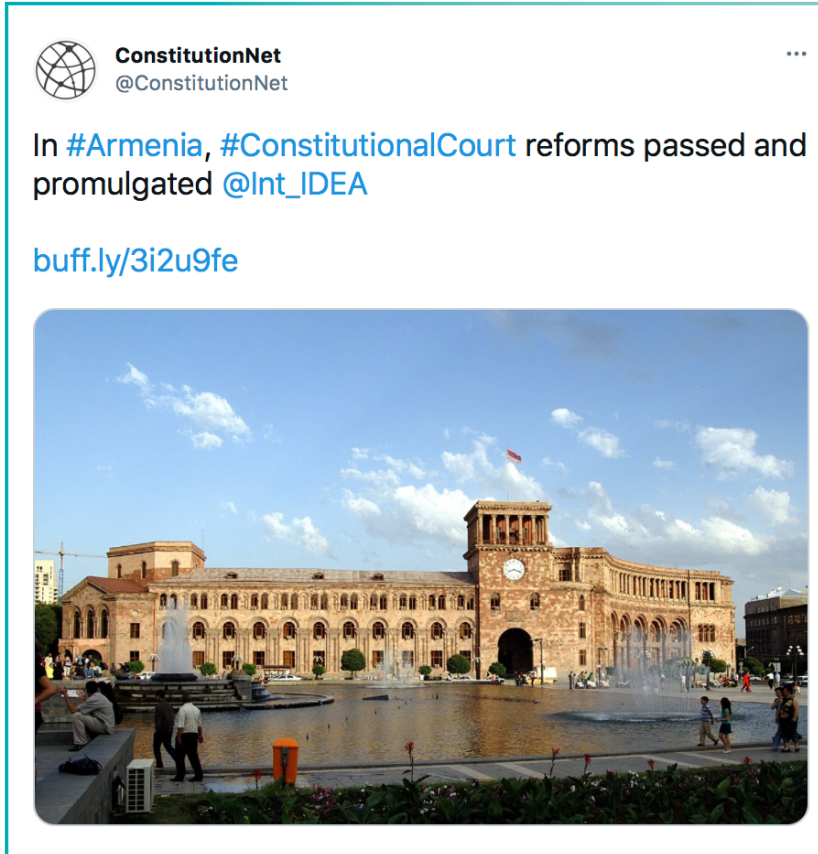




\section{Implementing a framework for developing internal gender policies for electoral management bodies}

Advocacy for gender-sensitive practices to promote public participation in electoral processes

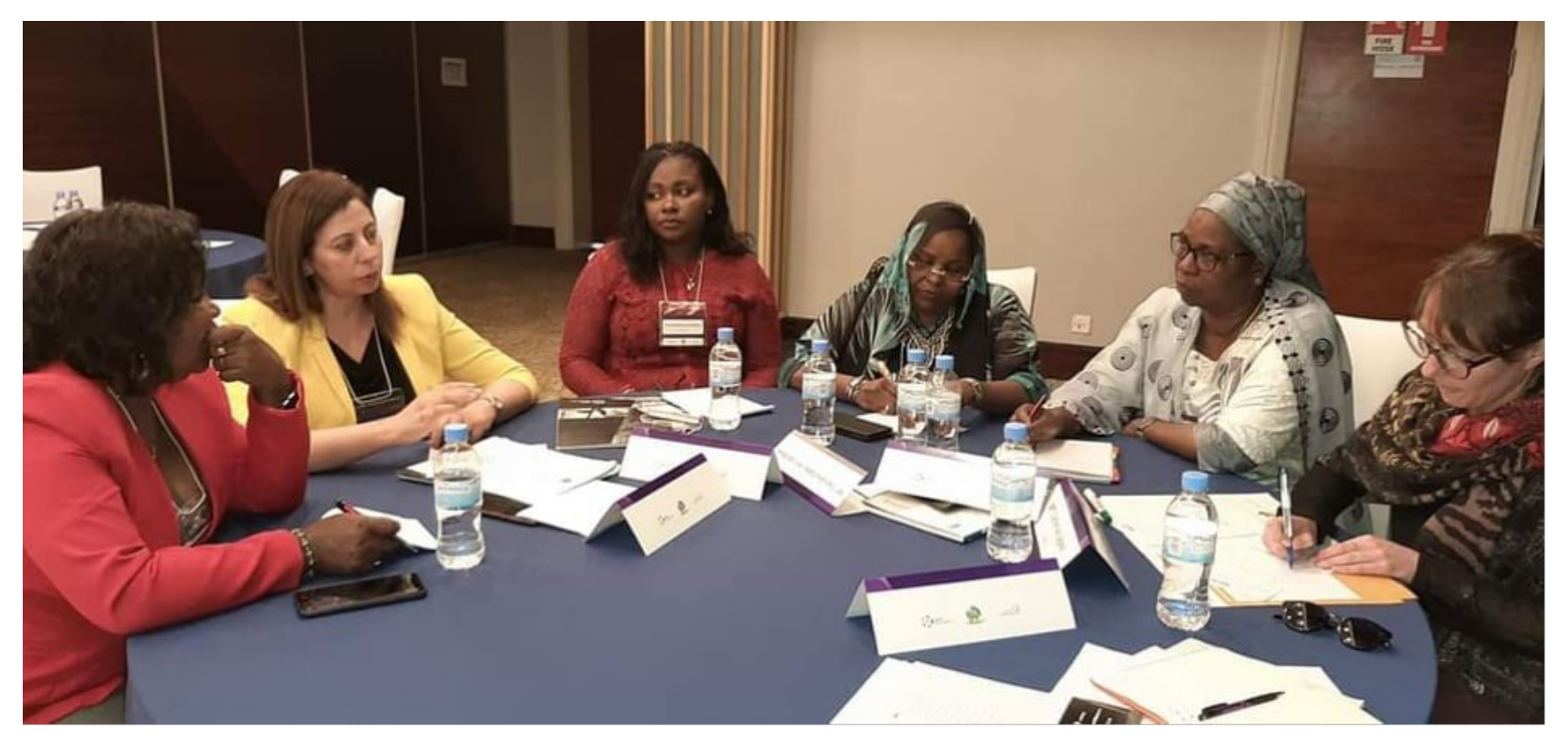

During the launch of RECEF, the Women's Forum with the participation of International IDEA, held in November 2019 in Kigali. Photo credit: International IDEA

'When an EMB disseminates and conveys information that takes into account gender-sensitive perspectives that are in line with its internal gender policy, it delivers the public a message about the importance of striving for gender equality and thus has the potential to influence the media's reporting on electoral issues in gender-sensitive ways', states Rumbidzai Kandawasvika-Nhundu, Senior Adviser, Democracy and Inclusion at International IDEA.

However, few electoral management bodies (EMBs) deliver this message. No Arab countries currently have a woman chairing an EMB. Only Iraq has a female executive director. In sub-Saharan francophone countries, only four women lead an EMB. Trends in women's representation have improved, but it is still below equity expectations.

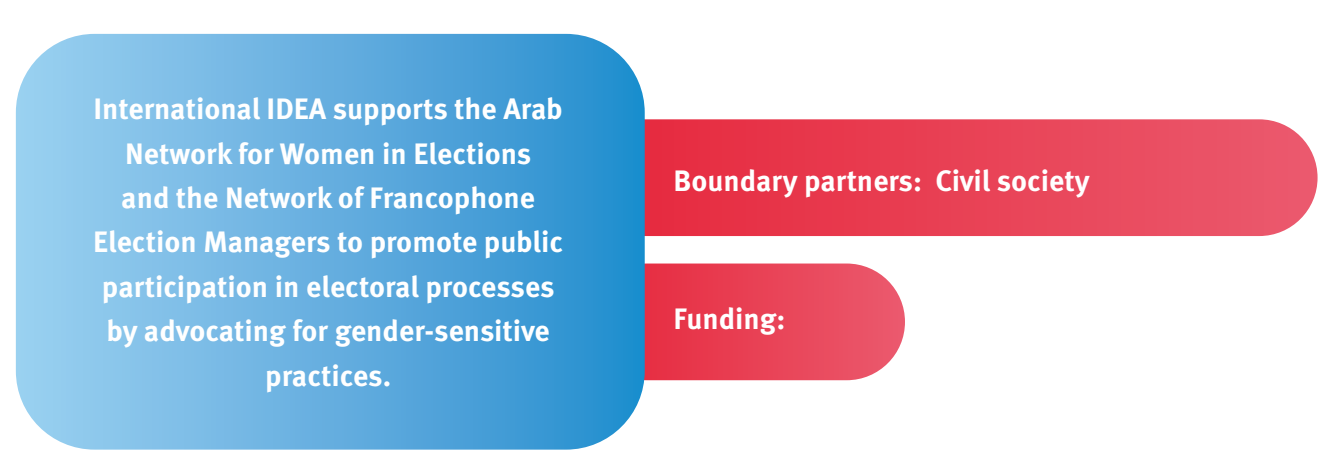

As institutions that disseminate democratic values, EMBs often adopt measures to strengthen women's participation in the registration and voting phases and in their awareness-raising activities. While some EMBs have established gender units, few EMBs have succeeded in establishing sustainable and mainstreamed gender practices. National efforts seem to be insufficient, especially when a country's social and cultural context is resistant. Furthermore, the effort to promote women's participation in a country may be more effective if it is led by an institution that leads by example and is considered a role model, such as an EMB.

Over the years, the Electoral Processes (EP) and Africa and West Asia (AWA) teams have established strong partnerships in the region. International IDEA has a partnership with the women's forum of the Network of Francophone Election Managers, Réseau des compétences électorales francophones (RECEF) - Women's Forum, and has actively participated in the launch of the Arab Network for Women in Elections.

To help decision-makers adopt a sustainable gender strategy, the EP and AWA teams partnered with RECEF and the Arab Network for Women in Elections. The EP and AWA teams are also supporting efforts to advocate a gender approach within EMBs members of both networks.

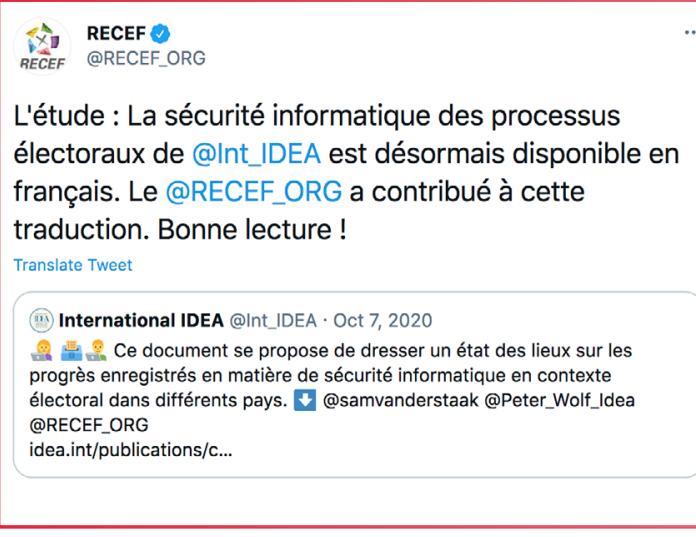

\section{الشبكة العربية للمرأة في الانتخابات}

Ms. Emna Zghonda introducing the manual on longterm election observation from gender perspective by @Int_IDEA, which can be used by civil society organisations and others \#Drive4WomenParticipation \#womeninpolitics \#womeninelections

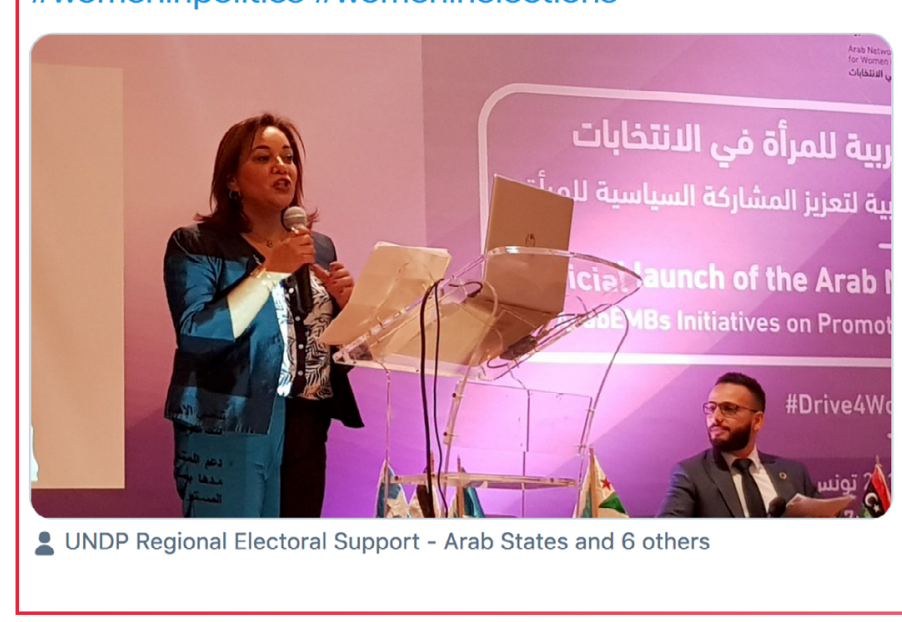




\section{Assisting European electoral commissions handle Covid-19 through special voting arrangements}

New research maps which countries allow what types of SVAs in Europe

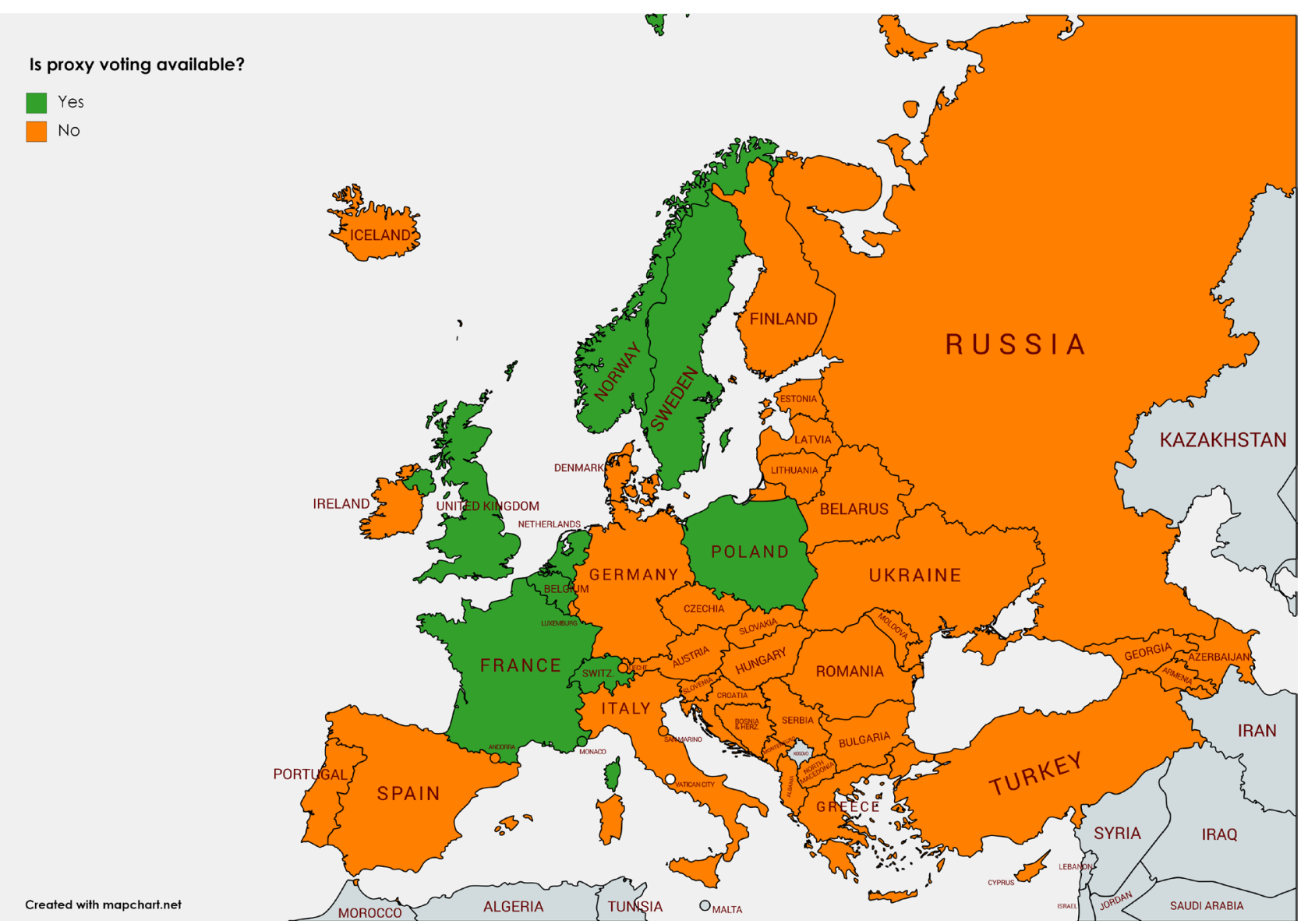

The health risks associated with in-person voting during Covid-19 have increased the popularity of special voting arrangements (SVAs) such as postal voting, early voting and mobile voting. But they have also raised new questions. For instance, how can SVAs expand voting opportunities during the pandemic? Where they exist, how can they be scaled up?

In response to these questions, International IDEA embarked on an effort to help electoral commissions across Europe, particularly in Eastern Europe. It conducted new research to map which countries allow
By developing knowledge products and organizing events, International IDEA supported electoral management bodies in Europe to recognize and manage complexities and risks in the electoral processes in response to the Covid-19 pandemic.

\section{Funding: Core}

what types of SVAs in Europe. It also brought together European electoral commissions to exchange their SVA experiences and learn from each other; and it advised individual European electoral commissions.

International IDEA's analysis of SVA legal frameworks in Europe helped electoral commissions to grasp the scope and breadth of these measures in a comparative context. Second, International IDEA partnered with the Association of European Election Officials to convene a series of online round table discussions on postal, early and mobile voting. These round tables brought together 22 European electoral commissions, from Portugal to Moldova and from the United Kingdom to Ukraine, to discuss the dos and don'ts of SVAs.

Lastly, International IDEA advised electoral stakeholders in various countries on the use of SVAs. In Armenia, the Institute advised electoral stakeholders on reforming their current system of out-of-country voting, which is another form of SVA.

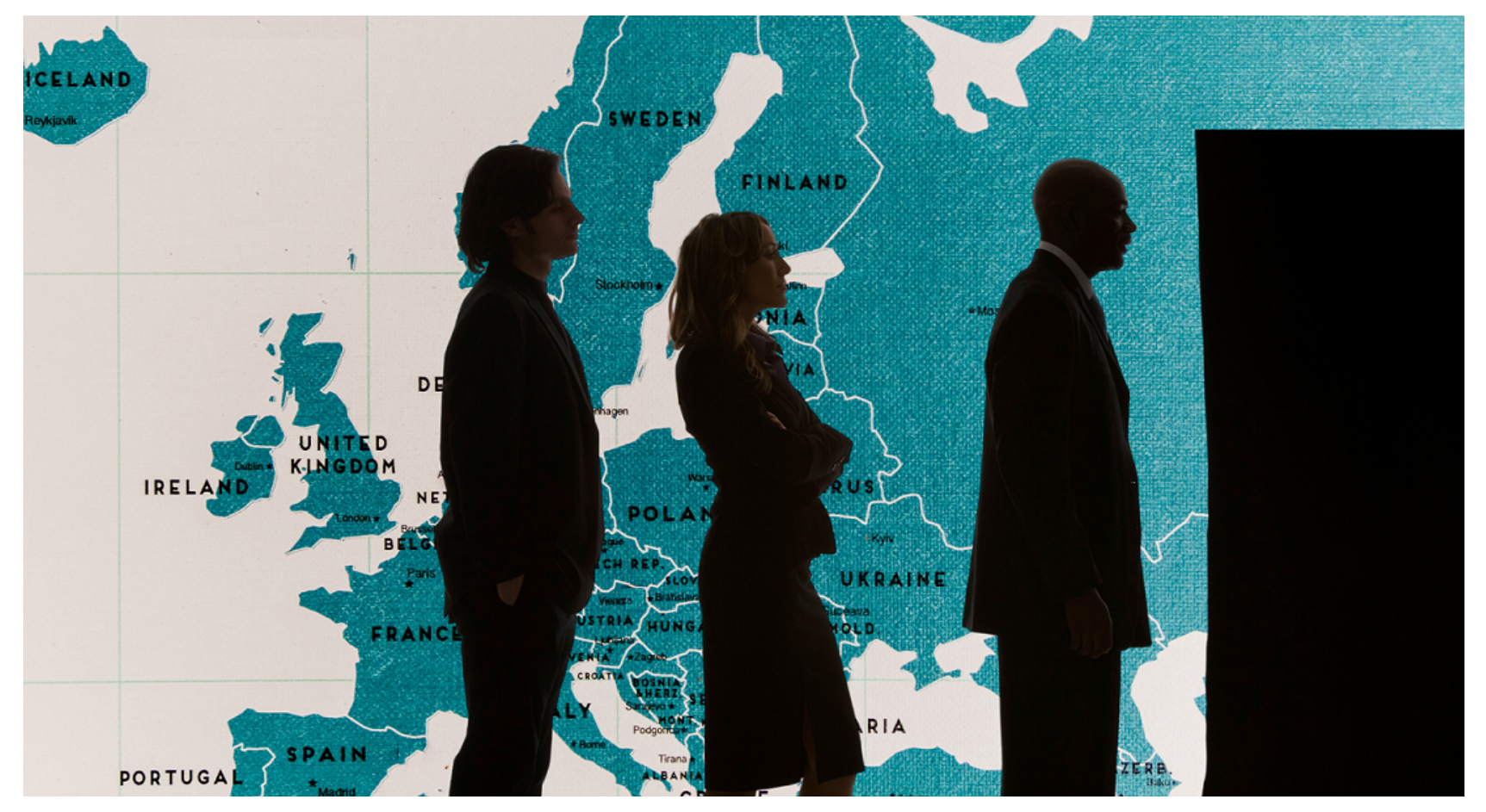

Special Voting Arrangements (SVAs) in Europe. Photo credit: International IDEA. 


\section{Enhancing the independence of electoral management bodies in the Arab region}

An analysis on the different models of EMBs and the criteria for their independence

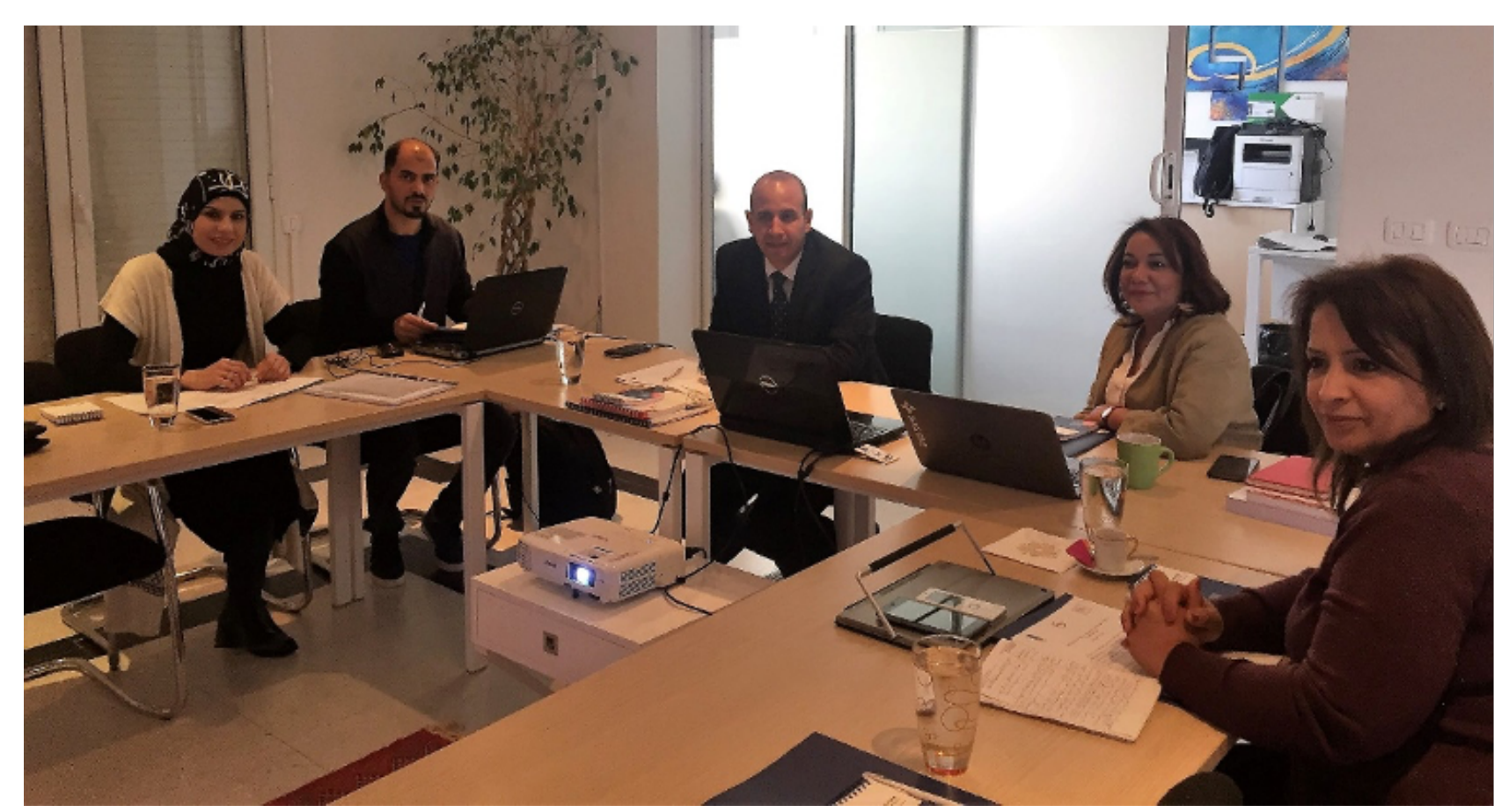

International IDEA held a meeting in its Tunis office between representatives from Arab EMBs and the UNDPArab States Regional Electoral Assistance Project to identify a working methodology.

The independence of EMBs, addressed in paragraph 20 of the General Comment to article 25 of the International Covenant on Civil and Political Rights, remains a thorny issue in the Arab region. The notion of independence applies to many aspects of EMBs and goes beyond mere structural independence from government.

To this end, the Arab EMBs Organization has requested the support of International IDEA and the UN Development Programme's Arab States Regional Electoral Assistance Project to develop a number of criteria to assess EMBs' independence.

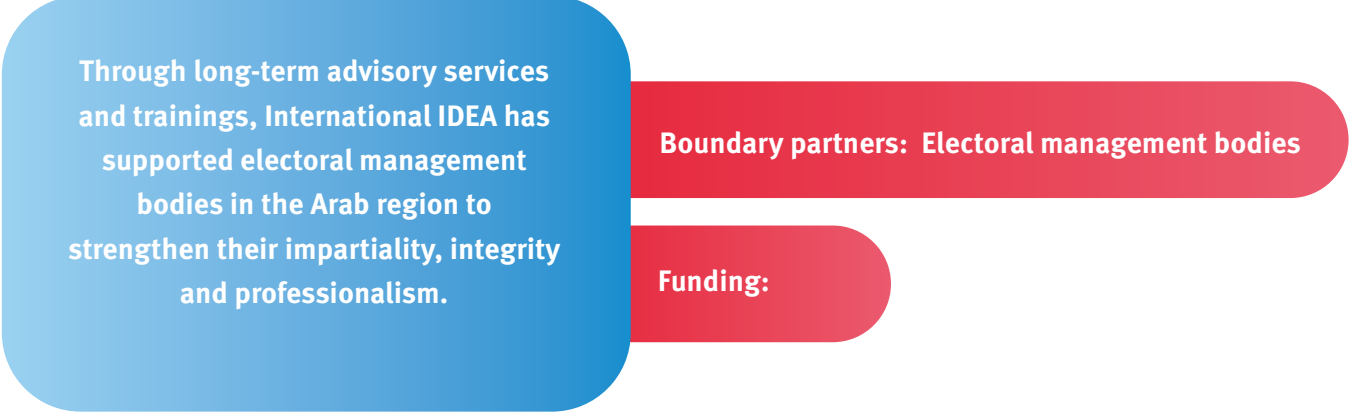

A group representing the organizations was formed and began to analyse the different models of EMBs in each country to identify common and specific aspects.

A long process of work and exchange meetings since 2018 resulted in an approved document outlining the criteria for EMBs' independence grouped into four essential elements- the legal framework, methods of selecting and appointing commissioners, EMBs' responsibilities, and control and accountability conditions. The document was reviewed by the previous president, current president and a member of the Executive Board of the Arab EMBs.

International IDEA's reference documents formed an essential basis for this work in addition to the information gathered from the participating EMBs—from Iraq, Jordan, Libya, Mauritania, Palestine and Tunisia. 


\section{Conducting safe democratic elections during the Covid-19 pandemic in Africa}

Information exchange and guidance for EMBs across the AWA region

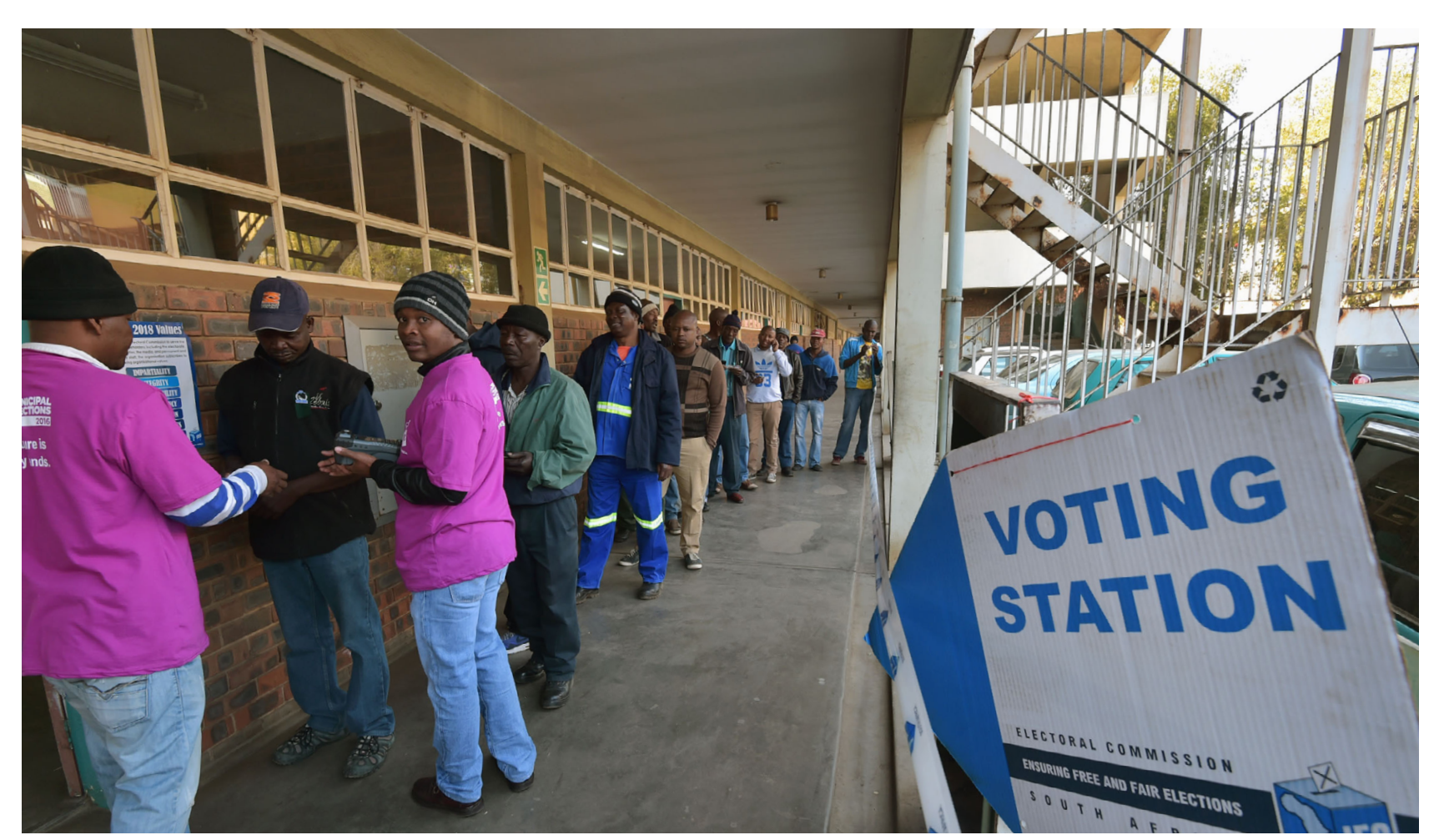

South Africans cast their vote in Diepsloot during 2016 Local Government Elections. Photo credit: GCIS / Flickr

The Electoral Processes (EP) and Africa and West Asia (AWA) teams sought to provide platforms for information exchange and guidance for election management bodies (EMBs) across the AWA region to alleviate uncertainty about the conduct of safe and democratic elections during the pandemic.

International IDEA collaborated with two regional networks of EMBs to organize webinars in the Arab and southern Africa regions. These opened channels of communication and peer learning that culminated in peer assistance among EMBs that conducted elections in 2020.

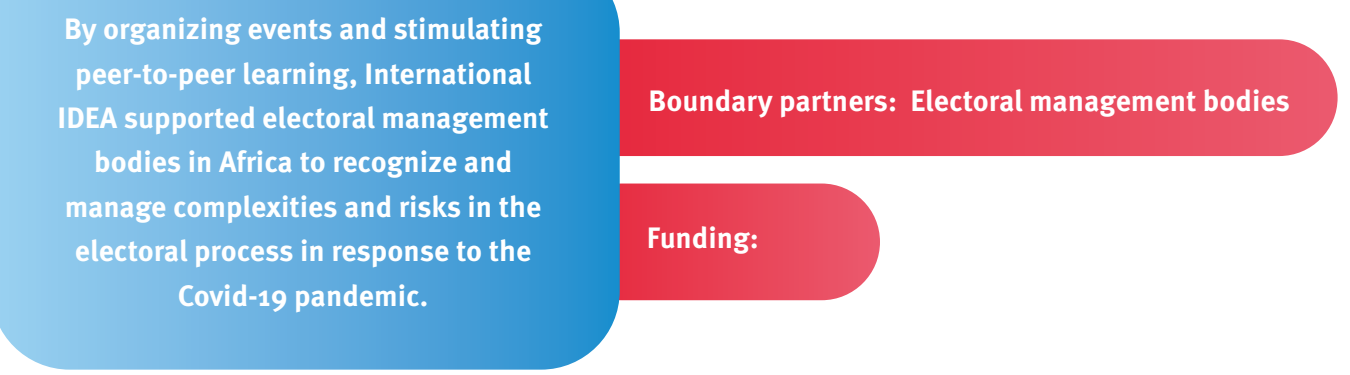

The AWA team also contributed to knowledge production through support and input to the global EP team on International IDEA's Global Overview of Covid-19: Impact on Elections.

Moreover, the team provided technical assistance to the Democracy and Electoral Assistance Unit of the African Union Commission to develop the African Union Guidelines for Elections during Covid-19 and Other Public Health Emergencies.

The Global Overview and Africa-specific media articles and engagements were key reference documents for EMBs navigating the difficult terrain of conducting elections.

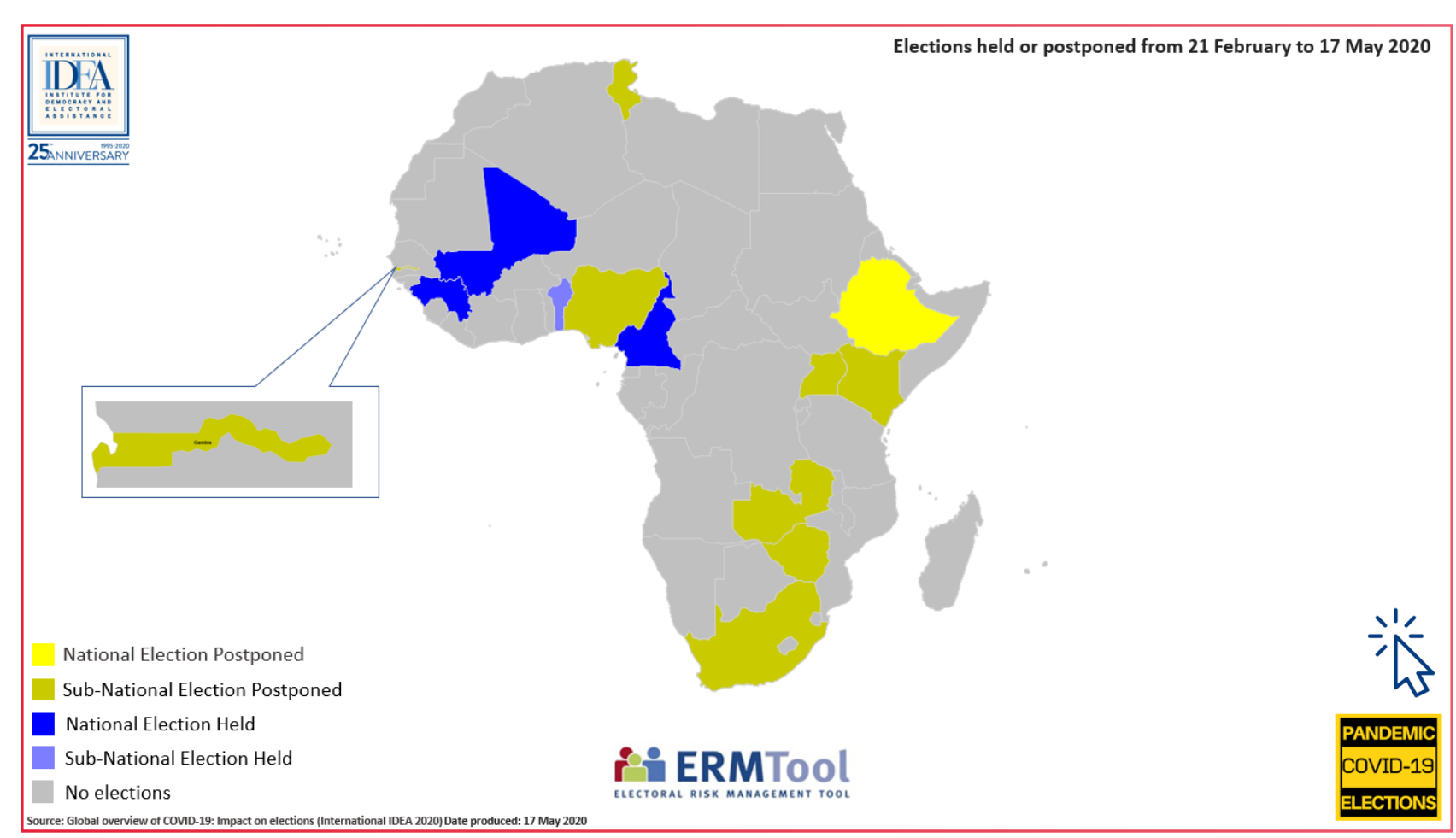




\section{Promoting best practices among electoral management bodies in Southern Africa}

Post-election assessments and developing the electoral reform agenda
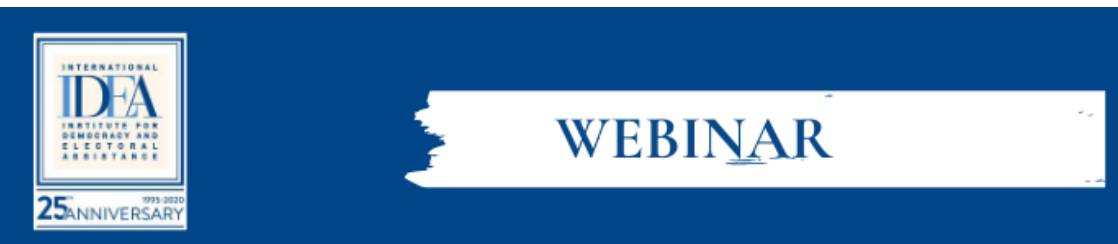

LESSONS FROM

MALAWI'S PRESIDENTIAL ELECTIONS OF 23 JUNE 2020
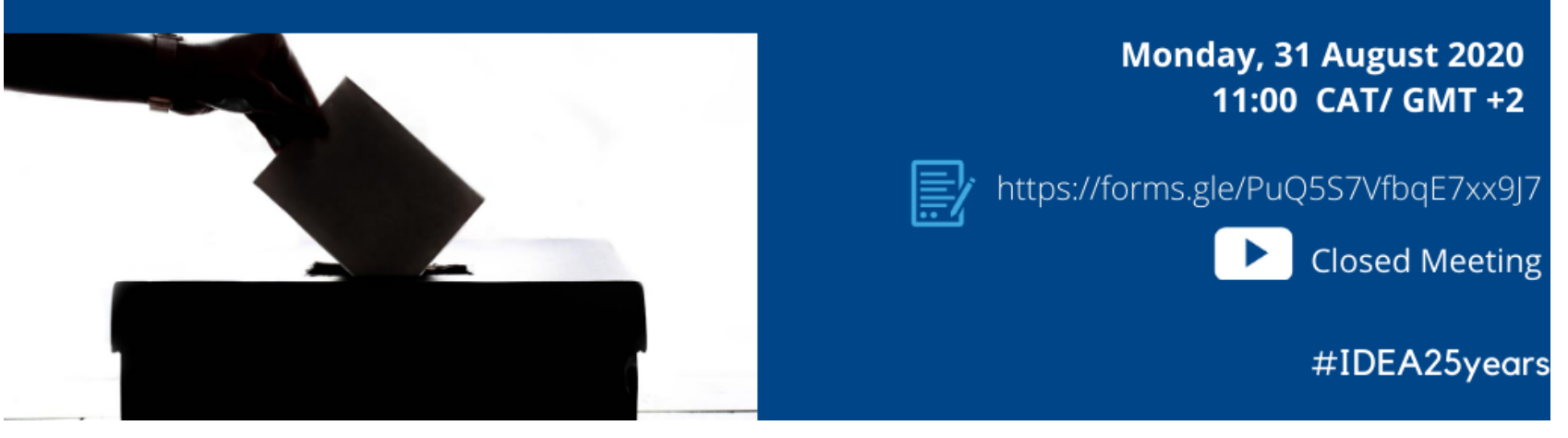

The electoral cycle approach recognizes the importance of post-election assessments and evaluations for lesson learning and developing the electoral reform agenda. Eight elections were held in southern Africa in 2019, which led to landmark events in the region. The Malawi High Court overturned the results of the 2019 presidential elections in January 2020, and landmark court judgements in South Africa significantly amended the country's electoral system after 25 years of multiparty democracy.

As part of its efforts to promote lesson learning at the national and subregional levels, International IDEA's Electoral Processes and Africa and West Asia teams, in collaboration with the Electoral Commissions Forum of Southern African Development Community Countries (ECF-SADC), organized a webinar to review the 2019-2020 elections in Malawi and assess developing trends in electoral justice in the region. The webinar provided a platform to draw lessons on the judiciary's role in strengthening democracy in the region and the importance of electoral systems in promoting inclusive electoral processes.

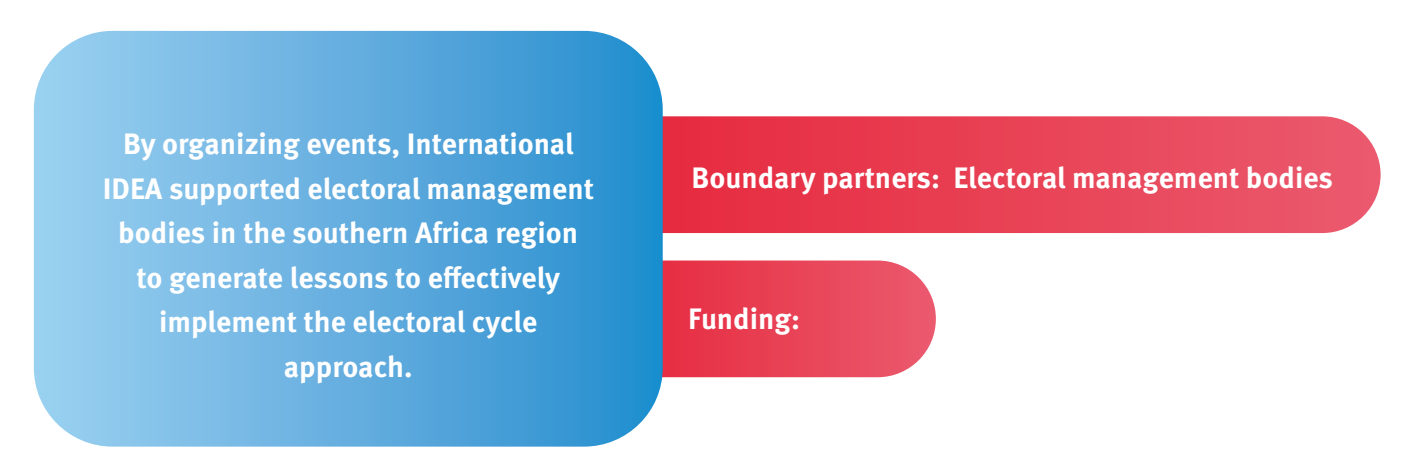

The report on the webinar has been disseminated to ECF SADC member commissions and will serve as the basis for further collaboration on the themes of electoral justice and EMB independence in the region.

At the national level, the Africa and West Asia team provided technical assistance to Botswana's Independent Electoral Commission (IEC) to conduct its national stakeholder post-election evaluation workshop. The workshop provided a platform for feedback from the country's national stakeholders on the conduct of the 2019 elections. Stakeholders identified the emerging risks associated with using social media in election campaigns as well as opportunities to strengthen the IEC's institutional independence and credibility. The workshop made recommendations to guide the IEC in developing a reform agenda over the next electoral cycle. International IDEA will continue to provide support to the electoral process in Botswana, which is an International IDEA Member State.

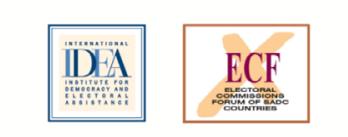

Lessons from Malaw's Fresh Presicticial Letions
of 23 lune 2020

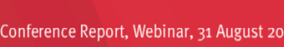

"The year 2020 saw the outbreak of the Covid-19 pandemic, which greatly impacted the mode of operations for many organizations. The ECF-SADC was not spared the impact of the pandemic, which necessitated the suspension of staff travels and physical or on-sight meetings. With the support of International IDEA, the ECF-SADC was able to continue with its mandate of promoting peer learning and experience sharing among EMBs in the SADC region through the webinars and the virtual Annual General Conference of the Forum.

International IDEA's culture of documentation and publication has strengthened the ECF-SADC mandate of promoting knowledge base and expertise on electoral matters. All proceedings of activities were professionally captured, shared for input by other relevant stakeholders and documented for publication professionally captured, shared for input by other relevant stakeholders and documented for publication
on various online platforms. The availability of meeting recordings provided efficient backup for capturing proceedings."

- Hilda Modisane, Executive Secretary of ECF-SADC 


\section{Guiding Indonesian stakeholders to navigate the impact of Covid-19 on elections}

Uptake in policymakers' utilization of data on holding elections during the pandemic

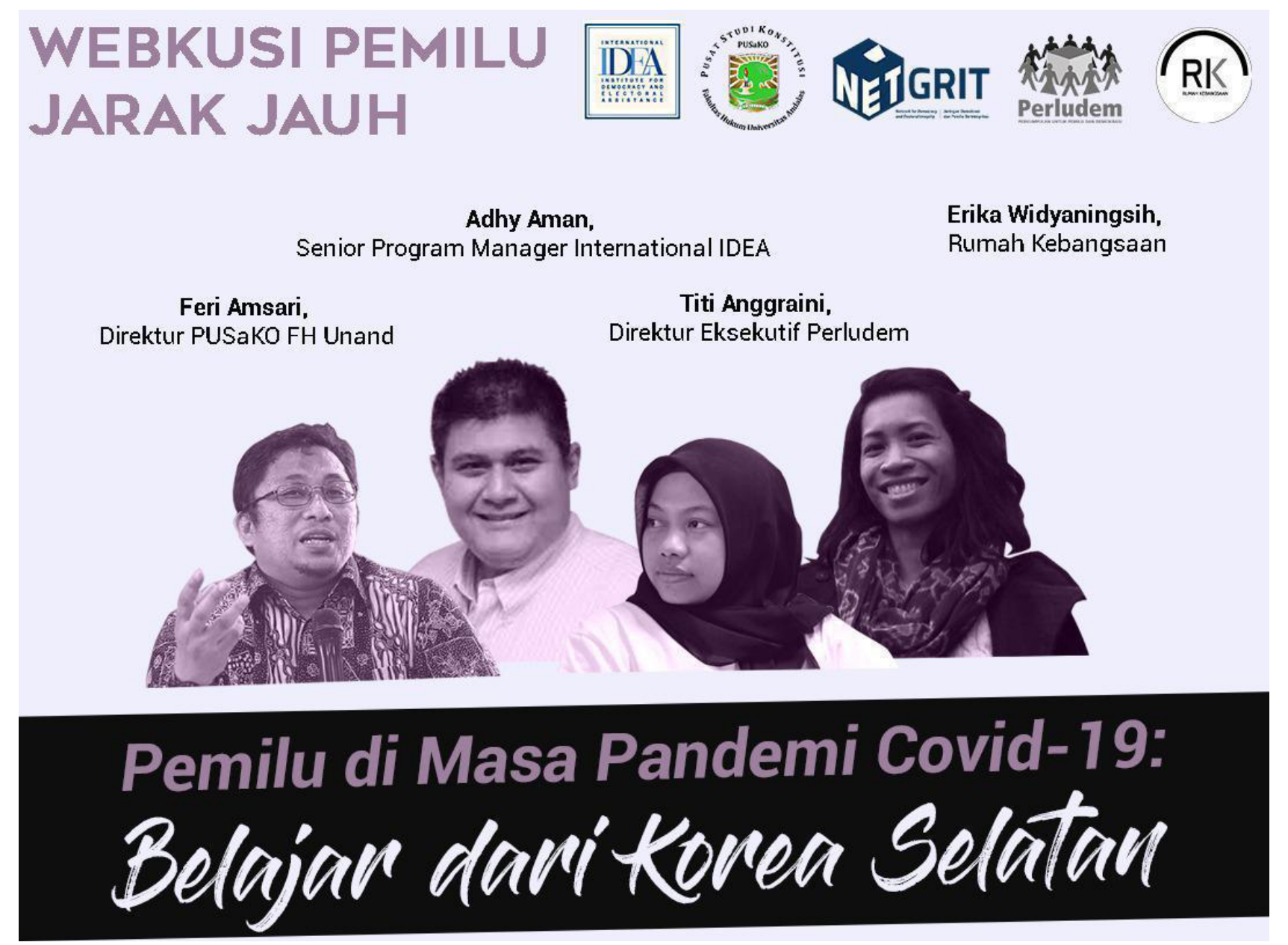

Beginning in March 2020, International IDEA developed and regularly released data and analyses on the impact of Covid-19 on elections. Indonesia, which had 'head of region' elections in all provinces except Aceh that involved more than 100 million voters scheduled for September, was very interested in receiving a substantial amount of information on holding elections during the pandemic.

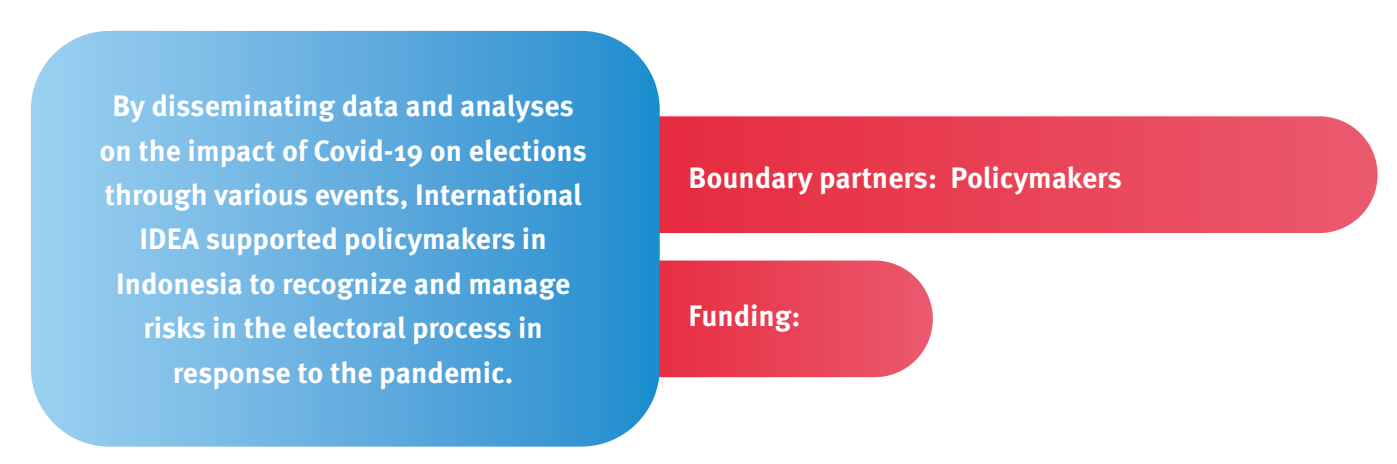

The presence of International IDEA experts in many webinars and, more importantly, the availability of materials translated into Bahasa Indonesia — thanks to a long-term close partnership with the Association for Elections and Democracy (Perludem) — contributed to the uptake in policymakers' utilization of data and analyses.

Through Akmal Malik, Director General for Regional Autonomy, Tito Karnavian, the Minister of Home Affairs, expressed his appreciation and gratitude for the data and analyses provided while the decision to suspend the elections was being considered. Indonesia's Home Affairs Ministry was at the forefront of ensuring the elections could take place in 2020 with adequate health and safety protocols.

"Together with other activists and many electoral stakeholders in Indonesia, such as the Election Commission, the government and mass media, I have taken advantage of the many Covid-19 and elections materials produced by International IDEA as well as taking part in related activities. We are thankful for International IDEA's self-initiatives and we hope such useful endeavour shall continue."

- Hadar Nafis Gumay, a former election commissioner and founder of the Network for Electoral Integrity
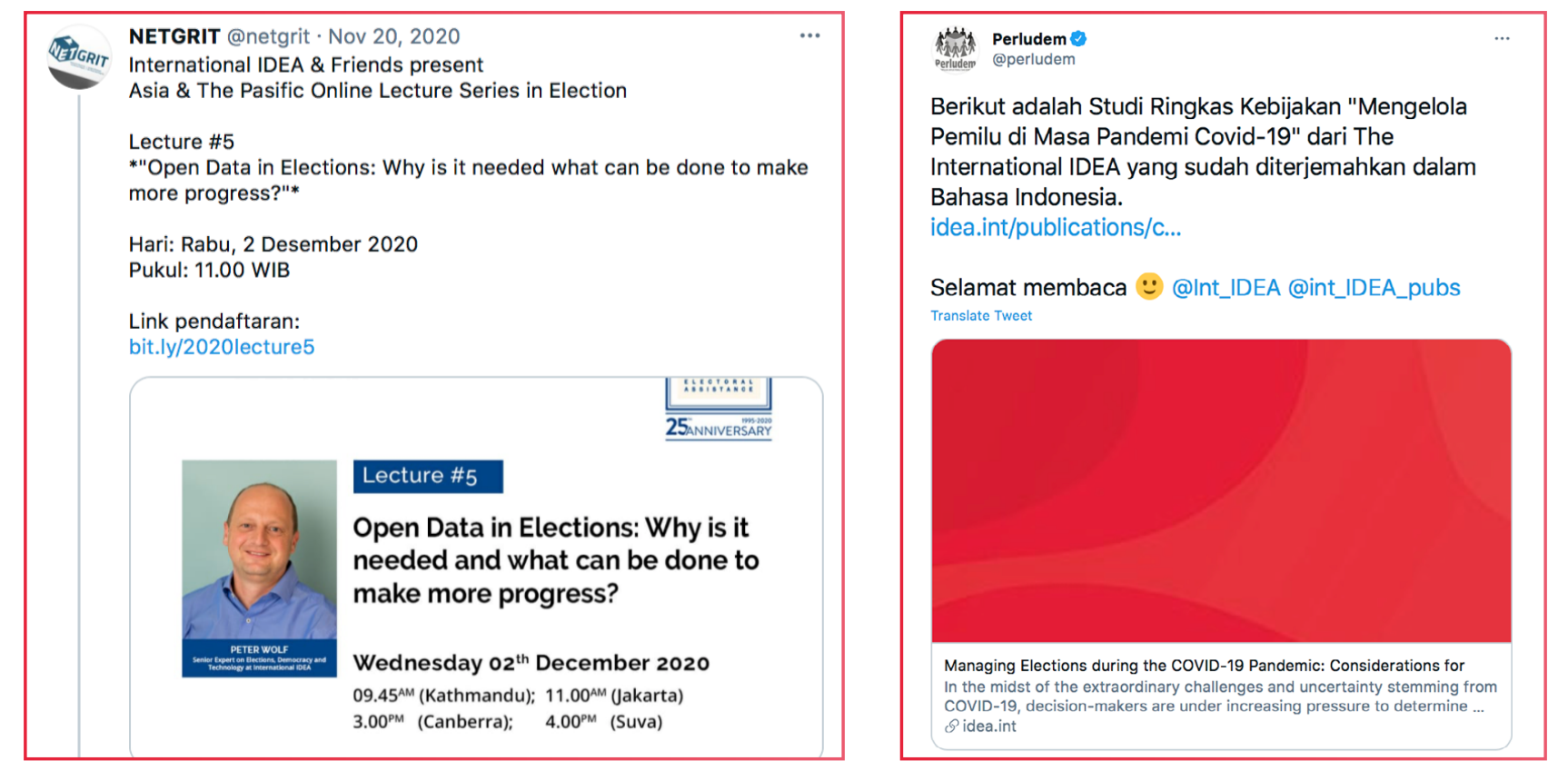


\section{Promoting pioneer management of Covid-19 era elections by the Republic of Korea}

A shift from the initial trend to postpone elections that characterized the early months of the pandemic

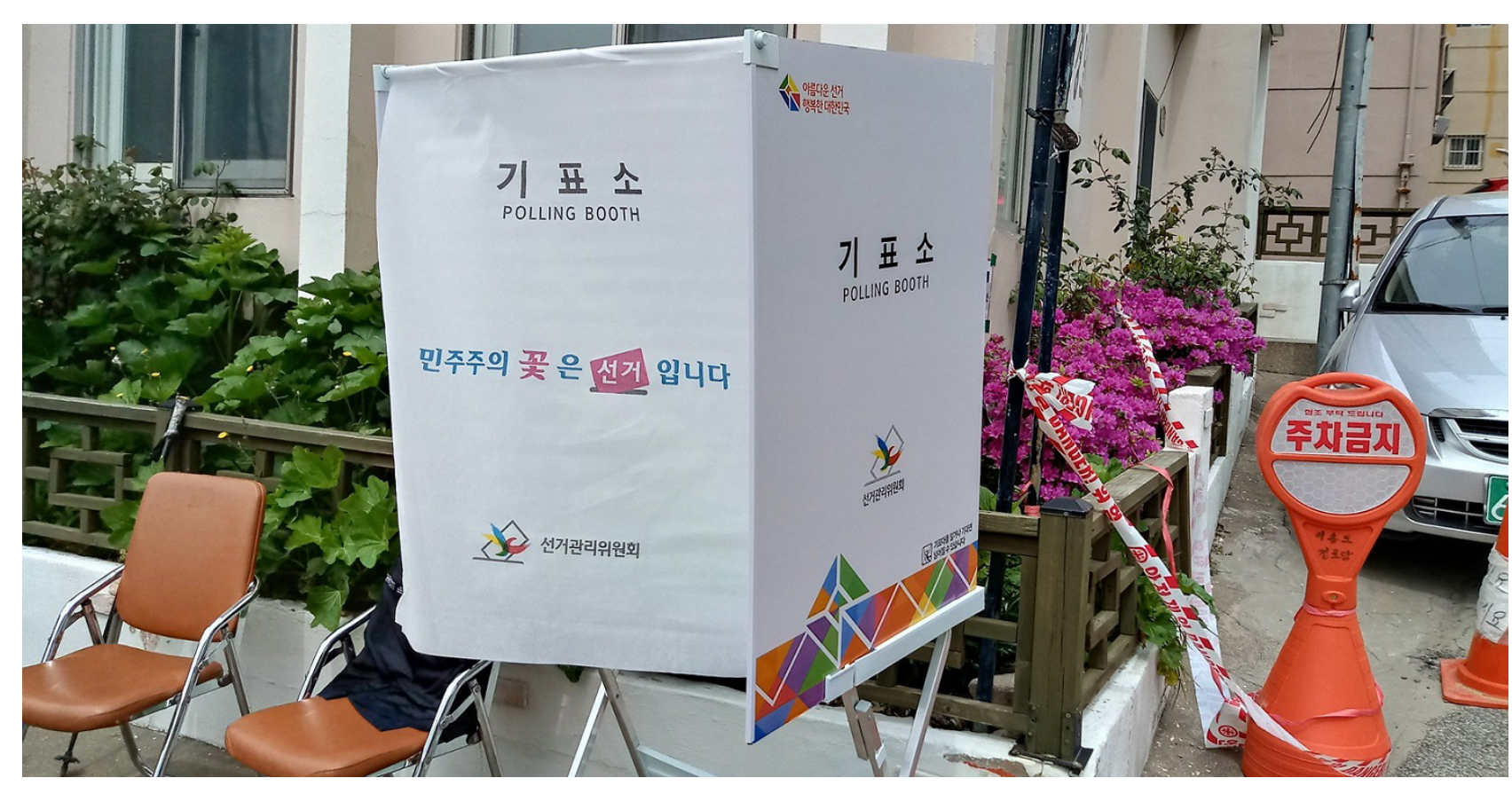

Photo credit: Jens-Olaf Walter / Flick

Capturing and sharing comparative knowledge at a critical juncture, when there is a gap, acts as a conduit for peer support among electoral management bodies around the world. Since the early stages of the outbreak, Covid-19 placed unprecedented pressure on countries to decide whether to hold or postpone their scheduled elections. Confronted with the prospect of potentially spreading the virus, numerous countries opted to defer the vote; the Republic of Korea was one of the first to decide to hold elections as scheduled-for the National Assembly, in April 2020.

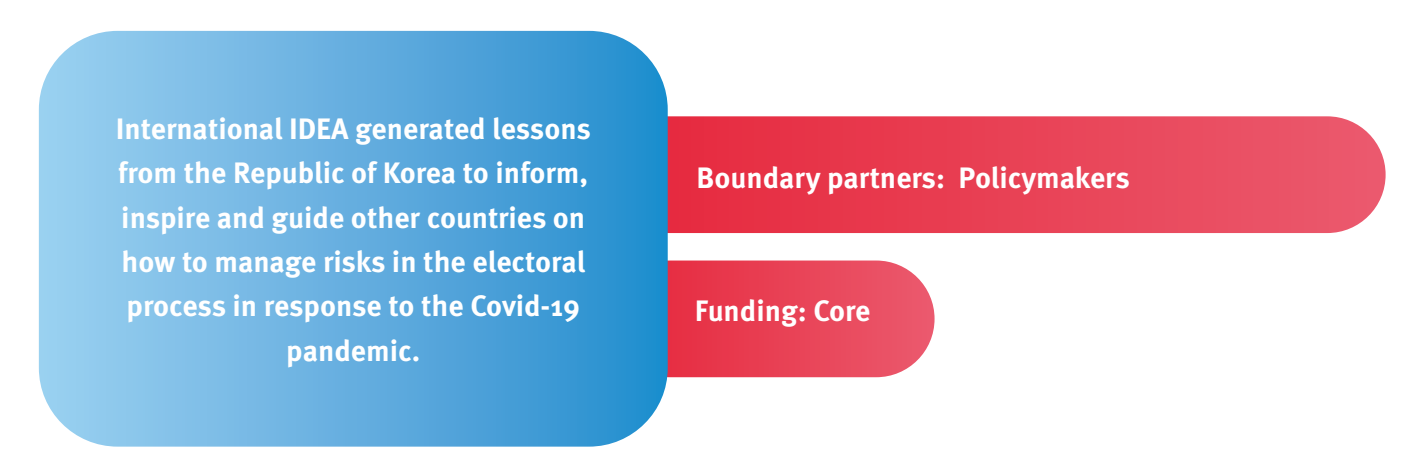

International IDEA's Technical Paper, 'Managing Elections under the Covid-19 Pandemic: the Republic of Korea's Crucial Test', closely analysed these elections and extracted key lessons to be learned. Sharing this knowledge globally through numerous events has helped inform, inspire and guide other countries that are holding elections during the pandemic.

This knowledge has contributed to a shift in the initial trend to postpone elections that characterized the early months of the pandemic. The new global trend is to hold elections, using the risk mitigation measures pioneered by the Republic of Korea.

International IDEA has supported a wide range of its boundary partners in their efforts to understand the conditions, measures, equipment and behaviours needed to ensure a safe, technically sound and participatory election during a pandemic.

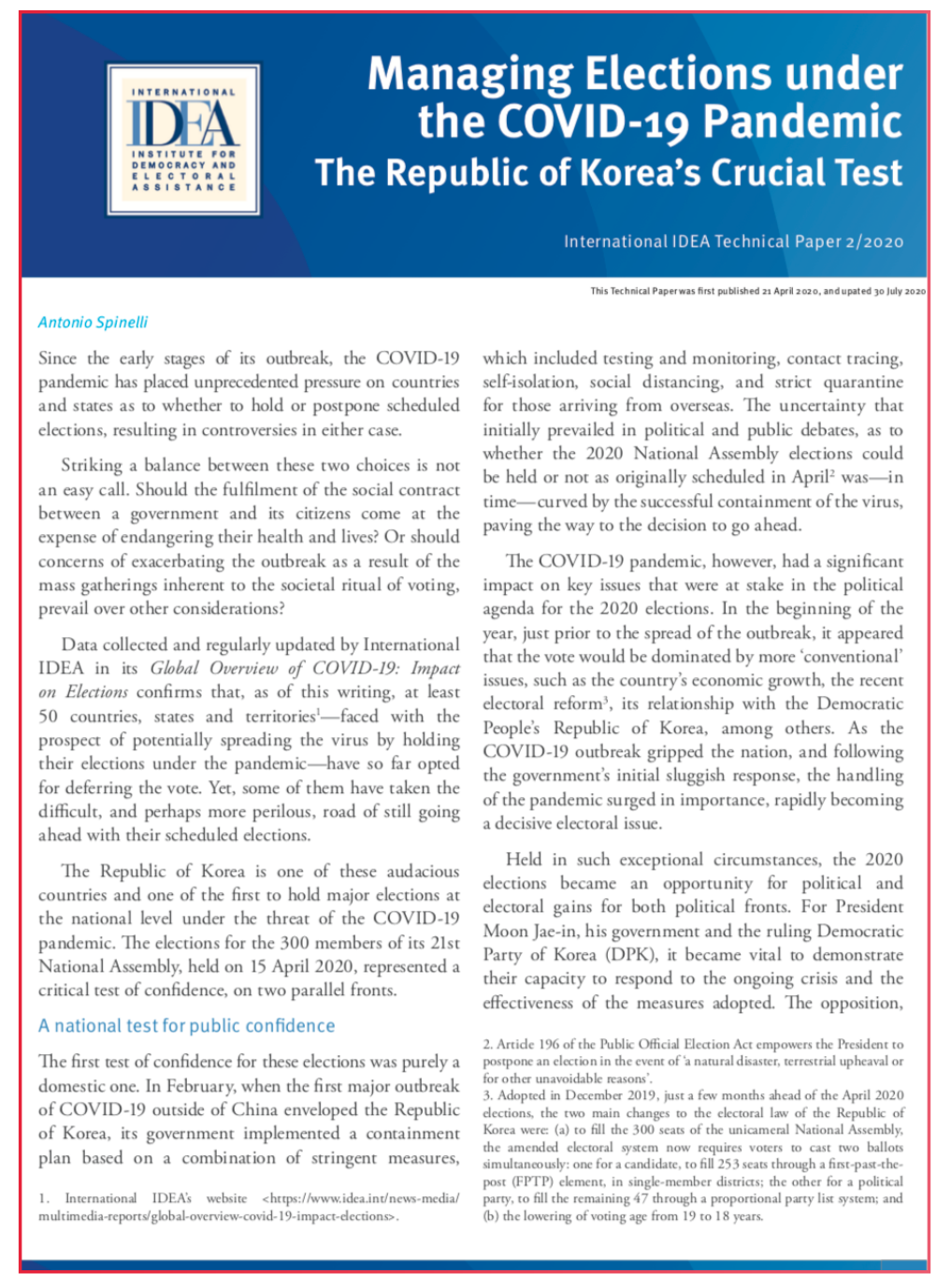




\section{Myanmar 2020 elections: helping a democratic transition}

The European Union (EU)-funded programme 'Support to Electoral Processes and Democracy - STEP Democracy' worked with Myanmar's key election stakeholders-the Union Election Commission (UEC), political parties and civil society-to prepare inclusive 2020 elections. While progress has been made in strengthening the technical process of elections, challenges related to establishing and implementing an inclusive legislative and policy framework for elections must be addressed in order to strengthen Myanmar's democratic process, the enfranchisement of disadvantaged groups and its citizens' idea of democracy.

Addressing EU election observation recommendations

The UEC has worked to address the EU's election observation recommendations from 2015 with support from International IDEA's embedded office within the commission. For instance, the UEC has revised election by-laws to allow military voting outside of barracks, enhanced transparency, increased outreach to political parties, media and civil society, and allowed free access to election observers.

NOTE: On 1 February 2021, Tatmadaw—Myanmar's armed forces— seized power by detaining President Win Myint, State Counsellor Daw Aung San Suu Kyi, and other high-level government officials and declared a one-year state of emergency. The Military is citing errors in voters list as reason for rejecting the results of the November 2020 elections and staging the coup. The military has appointed a new Union Election Commission (UEC) to oversee a 'new' election. The Chairperson, Deputy Chairperson, and the Spokesperson of the former UEC remain in detention in undisclosed locations. National and international observers had issued reports indicating that the elections were conducted in accordance with the relevant international standards and principles. As of 4 March 2021, the military and police have killed 54 peaceful protestors demanding restoration of democracy.

Engaging in dialogue with civil society

Despite increased public scrutiny, the UEC engaged with civil society and international election observation organizations in a STEP workshop facilitated by International IDEA and Democracy Reporting International (DRI) to review accreditation procedures. The UEC revised these procedures in July 2020, taking the civil society proposals into account. Civil society organizations observed the 2020 elections and monitored social media using methodologies developed in STEP strategic planning workshops with the DRI's support. The UEC increased its outreach to political parties via its subcommissions through countrywide STEP dialogues facilitated by the Danish Institute for Parties and Democracy (DIPD), which focused on topics such as electoral rules and regulations.

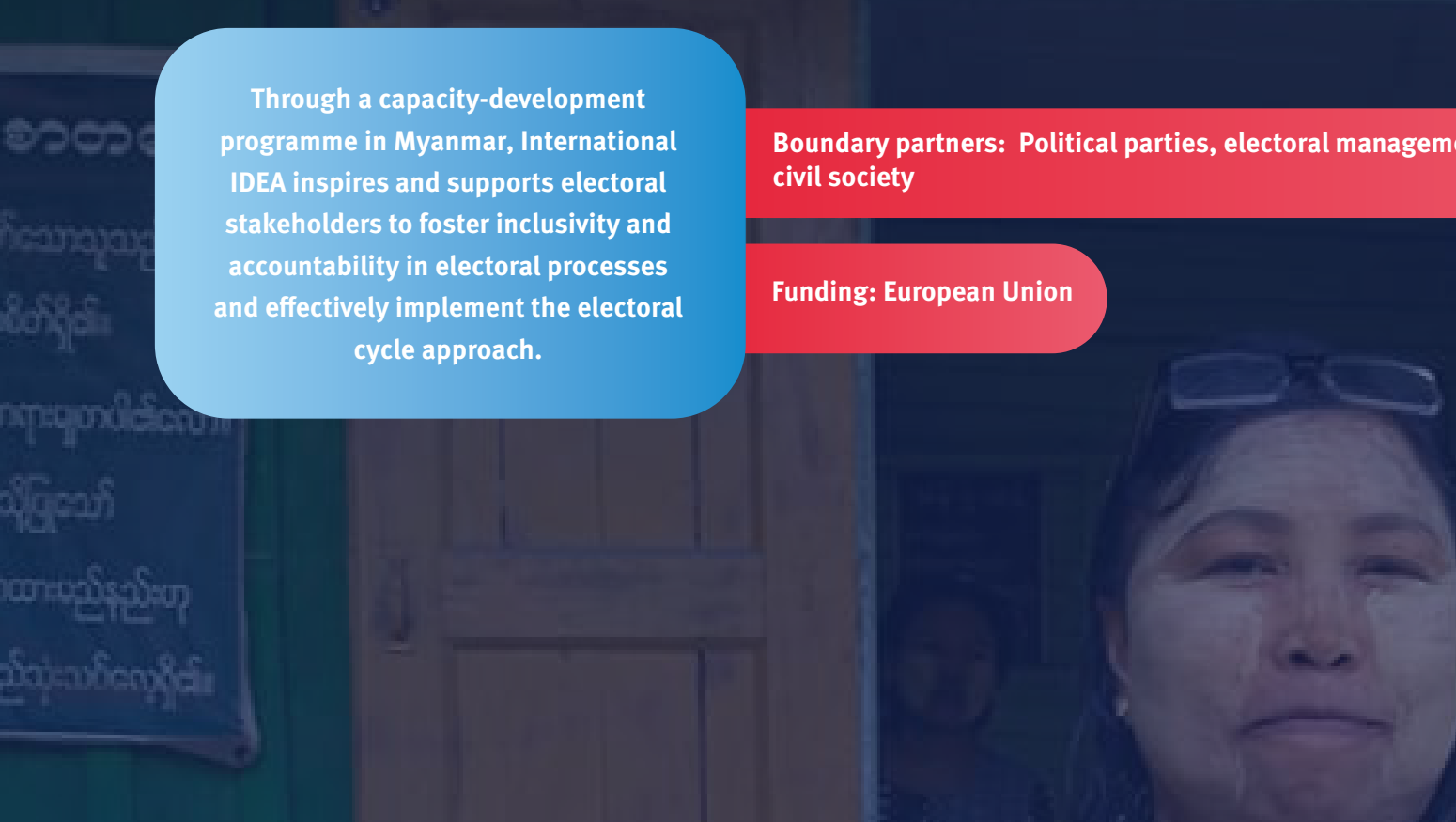

Strengthening women and youth participation in political parties

Political parties in Myanmar have worked to strengthen their internal democracy and give voice to the concerns of women and youth by learning how to establish political party structures such as women caucuses and youth wings at the region and state levels in STEP workshops and trainings conducted by the DIPD and the Netherlands Institute for Multilateral Democracy (NIMD)/DEMO Finland. In preparation for the 2020 elections, more than 100 women politicians worked in DIPD-and NIMD/ DEMO-facilitated STEP workshops and trainings on their campaign management skills, including public speaking and empowerment, and increased their knowledge of Myanmar's political system and the Code of Conduct for Political Parties. In the 2020 elections there was a noteworthy increase in the number of women candidates elected to legislatures from 13 per cent in 2015 to 18 per cent in 2020 . Of 1,117 candidates in the 2020 elections, 78 young candidates ( 7 per cent) were elected. Further progress is needed to encourage political parties to empower women and young people.

More than 170 political party representatives worked on conflict resolution skills in STEP trainings conducted by NIMD/DEMO. At the subnational level, the STEP Women's Academy organized by the DRI involved more than 1,500 participants and provided women municipal committee members with a platform to engage with township residents to outline and discuss municipal development plans and challenges, and to respond to citizens' concerns.

\section{Voter and civic education}

The public benefited from a series of STEP voter and civic education activities focused on new voters, women and youth in remote areas organized by the Scholar Institute,'Panna Institute and Badeidha Moe. Before Covid-19 restrictions took effect, civic education sessions for more than 1,500 adults and 200 students/teachers in Kachin, Chin, Magway and Ayeyarwady were conducted.

Under the leadership of the UEC, the TV broadcast series 'MyVote' supported by STEP and developed in cooperation with International IDEA provided the public with different perspectives of challenges faced by voters. 


\section{Empowered CSOs contribute to electoral risk management}

International IDEA's lessons learned in 2020 offer practical evidence and inspiration

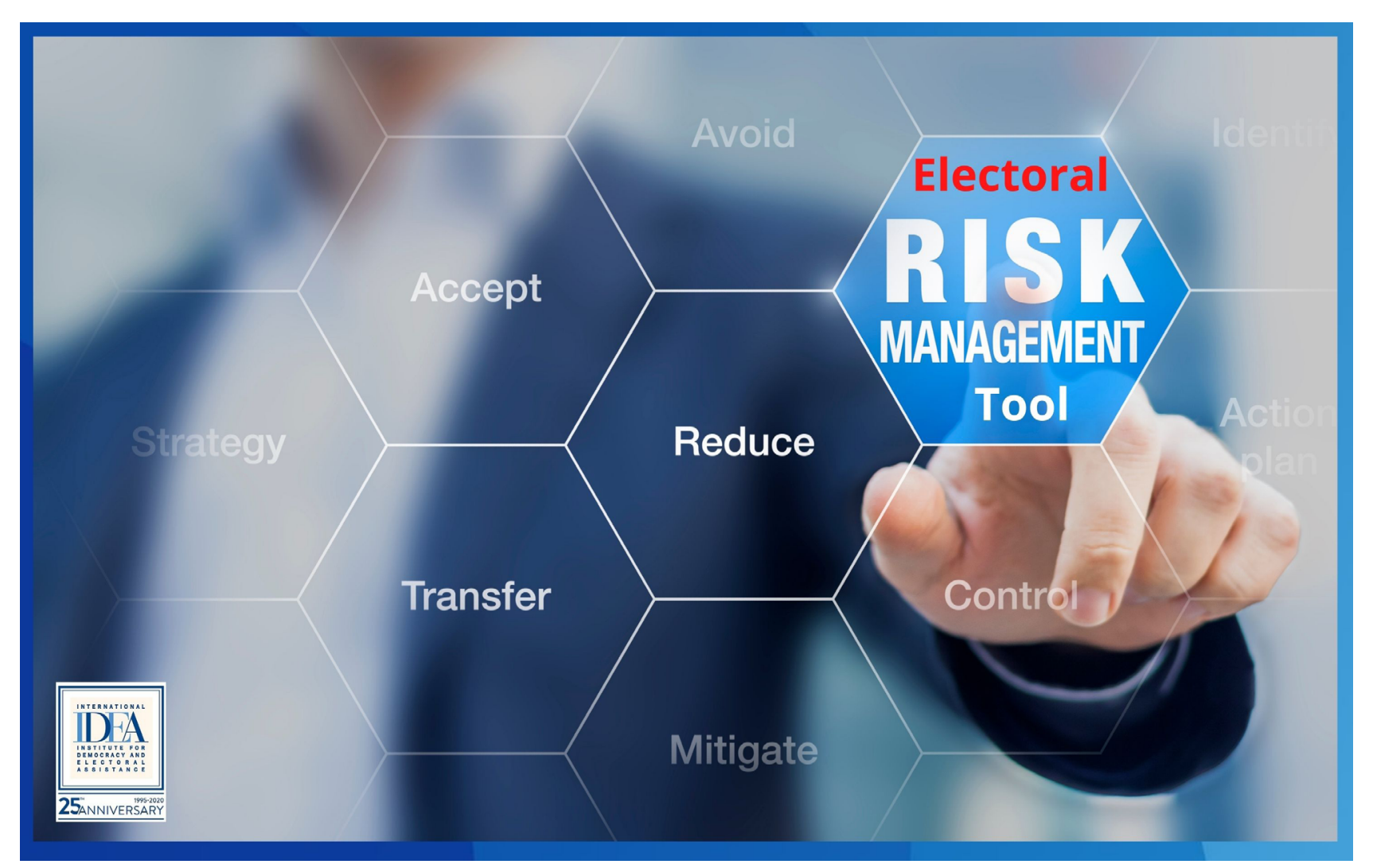

Electoral management bodies (EMBs) are increasingly expected to engage in the systemic management of electoral risks. Yet civil society organizations' (CSO) role in broader efforts to prevent and mitigate electoral risks remains vaguely understood. International IDEA's experiences and lessons learned in 2020 offer practical evidence and inspiration.

Since the global launch of International IDEA's Electoral Risk Management Tool (ERMTool) in 2013, the Institute has supported over $20 \mathrm{EMBs}$ worldwide in implementing the methodology. In 2020, the focus of the Electoral Conflict and Risk Management project was strengthening CSOs to contribute to national efforts to prevent and mitigate electoral risks.

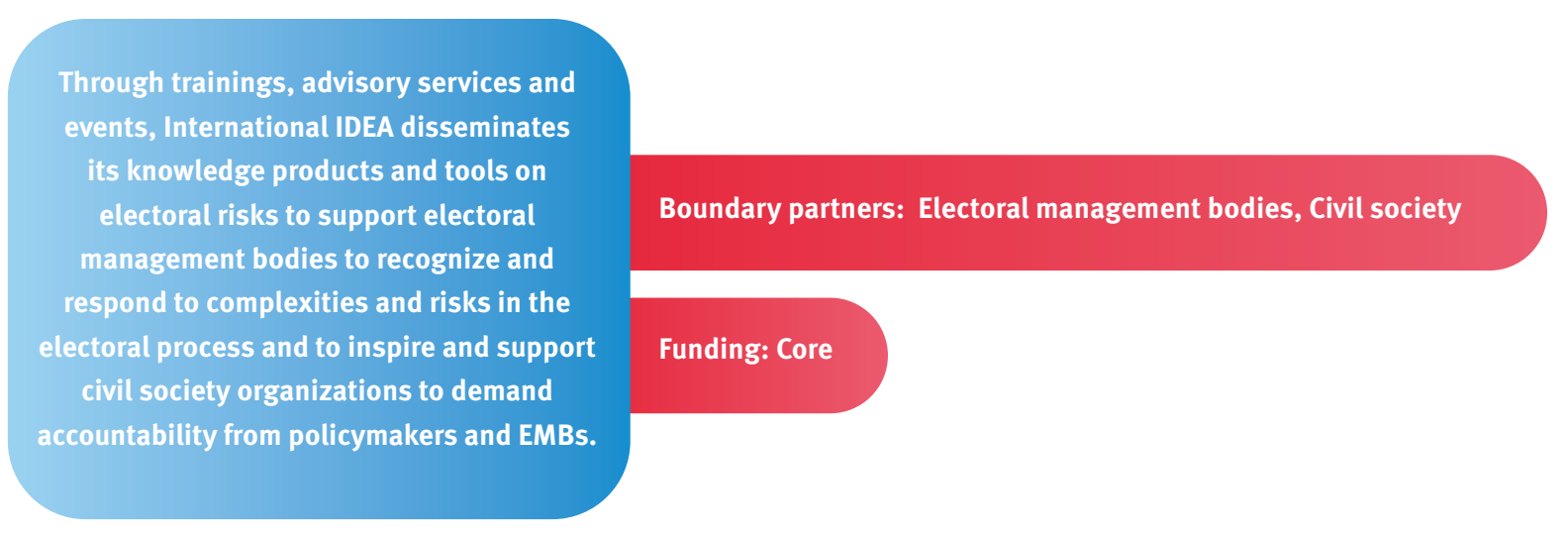

In North Macedonia, the Centre for Good Governance and Integrity-HUB approached International IDEA for knowledge resources, training and advisory support. The HUB established an exchange of information with political parties and the State Election Commission (SEC) to identify areas in which joint activities should take place to prevent electoral anomalies. The HUB conducted surveys before and after election day, analysed data using ERMTool's software and continuously shared reports, in the form of risk alerts and recommendations, with the SEC. At the end of the project, the HUB transferred the risk and action register to the SEC to use in future elections.

In Kyrgyzstan, the Center for Strategic Analysis, Dialogue and Development in Central Asia used the ERMTool to analyse risks related to the rights of voters and candidates, freedom and access to the media during the pre-election period. Election day monitoring also took Covid-19 risks into account.

The Electoral Processes team also worked closely with International IDEA's Africa and West Asia Programme to introduce the ERMTool to a group of Ugandan CSOs, which increased their interest in engaging on the topic. Furthermore, the two teams customized ERMTool-related guides on internal and external risk factors to electoral processes in the G5 Sahel Region.

In 2020, a record number of 92 organizations applied for the ERMTool's software download key. Determined to strengthen its support to democracy practitioners who face ever-increasing risks in organizing elections, International IDEA provided open access to ERMTool source codes. With this initiative, the Institute encourages users to customize the instrument to their needs and to share any improvements with their peers.

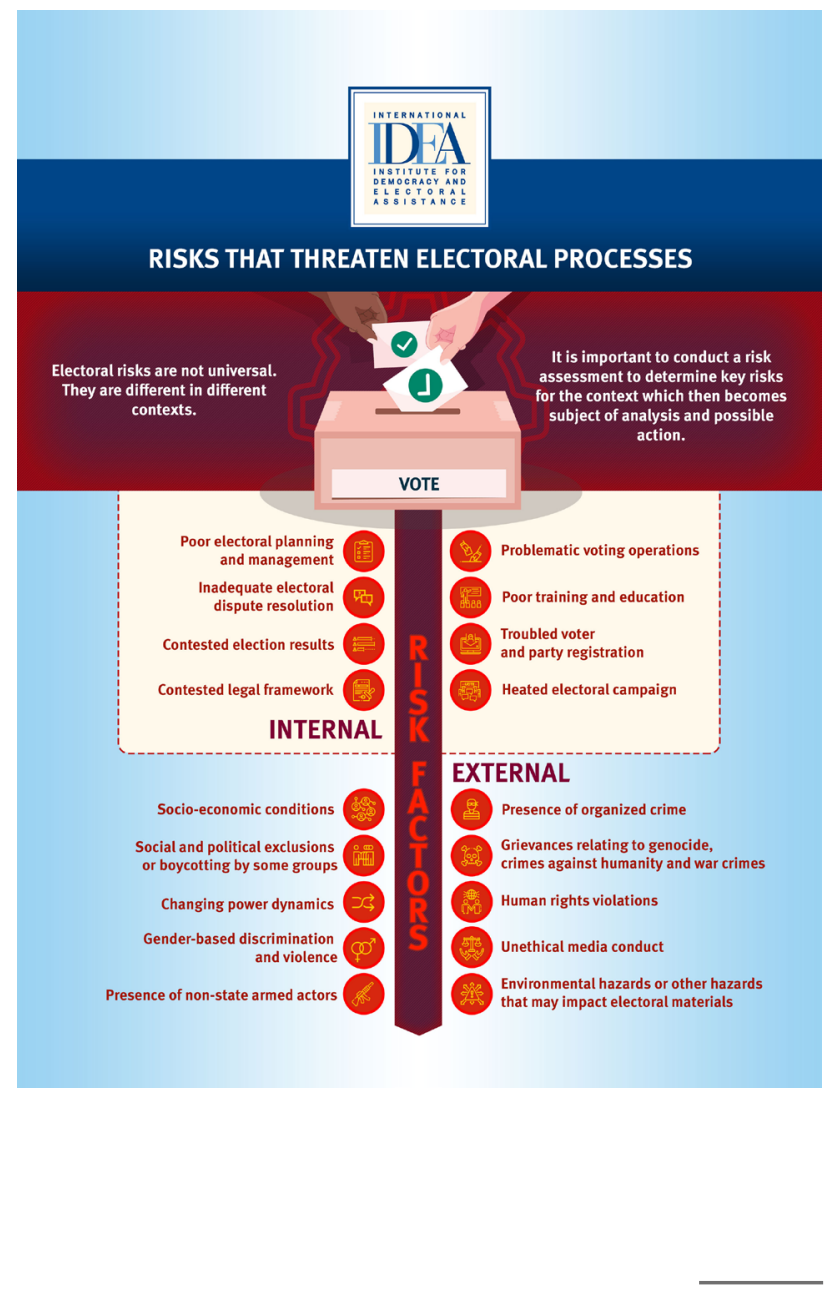




\section{Strengthening electoral cooperation in Latin America}

An exchange of experiences on the pandemic's impact on electoral processes

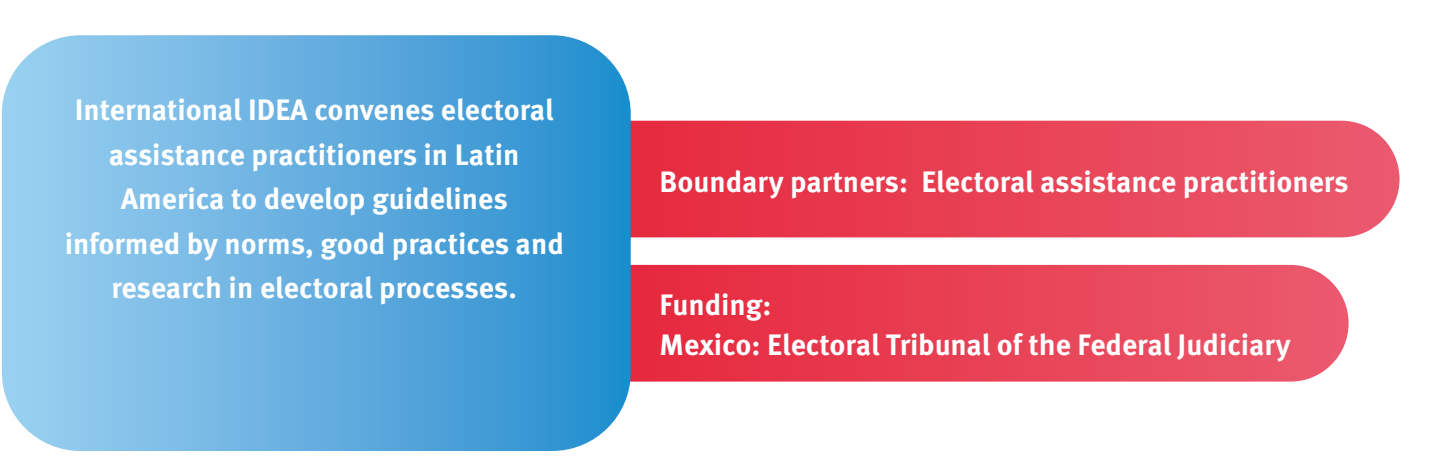

Facing the challenges that the pandemic presented to Latin American governments, International IDEA, along with the Global Electoral Justice Network, supported government cooperation to strengthen regional capacity by gathering electoral experts and electoral authorities to discuss issues such as electoral justice and democratic best practices.

Since May 2020, the group have held 16 meetings to exchange experiences on the pandemic's impact on electoral processes. Judges and electoral officers from Argentina, Bolivia, Chile, Colombia, Costa Rica, the Dominican Republic, Ecuador, Guatemala, Honduras, Mexico, Panama, Paraguay and Peru have discussed (a) electoral justice, (b) technology applied to electoral processes, (c) voting modalities and mechanisms, (d) gender equality and (e) sanitary protocols. The main output of the meetings was guidelines that systematized the expert contributions. The high-level group will continue in 2021.

The cooperation among the electoral authorities improved the response on the organization of electoral processes in the region by implementing sanitation measures for each part of the electoral process, guaranteeing the execution of their voting rights without risking the national health situation.

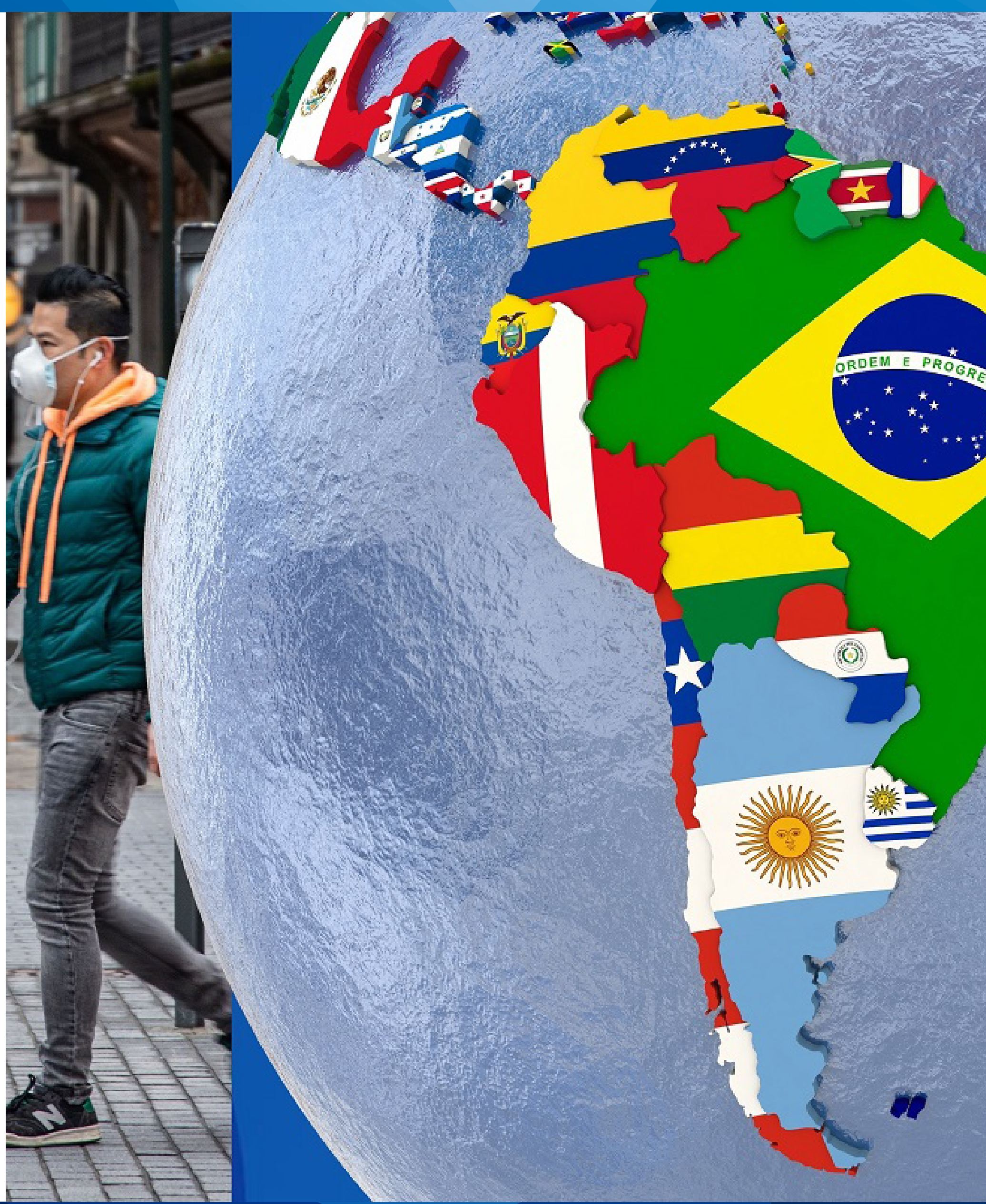




\section{Institutionalizing election observation within the Melanesian Spearhead Group}

Supporting the Vanuatu elections observation mission in March 2020

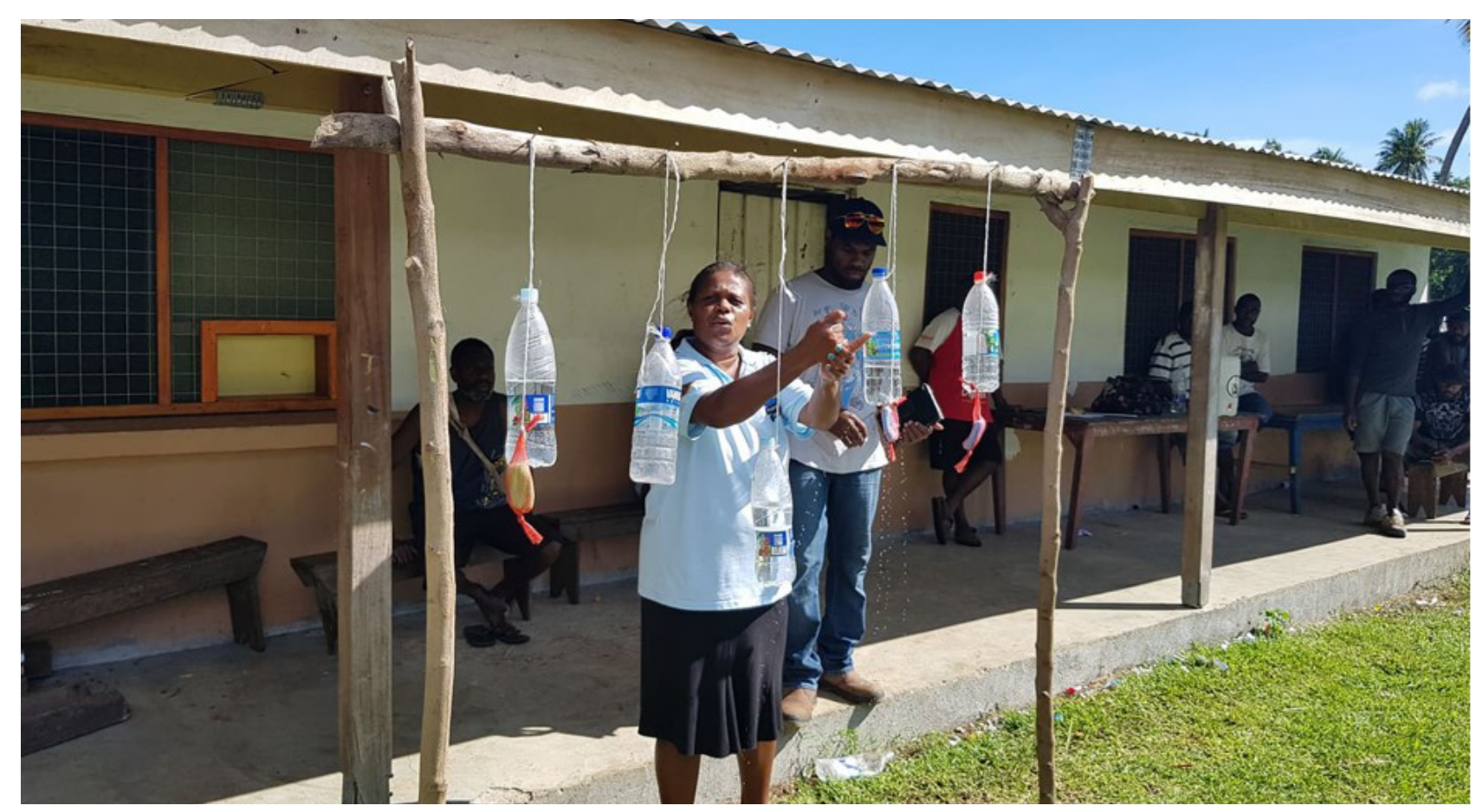

On the Election Day (19 March 2020) voters were made to wash their hands before casting ballots in a polling station on Malekula Island as a precaution against Covid-19. Health workers are seen working with election officials in explaining how the hand washing should be done. Photo credit: MSGS

Election observation experts have been working with Melanesian Spearhead Group Secretariat (MSGS) staff to institutionalize their election observation methodology and procedures as part of a Memorandum of Understanding between International IDEA and the MSGS.

Following a training on international observation missions in late 2019, International IDEA experts provided advice directly to the Melanesian Spearhead Group's observation mission to the Vanuatu elections in March 2020.

This advice resulted in better structured pre-deployment preparations as well as the use of real-time

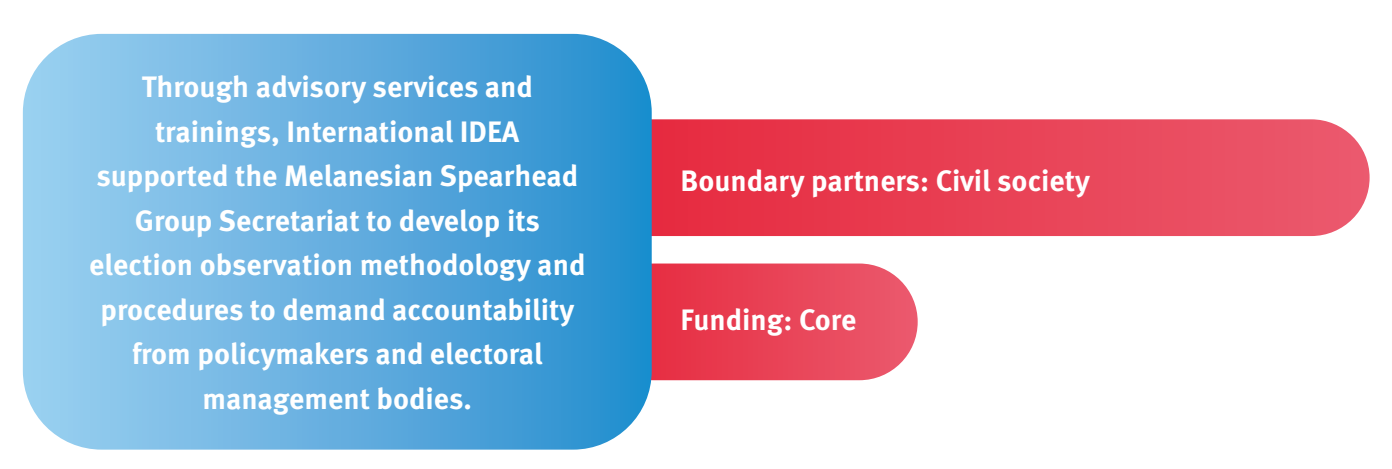

electronic reporting mechanisms, which improved the efficacy of collecting and analysing the observers reports. Consequently, the MSGS requested International IDEA's assistance in drafting the 'MSG Manual for the Conduct of Election Observation in Member Countries', which was submitted in August 2020.

The MSG started observing elections in 2014, but this manual represented the first attempt to adopt a codified observation and reporting procedure.

"The MSG-IDEA partnership is important with respect to the contributions in which, the MSG would like to make to elections and democracy in our region. As such, the MSG looks forward to learning more from IDEA."

- George Hoa'au, the acting Director-General of MSGS

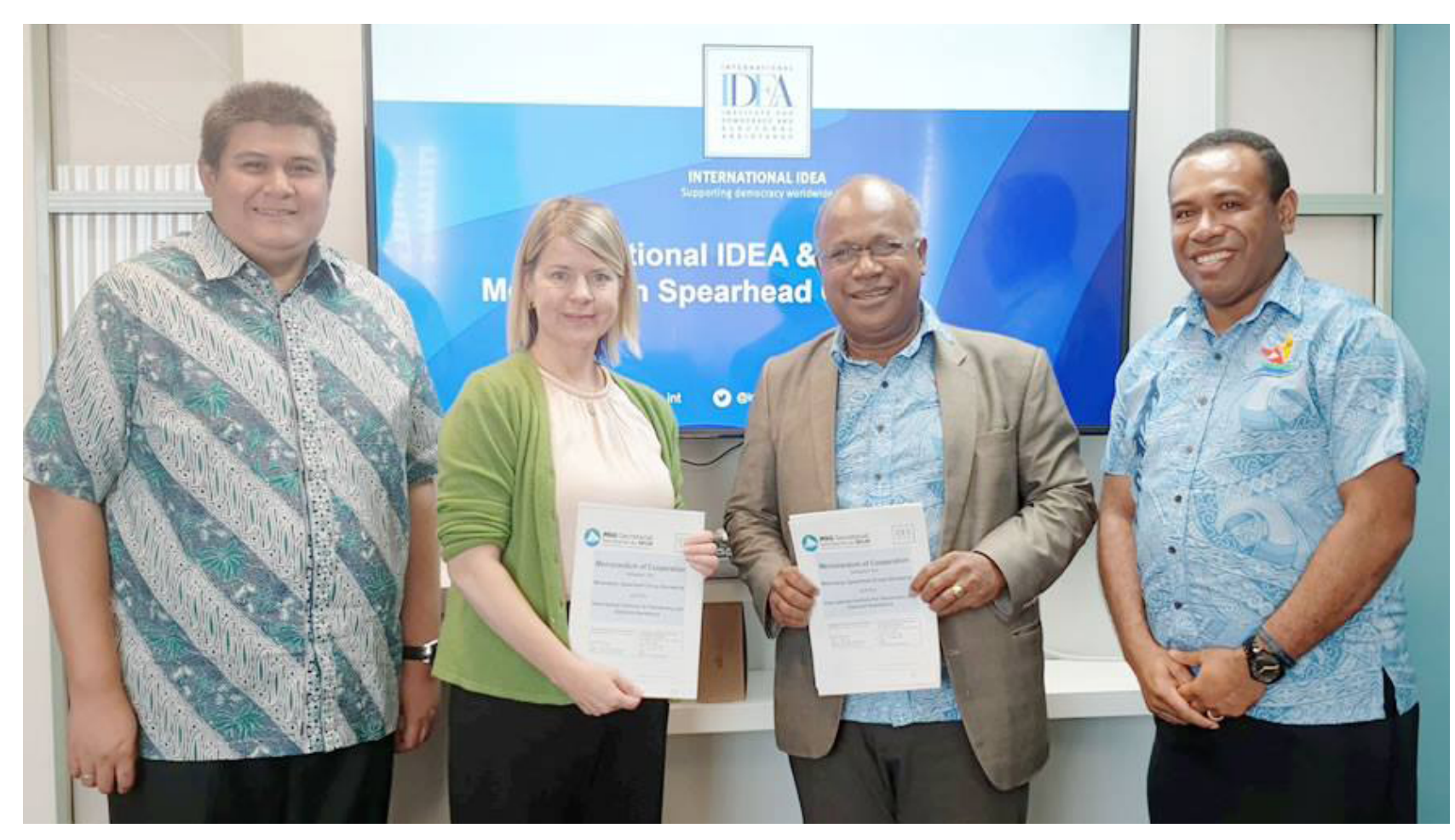

Ambassador Yauvoli at the International IDEA office for Asia and the Pacific in Canberra, Australia. Photo credit: MSGS 


\section{Helping trans citizens vote in Peru}

Measures to reduce trans citizen's exposure to discrimination in the electoral cycle

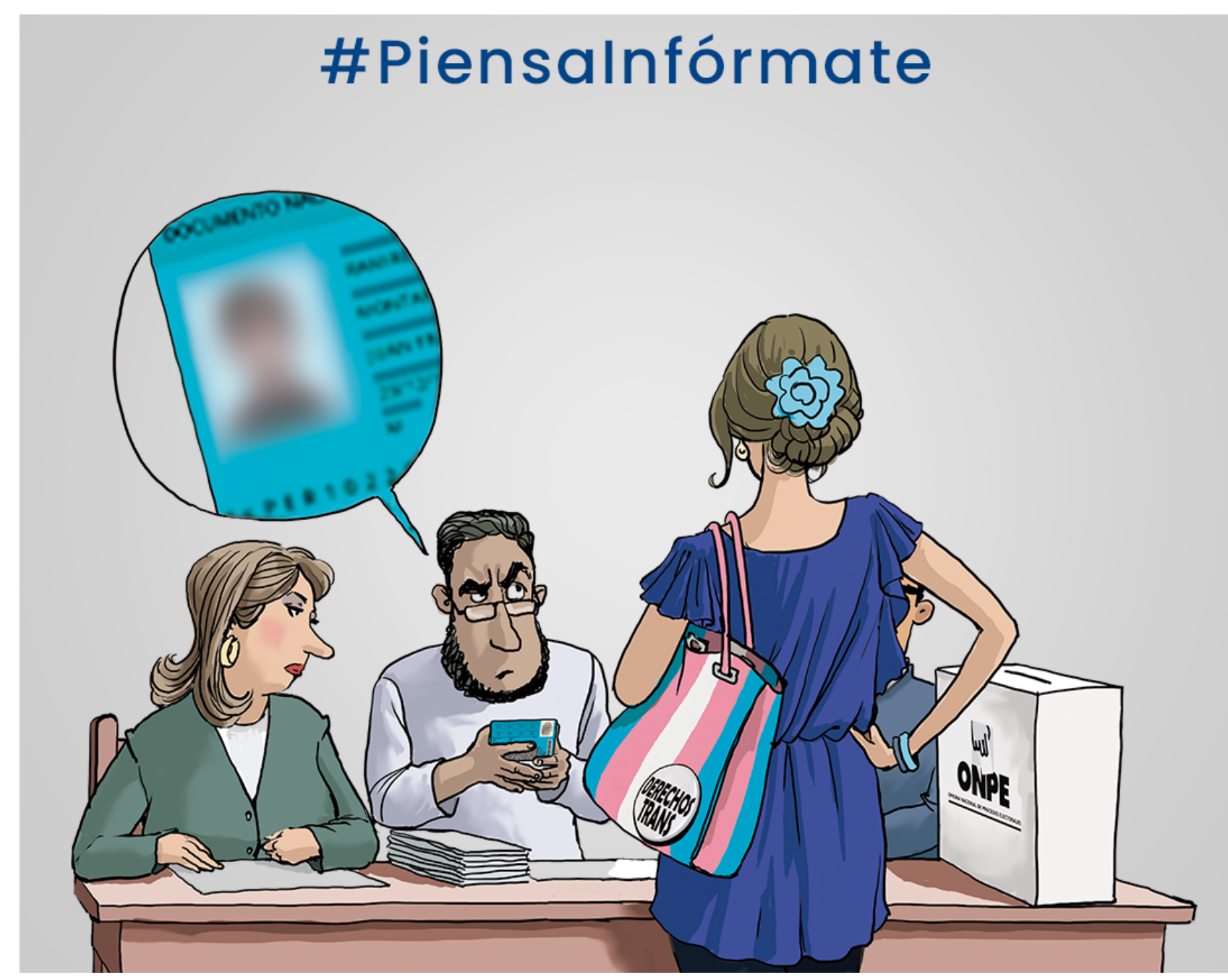

Cartoon and post on Latina's Facebook page published in October 2020. Photo Credit: Latina.pe

Since 2016, International IDEA has been a permanent ally of LGTBIQ organizations that have promoted election monitoring and observation actions. Trans people, because they do not identify with the sex on their identity document and do not fit the expectations and behaviour patterns that society and culture impose on them, suffer social rejection and multiple effects on their fundamental rights.
International IDEA supported the

LGBTIQ community in Peru to advocate

for the principles of impartiality,

integrity, transparency, efficiency,

professionalism and service-

As a result, the National Bureau of

Electoral Processes changed practices.

Boundary partners: Civils society, Electoral management bodies

Funding: USAID, EU

Based on these findings, awareness-raising action was initiated with electoral management bodies (EMBs) to implement Trans voting protocol validation with National Office of Electoral Processes (Oficin Nacional de Procesos Electorales) officials and representatives of trans organizations. To make these initiatives visible, International IDEA teamed with Latina TV, a national media outlet, to create a socia media campaign to spread information about these experiences to a broader audience.

The National Bureau of Electoral Processes in Peru (Oficina Nacional de Procesos Electorales) and International IDEA joined forces to develop a protocol to ensure trans citizens could exercise their right to vote on an equal footing and without discrimination. International IDEA's technical assistance focused on two aspects-(a) providing legal advice to develop an essential document and (b) facilitating the validation of trans organizations.

The establishment of such a protocol will directly affect the expected conduct of all electoral actors (EMB staff, board members, voters, other state entities and citizens in general) in relation to the suffrage of trans voters.

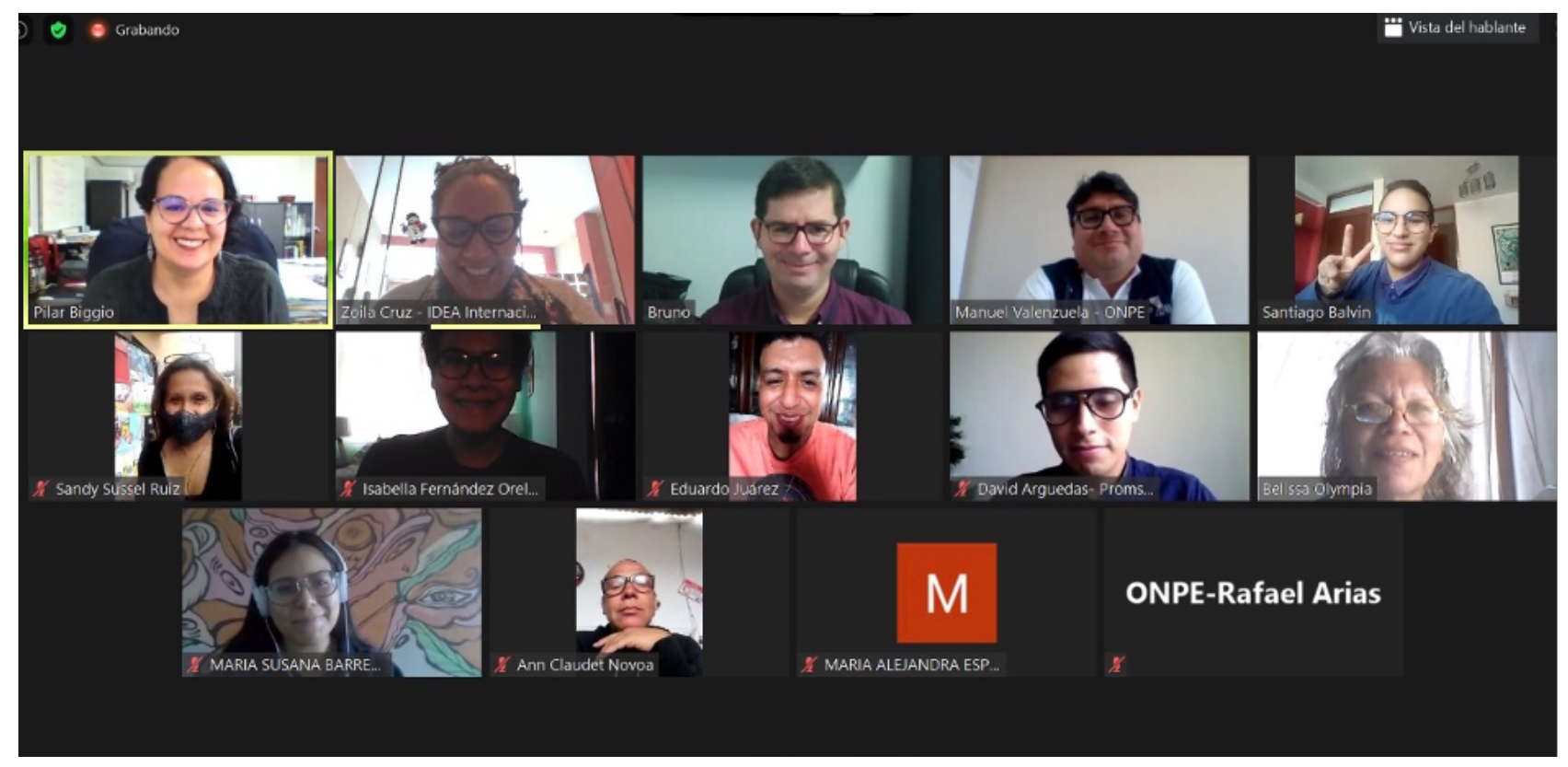

Trans voting protocol validation with National Office of Electoral Processes (Oficina Nacional de Procesos Electorales) officials and representatives of trans organizations. 


\section{Electoral authorities to advance on key policy decisions that address electoral challenges during Argentina's pandemic}

\section{Evaluating the impact of Covid-19 on the 2021 electoral process}

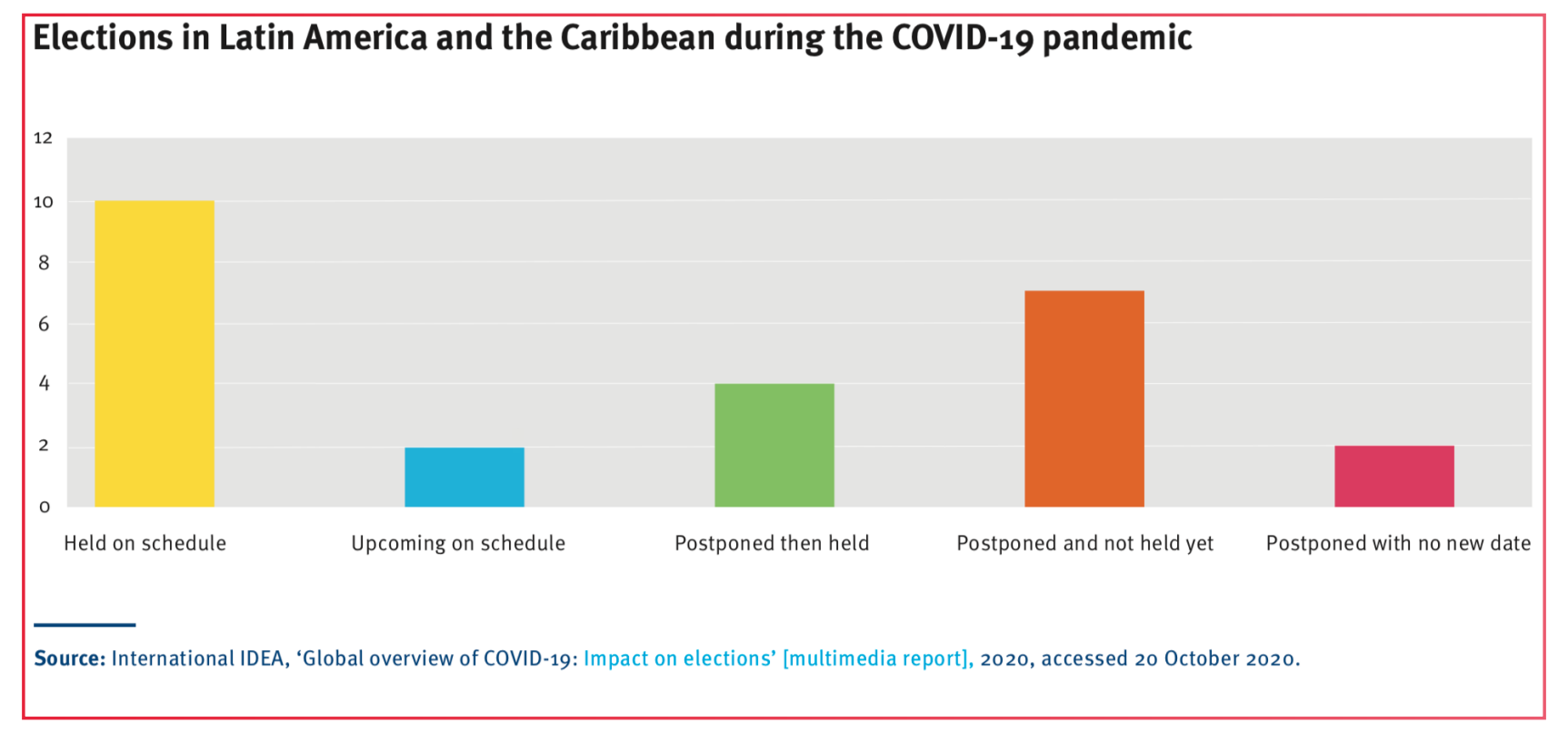

The Covid-19 pandemic forced many institutions that organize elections to adapt. According to data from International IDEA, only 48 elections were held as initially planned in 2020; at least 67 countries and territories postponed national and subnational elections because of the pandemic.

Electoral processes involve multiple stages or phases, each of which requires planning and preparation. Budget planning and the execution of administrative and contractual procedures in Argentina begin at least one year before the election. In Argentina, 2021 marks the beginning of a new electoral cycle, in which national legislative elections, provincial legislative elections in 11 districts, and the election of two governors are scheduled.
Therefore, it is essential to conduct a forecasting exercise to analyse which aspects of Argentina's electoral administration need to be adapted to the pandemic and postpandemic context.

The 'Elections in Times of the Pandemic in Argentina' project is jointly organized by International IDEA and the Center for the Implementation of Public Policies for Equity and Growth.

The project evaluates the impact of Covid-19 on the 2021 electoral process. It proposes adaptations to electoral administration to ensure voter safety from a public health perspective while guaranteeing the full exercise of political rights.

The collaboration produced a public policy document that systematically reviews the international experience of elections held during the pandemic as well as the good practices identified by international organizations regarding electoral administration.

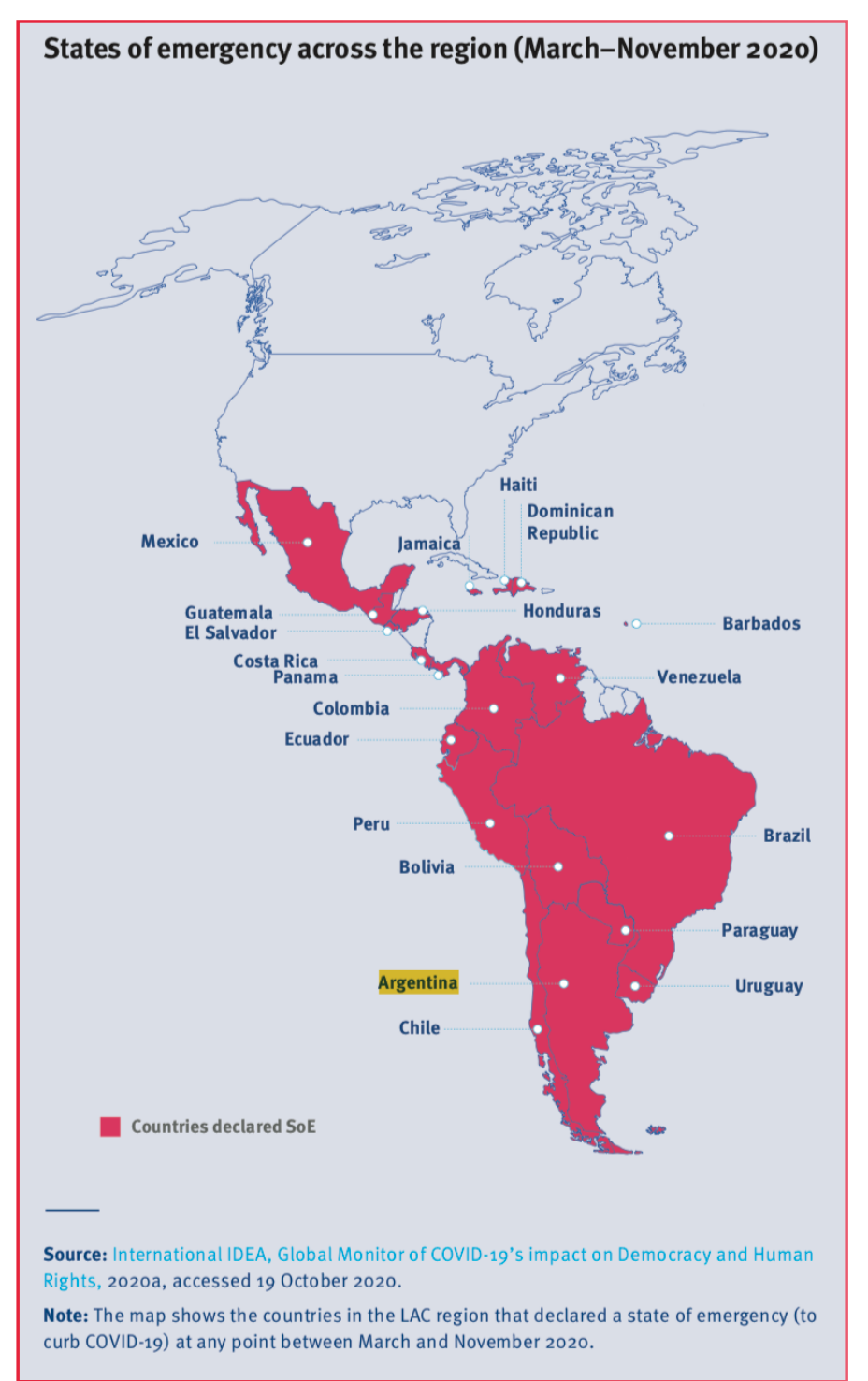




\section{From the sidelines to centre stage: Bangsamoro young people ready for their future}

Supporting youth through online learning sessions on democratic principles

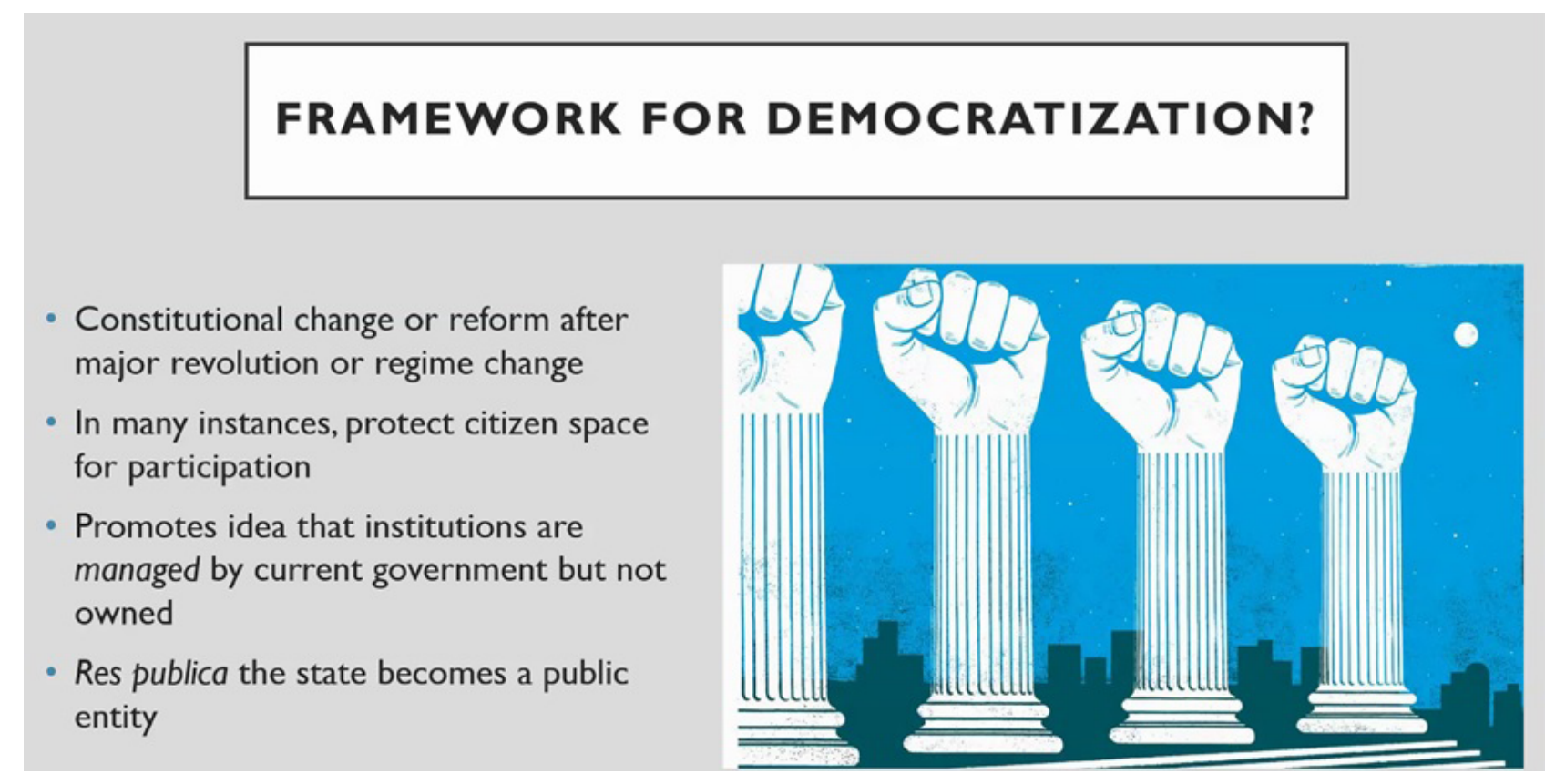

Young people are often sidelined from participating in political processes, and Filipino youth's engagement in formal governance platforms is weak. Youth in the Bangsamoro Autonomous Region in Muslim Mindanao are particularly vulnerable and marginalized due to the region's history of conflict.

During the Covid-19 pandemic, International IDEA has been supporting youth through online learning sessions designed to enhance their knowledge of democratic principles, institutions and processes and how they apply to their role in the Bangsamoro transition. The learning sessions' content and format were inspired by the International IDEA's Youth Democracy Academy.

The region expects to hold its first parliamentary elections as early as 2022 .

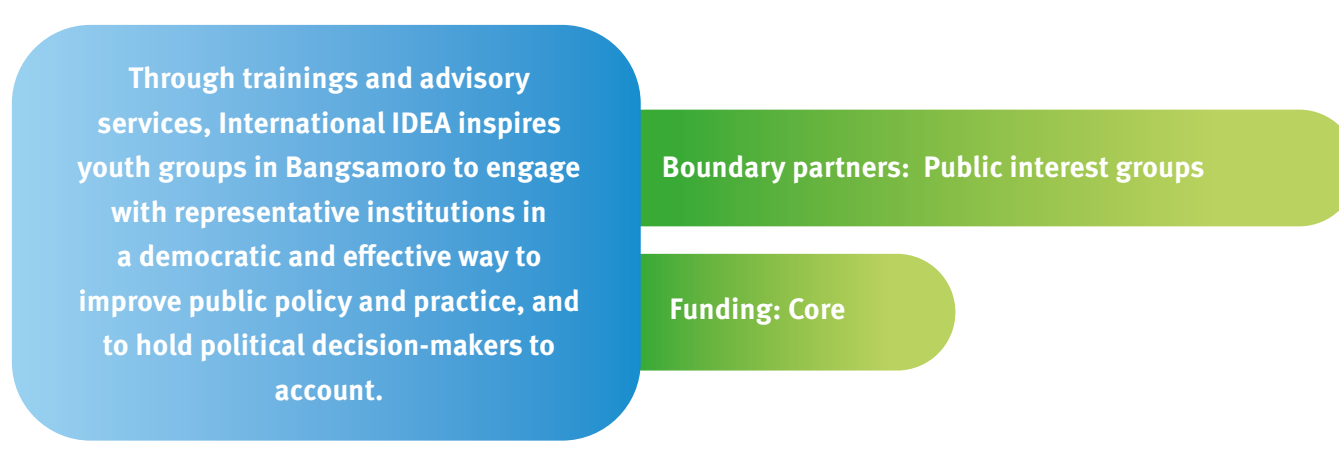

Youth representation in the Bangsamoro legislature is possible with reserved seats allocated for nonMoro indigenous peoples and settler communities and sectoral representatives allocated for women, youth, traditional leaders and Islamic religious scholars.

Participants showed immense interest through discussions in each online session and shared their own experiences. They agreed on the importance of such learning opportunities and their role in political party building and strengthening the

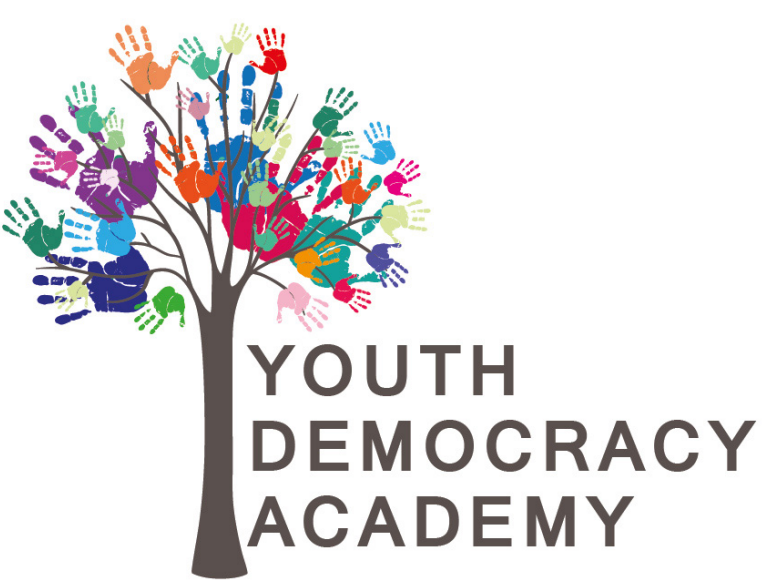
region's democratic institutions and processes.

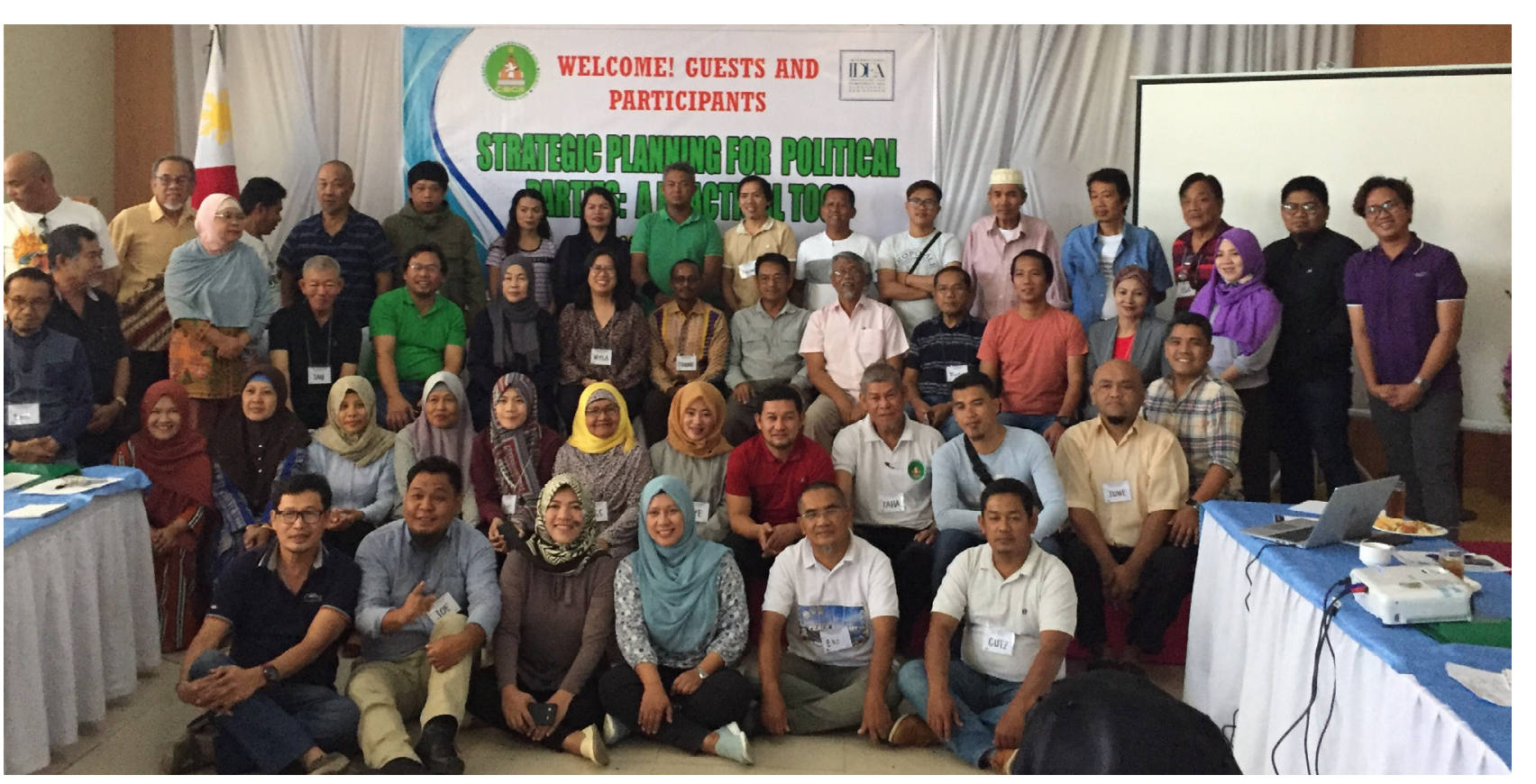




\section{Partnering for online political advertising and microtargeting reforms in Europe}

International IDEA increases its work on online political advertising and microtargeting

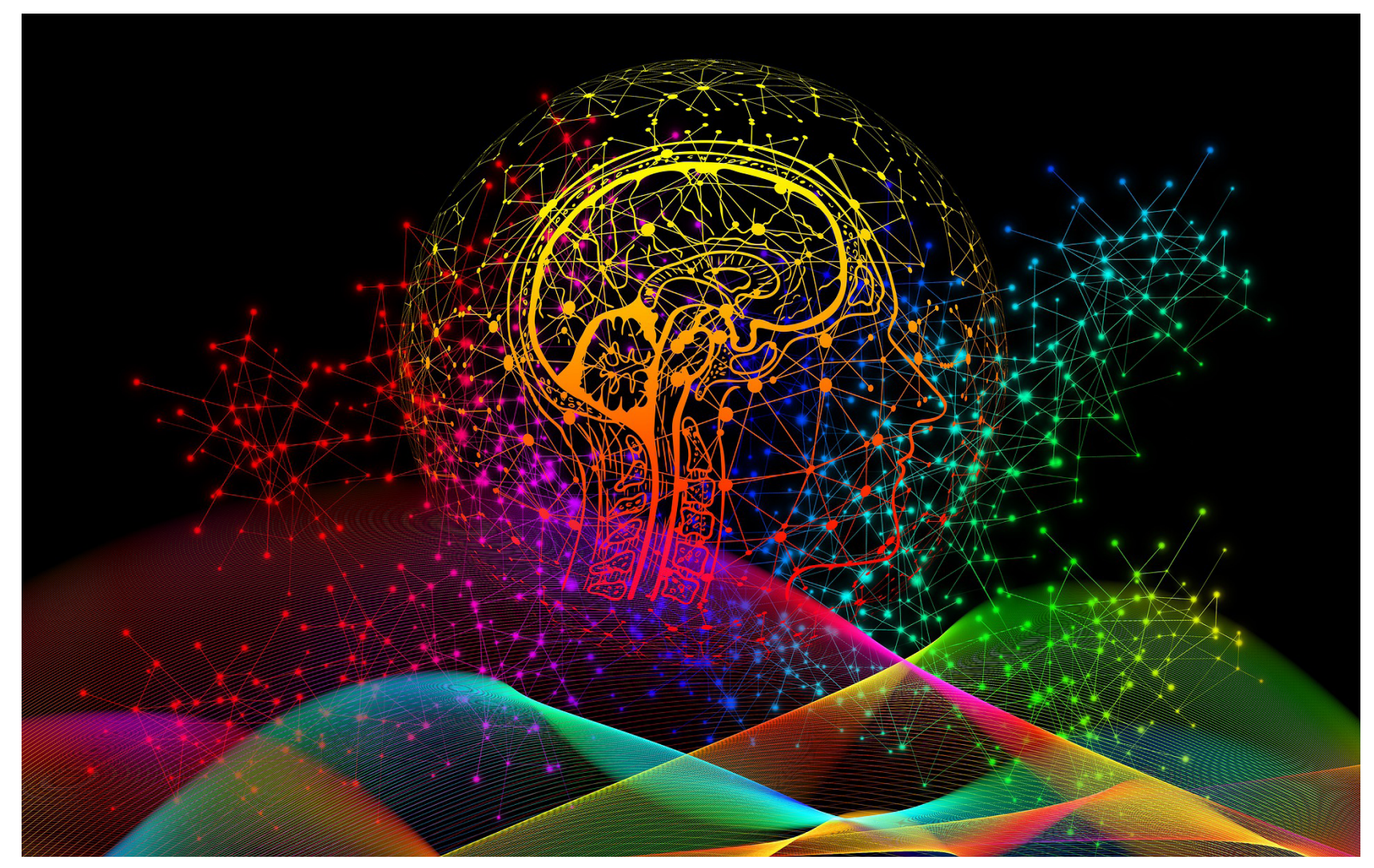

An important part of the democratic debate takes place in the online sphere, but many countries struggle to apply regulatory frameworks in this arena. Frameworks to regulate and oversee online political advertising and microtargeting are still in their infancy. In 2020, International IDEA increased its work on online political advertising and microtargeting.

As part of International IDEA's work on this issue, a June 2020 webinar series co-organized by the European Commission and the Dutch Ministry of Interior and Kingdom Relations focused on the understanding,

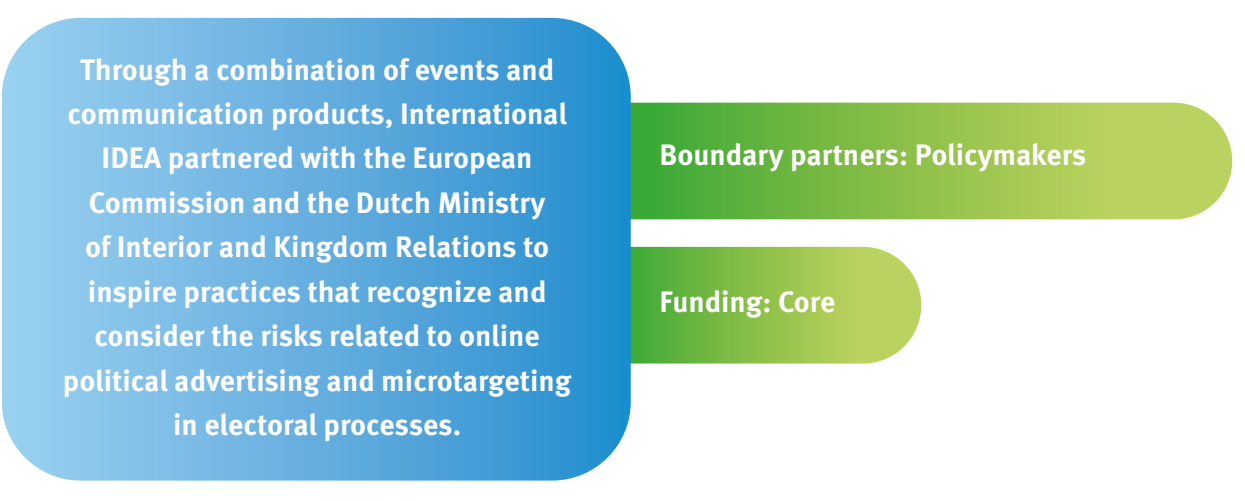

regulation and oversight of online political advertising and microtargeting. It gathered European Union (EU) officials, oversight bodies from 24 countries, and academic and civil society experts. The Regional Europe Programme subsequently submitted a position paper to the EU's online public consultation on the European Democracy Action plan, including recommendations covering the main takeaways from the webinar series. On 4 December, the EU released the Action Plan, in which online political advertisement was a central theme. By partnering with EU and an IDEA EU Member State, International IDEA gained authority and credibility for its work on the topic. The topic of online political advertising has become a top reform priority across Europe.

In November 2020, the Dutch Ministry of Interior and Kingdom Relations invited REP to lead the development of a Code of Practice for social media companies and political parties to help ensure the integrity of the 2021 elections in the online sphere. Besides recent expertise on online political advertising, this work will build on the Institute's experience with similar codes in Latin America and elsewhere.

ONLINE POLITICAL ADVERTISING AND MICROTARGETING: THE LATEST LEGAL, ETHICAL, POLITICALAND TECHNOLOGICAL EVOLUTIONS

AND

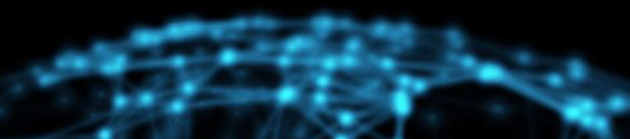

VIRTUAL MEETING OF THE EUROPEAN COOPERATION NETWORK ON ELECTIONS

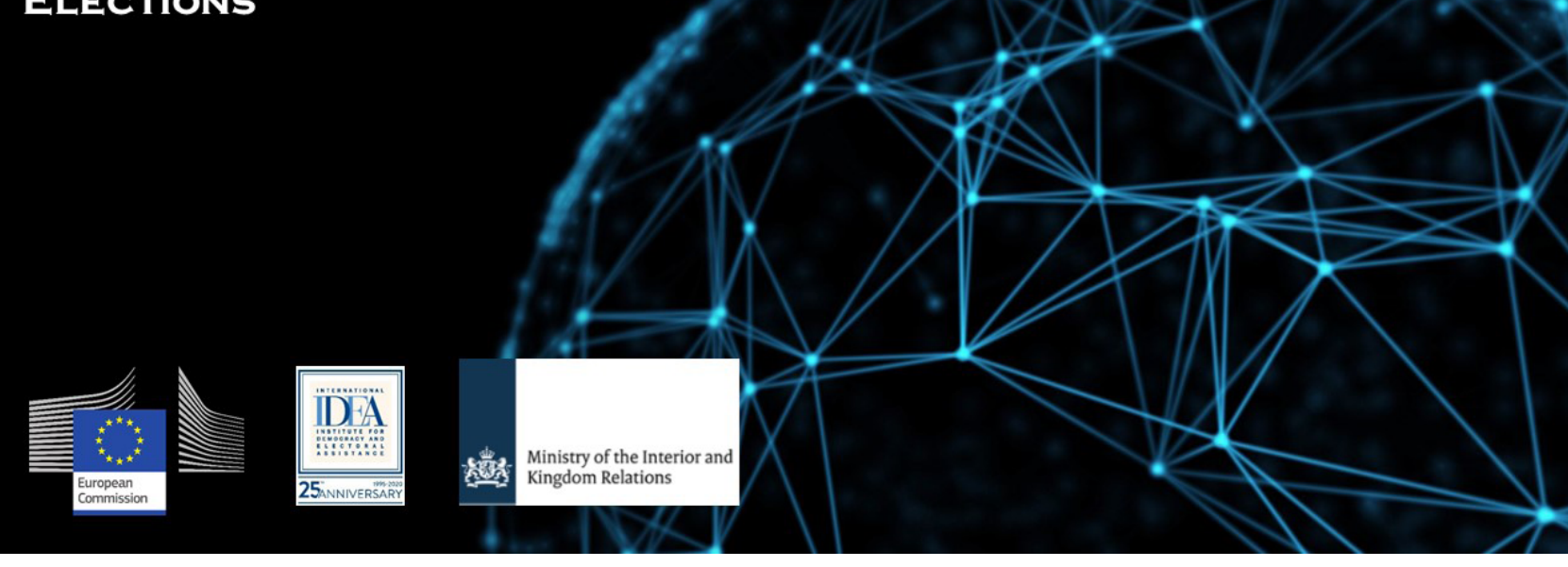




\section{Bringing gender violence against women in politics into focus in Paraguay}

\#NoaLaViolenciaPolítica - Paradigm shifts in the making

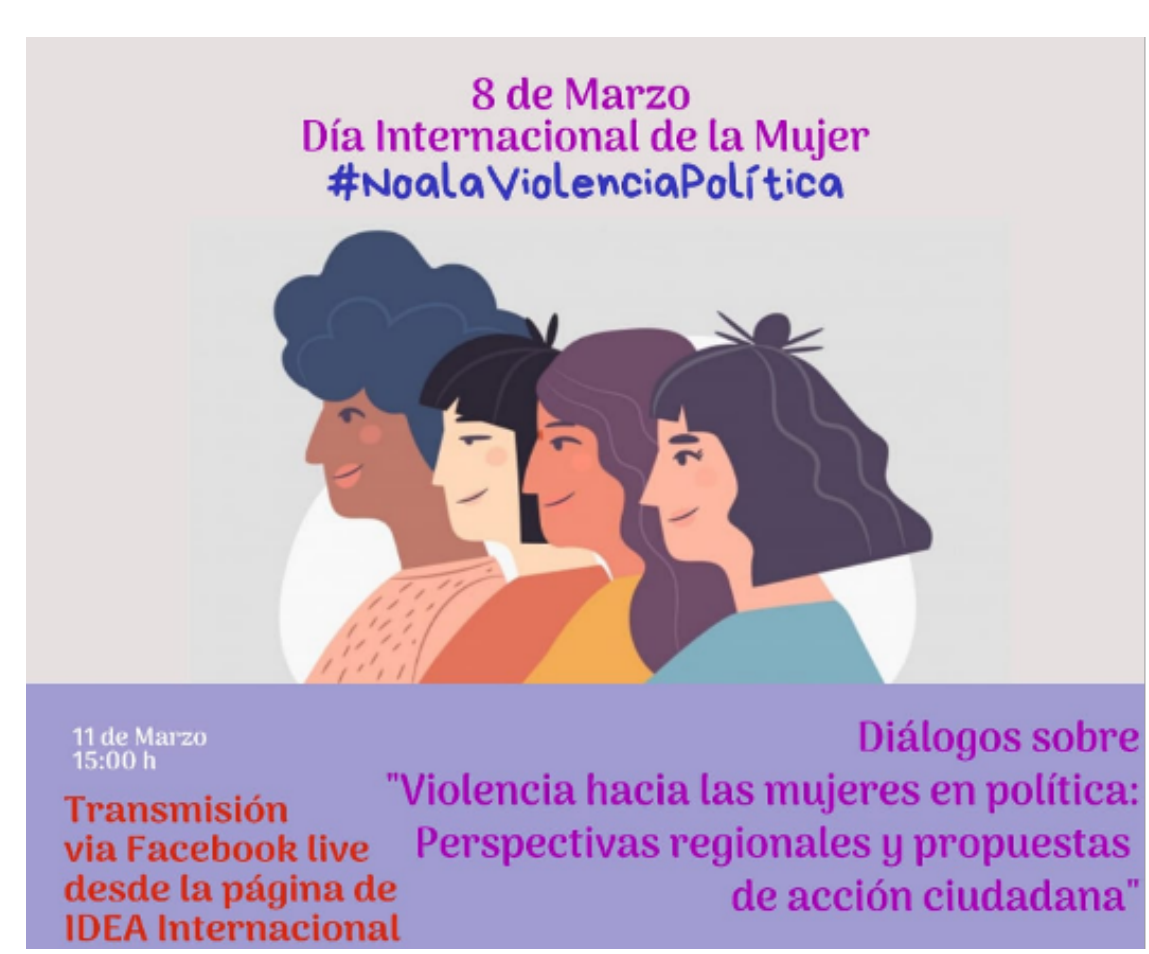

Violence against women in politics (VAWP) has yet to be recognized and discussed in Paraguay. It affects women in the active exercise of their political rights, and thus violates their human and constitutional rights. Gender-based violence in politics is one of the most widespread and naturalized manifestation of violence towards women.

This form of gender-based discrimination impedes women's full recognition as political subjects, and discourages many women in Latin America from pursuing political careers.

Women's political representation is lagging in Paraguay after 31 years of democracy. Women obtained the right to vote only in 1961, making it the last country in the region to grant voting rights to women. Following the 2018 elections, there is 16 per cent female representation in the National Congress (18 per cent in the Chamber of Senators and 15 per cent in the Chamber of Deputies). A similar trend of under-representation is observed at the local level, with 10 per cent female mayors and 23 per cent female municipal councillors.

Starting in 2019, and in the framework of the EU-funded project 'Consolidation of Paraguayan Democracy II', International IDEA spearheaded a series of initiatives designed to mitigate VAWP. The Institute has effectively joined efforts with local stakeholders to highlight the problem and make it an active part of the agenda of strategic stakeholders, such as the Equity and Gender Commission of the Senate, the Superior Electoral Tribunal, the Ministry of Women, political parties and civil society.

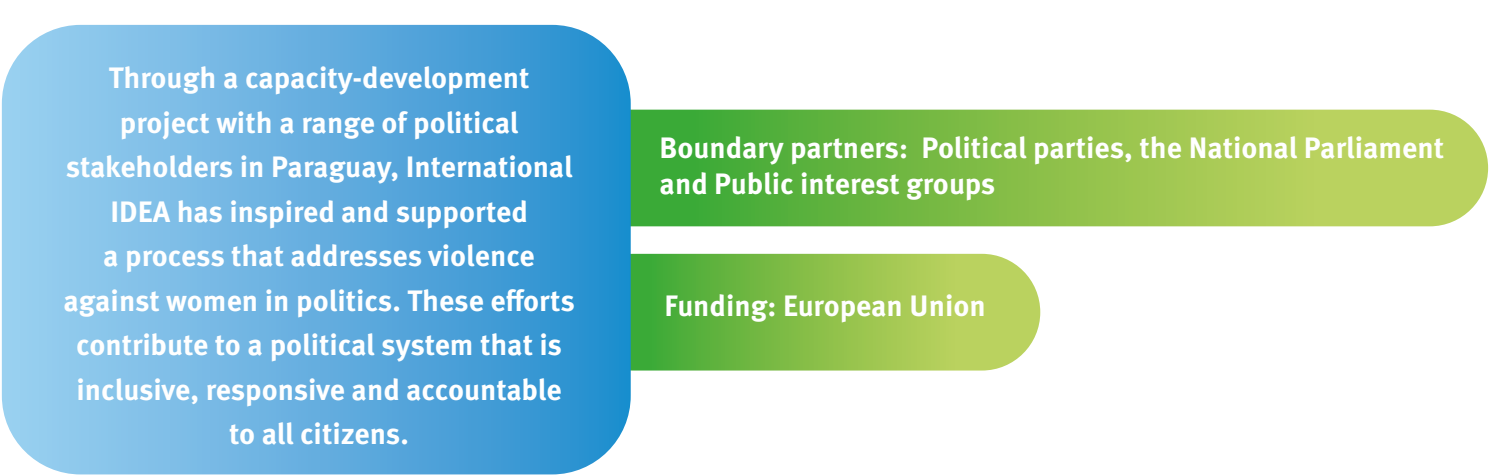

Five international seminars and webinars were organized during the project's first year, reaching over 2,500 people. These have started an important political conversation, substantive debate and sensitization to introduce the concept of VAWP into the social discourse and emphasize the need for specific legislation and regulation.

These joint efforts are beginning to yield tangible results. The Senate's Equity and Gender Commission, which has received International IDEA technical assistance, is now discussing the details of a VAWP bill, which is expected to be submitted to the legislative process for debate and vote during 2021 .

The commission is also currently designing an internal protocol for managing harassment and violence cases in the Senate. In parallel, International IDEA is supporting a discussion between key stakeholders, including the Ministry of Women, the Superior Electoral Tribunal and civil society women's organizations, on creating an observatory on VAWP to record, analyse and follow up cases of violence against women in the run-up to the 2021 municipal elections.

We believe these are paradigm shifts in the making. Cultural change takes time, but it is certainly made of building blocks like these-advancing gender equality and safeguarding human rights in democracy one solid step at a time.

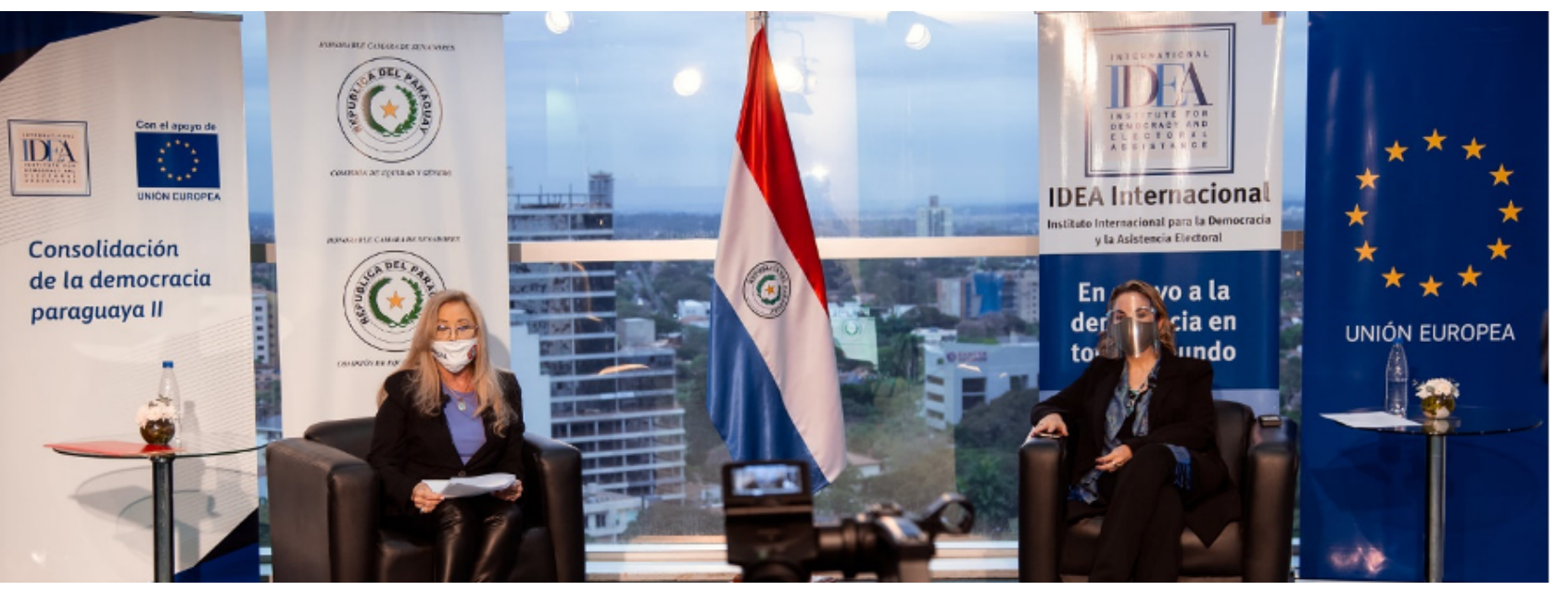

Senator Mirta Gusinky, Chair of the Equity and Gender Commission of the Paraguayan Senate; and Lourdes González-Prieto, Head of International IDEA's Paraguay Programme, during an online round-table on violence against women in politics, held in September 2020. Photo credit: International IDEA 


\section{Supporting political finance reforms in Commonwealth countries}

A solid foundation for evidence-based political finance reforms

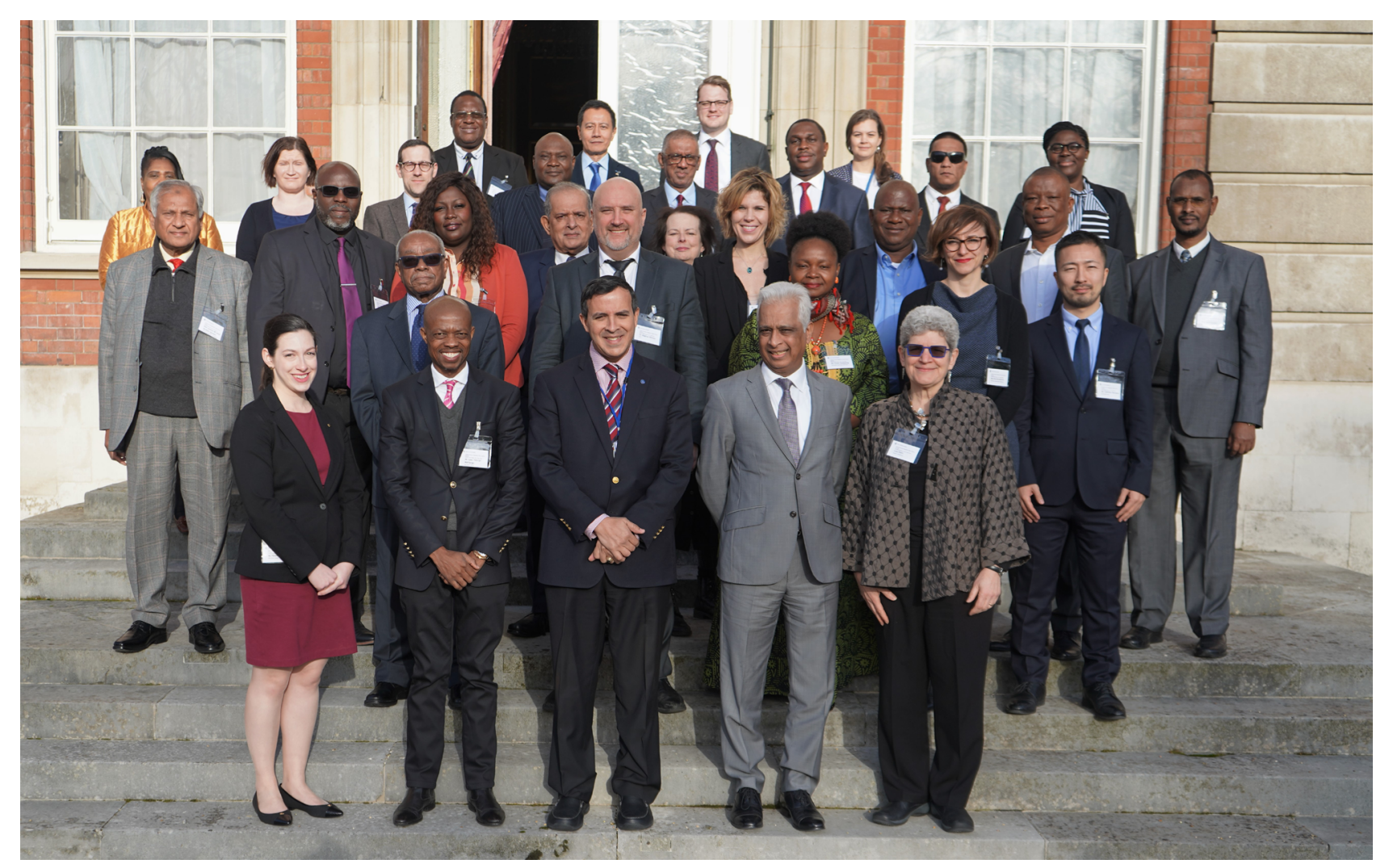

Participants of an Expert Review Meeting on Commonwealth legislative approaches to political finance regulation, organized by the Commonwealth Secretariat in London on 10-11 February. Photo credit: The Commonwealth Secretariat

The Money in Politics Programme provided comparative political finance data and analysis to the Commonwealth Secretariat to facilitate its review of political finance legislative frameworks in 24 member countries. International IDEA was also invited to the Expert Review Meeting in London on 10-11 February to provide technical expertise and review the draft report.

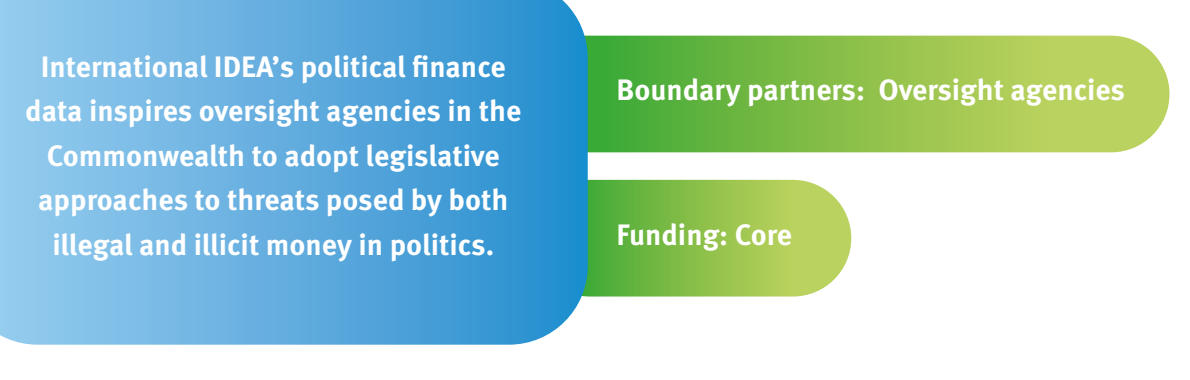

The review provided a solid foundation for evidence-based political finance reforms in Commonwealth member countries. International IDEA pointed out several critical issues that require further improvement. For example, according to the Institute's Political Finance Database, just 40.4 per cent of Commonwealth countries require political finance reports to be made public, compared to the global average of 60.1 per cent.

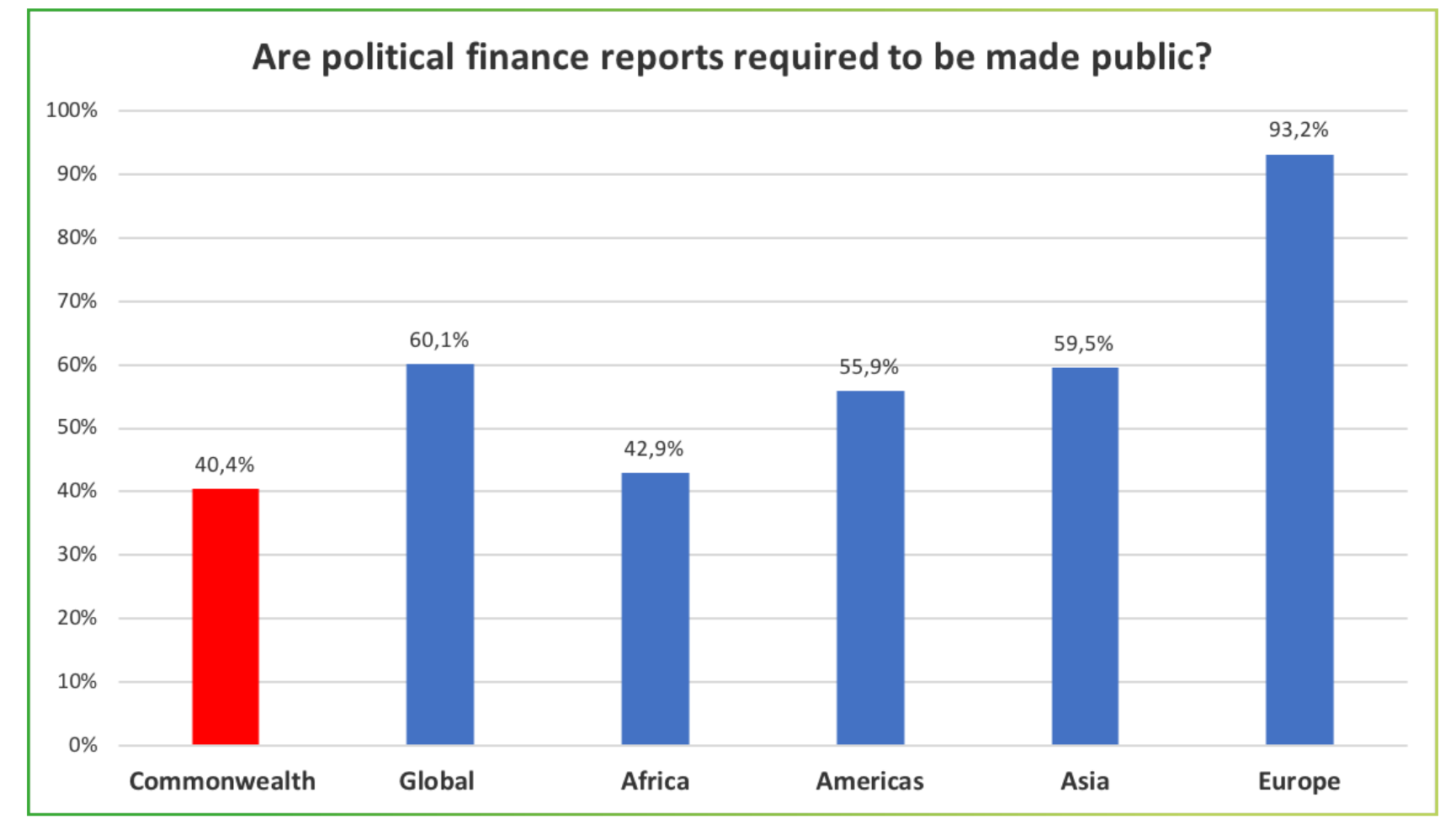




\section{Making a virtue of virtuality: legislative drafting knowledge exchange with the Parliament of Bhutan}

\section{A strengthened legislative process}

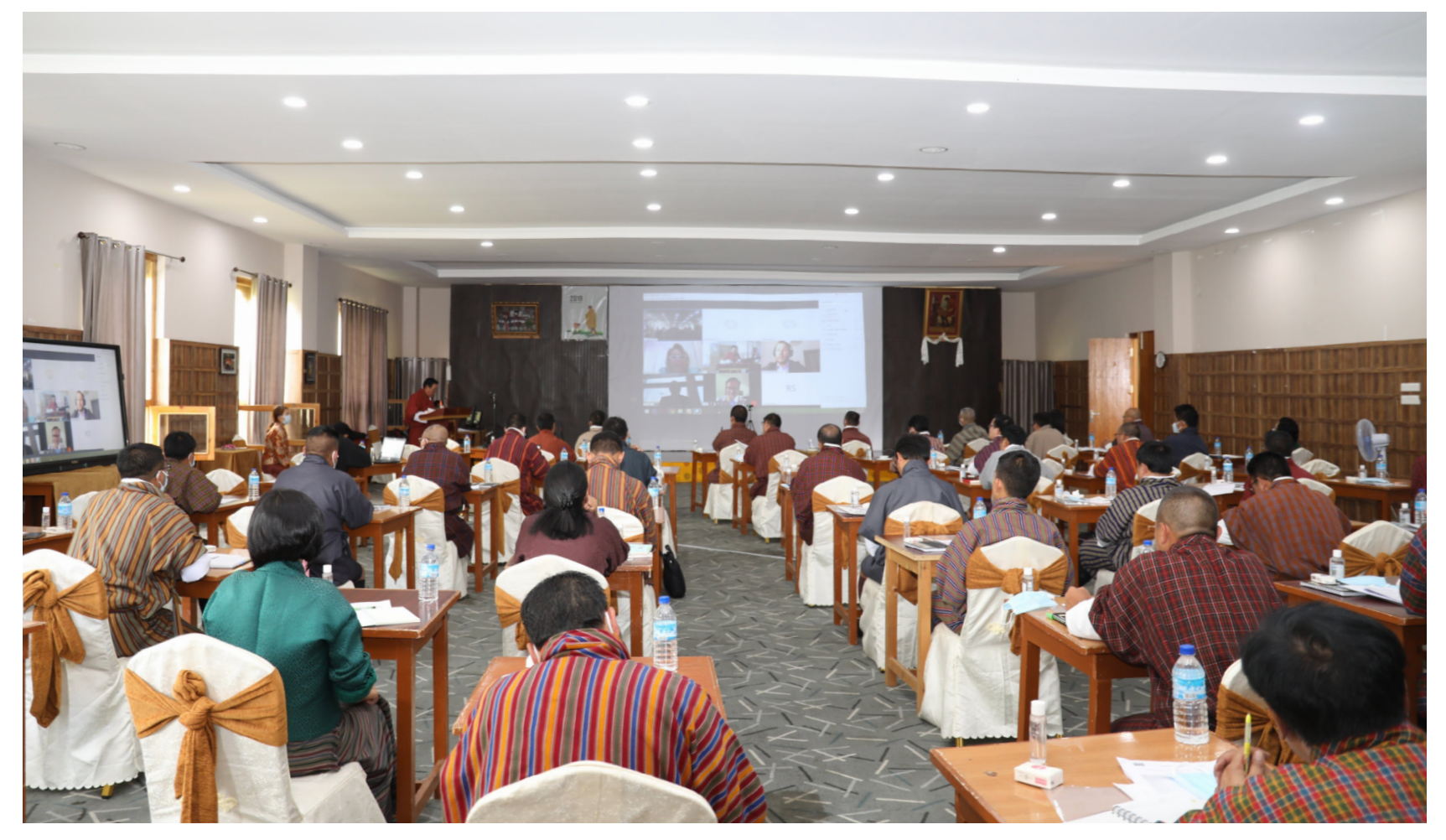

Hybrid legislative drafting seminar with the Parliament of Bhutan, 3-7 August 2020.

The Parliament of Bhutan requested peer-to-peer support from INTER PARES, an EU-financed project implemented by International IDEA, to strengthen its legislative drafting skills. Before the pandemic, INTER PARES had planned to support this request through two-way in-person exchanges between European Union (EU) national parliaments and Bhutan.

Due to Covid-19 travel restrictions, International IDEA instead offered an online workshop that covered the key aspects of legislative drafting.

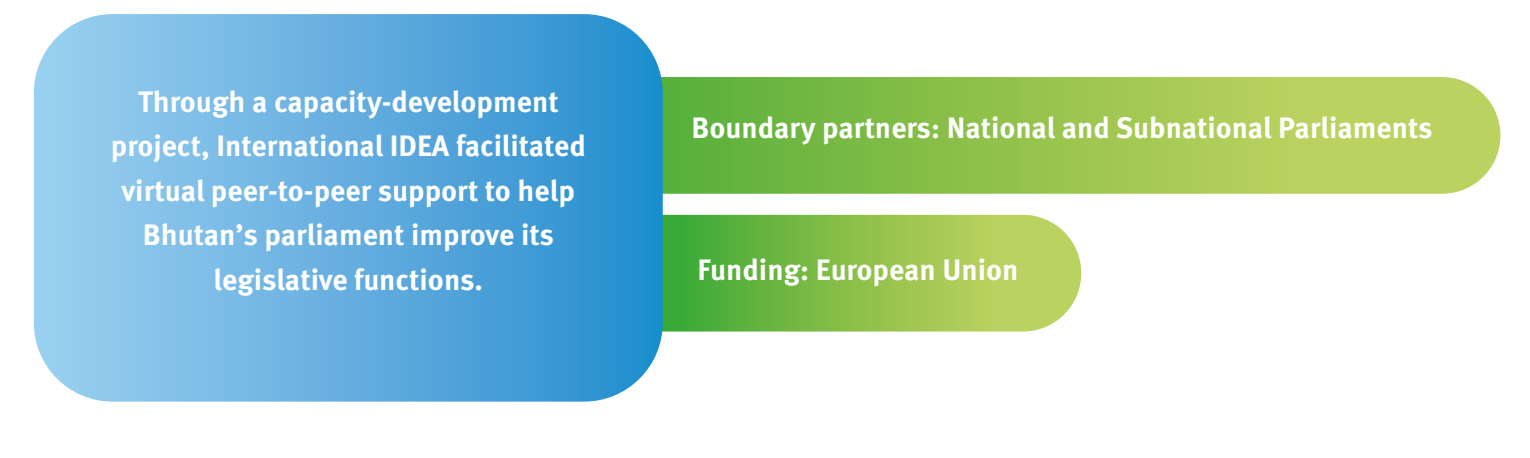

The workshop involved 60 Members of Parliament and staff from the Parliament of Bhutan and experts from European national parliaments including those of the Czech Republic, Greece, Ireland, Poland and Slovakia, as well as representatives of the EU. This support enabled the Parliament of Bhutan to address its identified priorities to strengthen its legislative process to avoid situations in which there may be no consolidated version of legislation, which in the past has caused confusion among judges applying the law.

This virtual meeting proved to be a very effective format. The parliaments of the Maldives and The Gambia have asked INTER PARES to develop similar legislative drafting courses.

This approach, which was initially developed through necessity, has become a successful new means of delivering effective support.

Photo credits: INTER PARES

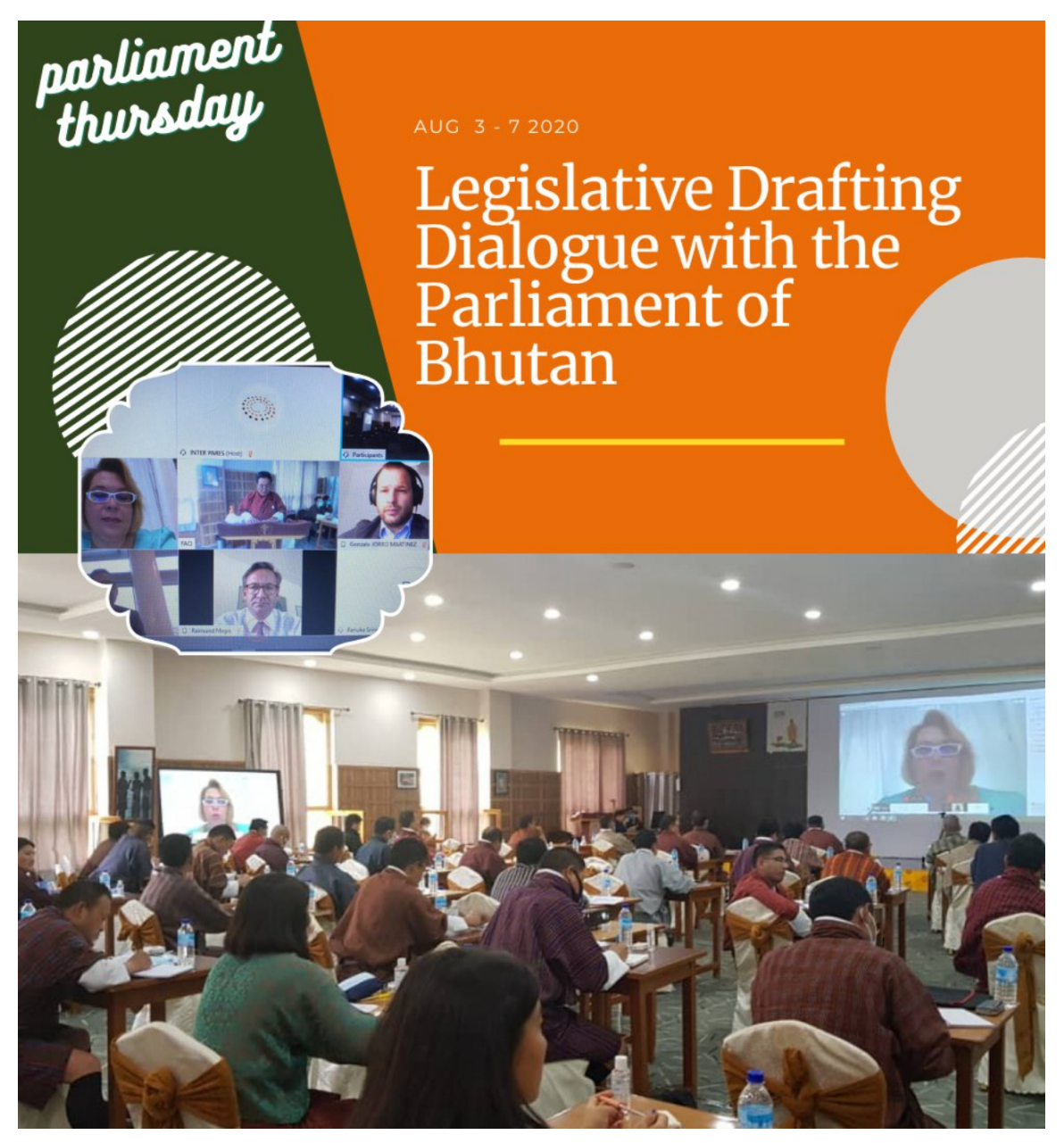




\section{Renewing the AGORA Parliamentary Development Web Portal}

E-courses on parliamentary oversight, and parliaments and climate change

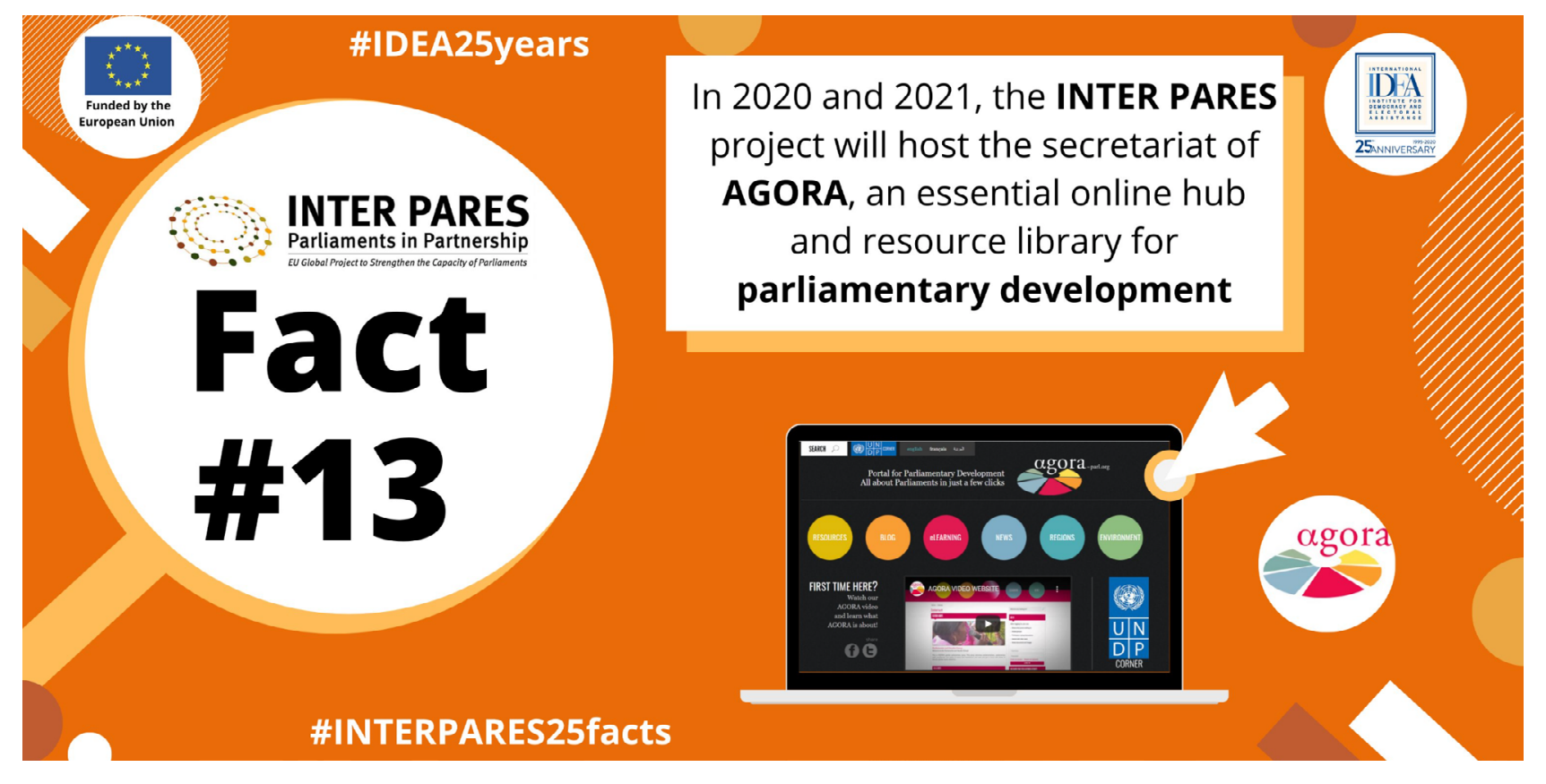

In December 2020, INTER PARES, an EU-financed project implemented by International IDEA, launched two new parliamentary e-courses on AGORA - the only global online knowledge hub on parliamentary development—on parliamentary oversight, and parliaments and climate change. Six additional e-learning courses will be rolled out in 2021.

Building on its past success as a platform with a transcontinental reach, AGORA is also launching versions in Arabic, French, Portuguese and Spanish in 2021. AGORA will further expand the platform in 2021 by including themes related to parliamentary development.

AGORA partners have agreed that the first online global Parliamentary Development Community of Practice will be organized in early 2021. The conference will broaden participation beyond long-time

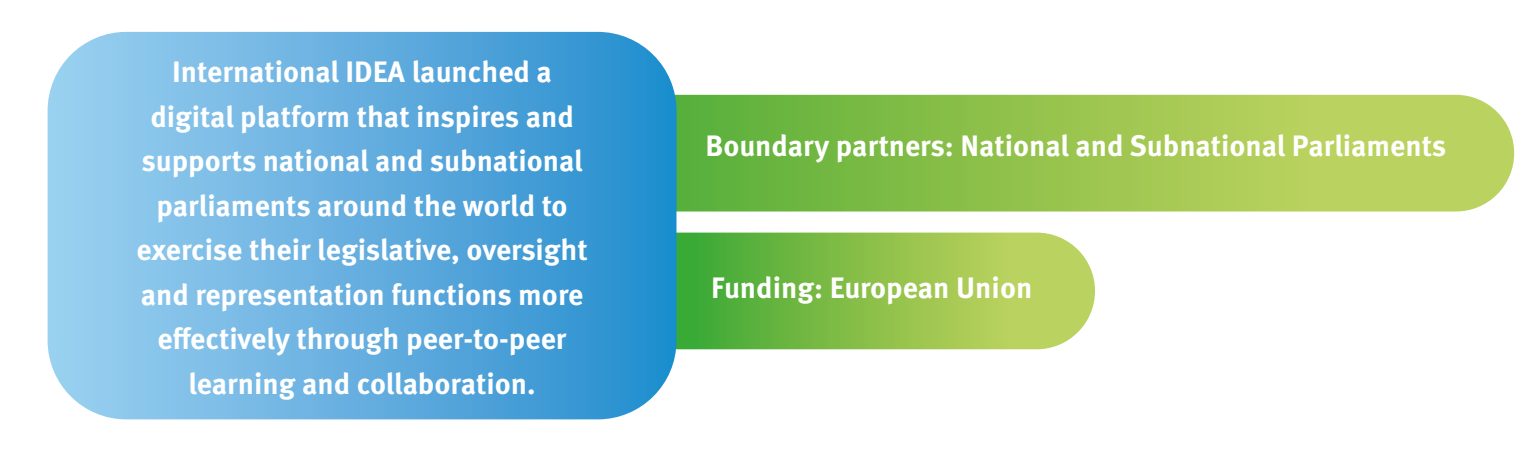

parliamentary development organizations to engage the international development units of national parliaments, as well as scholars working on parliamentary development topics.

The renewal and relaunch of AGORA has therefore not only enhanced this valued parliamentary development resource. It has also enabled the portal to serve as a platform for a revitalized community of practice, thus enabling innovation, collaboration and learning to benefit parliaments and strengthen democracy around the world.

There were over 105,000 users in the first 10 months of 2020, compared with 94,866 during the whole year of 2019.

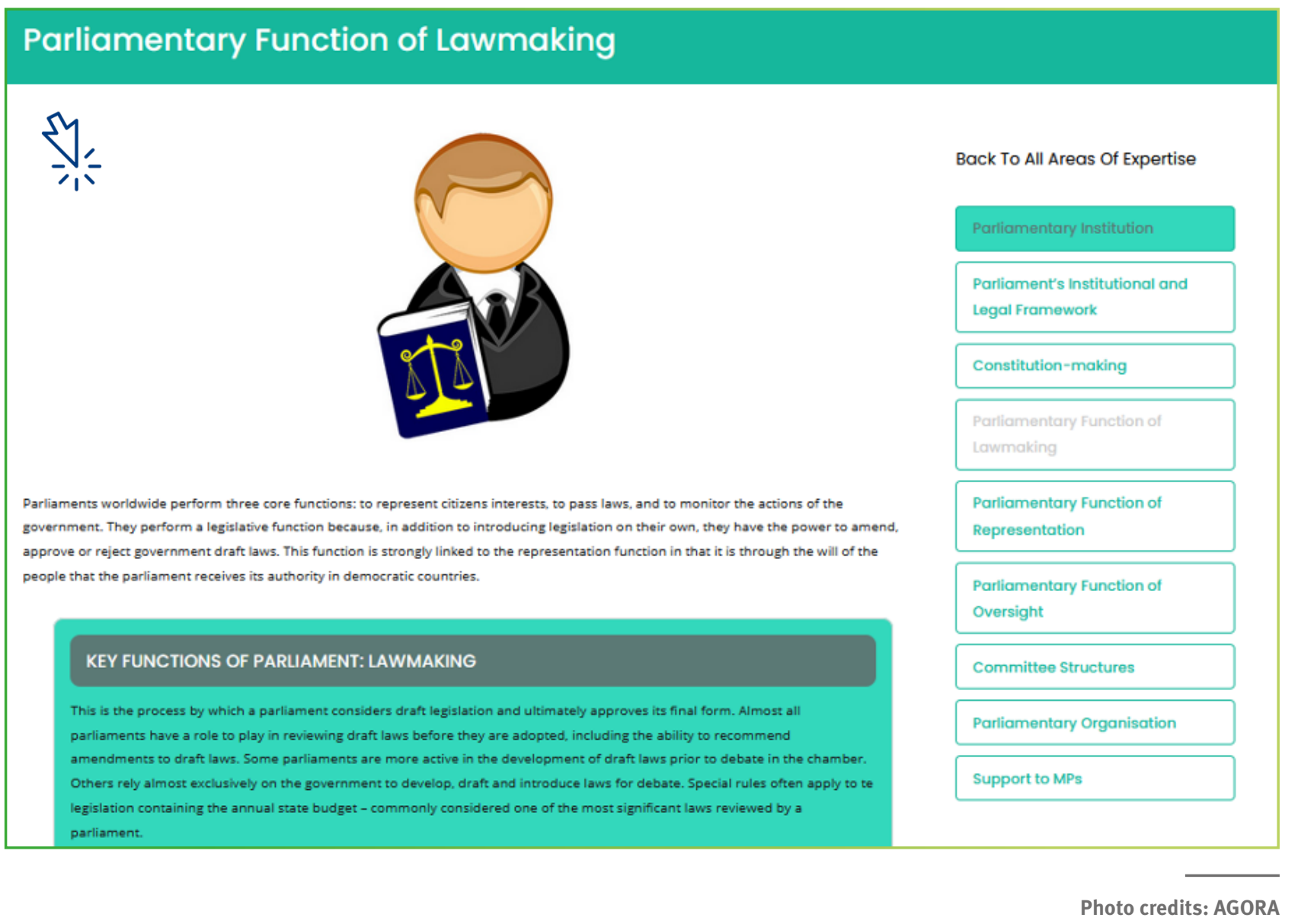




\section{Supporting Nepal's locally elected representatives in understanding deliberative decision-making}

A mentoring approach to assist elected representatives

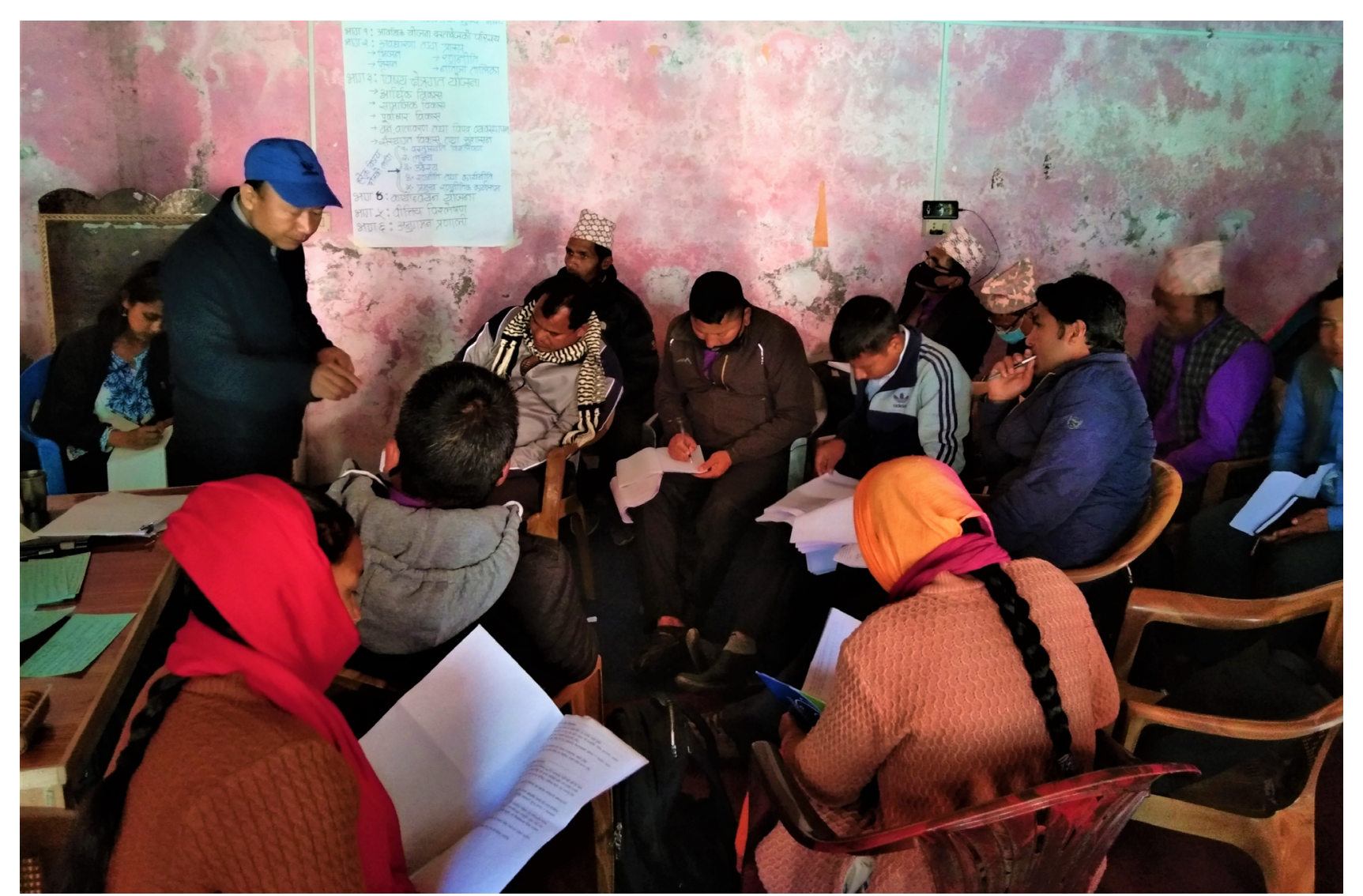

Sanibheri Gaunpalika Periodic Planning Workshop facilitated by the International IDEA team. (Both Photos)

To promote the practice of deliberative decision-making in local governance, the Coherence programme-a joint programme of the Ministry of Federal Affairs and General Administration, the UK Foreign Commonwealth and Development Office, and International IDEA—was created to promote political coherence within the Nepali system. Focused on local and provincial government systems, the programme has been piloting a mentoring approach to assist elected representatives in finding political coherence in
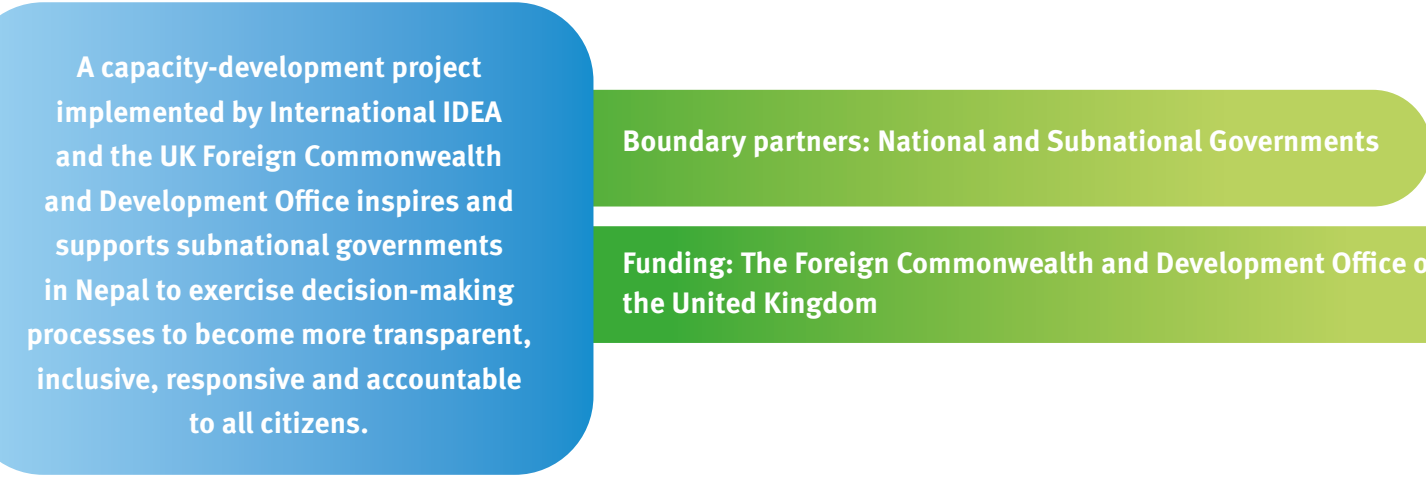

Funding: The Foreign Commonwealth and Development Office of

the United Kingdom

various local governance processes through deliberation. Young graduates complete an intensive onemonth induction and are deployed to palikas (local governments in Nepal), where they provide ongoing hand-holding support as opposed to periodic trainings/workshops.

The four-person mentor team has been in Sanibheri Gaunpalika, a remote palika in the West Rukum district of Karnali province. The palika hired a consultant to prepare its periodic plan-a document required by the federal government for the planned development of palikas.

This multiyear plan is supposed to guide the palika to use its available resources in a systematic and sustainable way to obtain optimum results through the annual plans. However, since the document was prepared by a private firm without proper consultation with the elected representatives of the palika, they sought the International IDEA-trained mentor team's support to revise it.

In a three-day workshop facilitated by a planning expert who had completed the Coherence programme's mentor-plus training, the executive members of the palika, with support from sectoral officials, were encouraged to jointly identify the palika's problems, requirements and priorities and allocate the necessary resources through a deliberative process.

The participants realized that rigorous discussion backed by evidence and data is crucial before making any decisions on the sustainable use of resources. 'We had never done anything like this before' the palika chair said. The chair explained that these discussions were the best he had ever experienced in the palika, largely because they were fully owned by the participants.

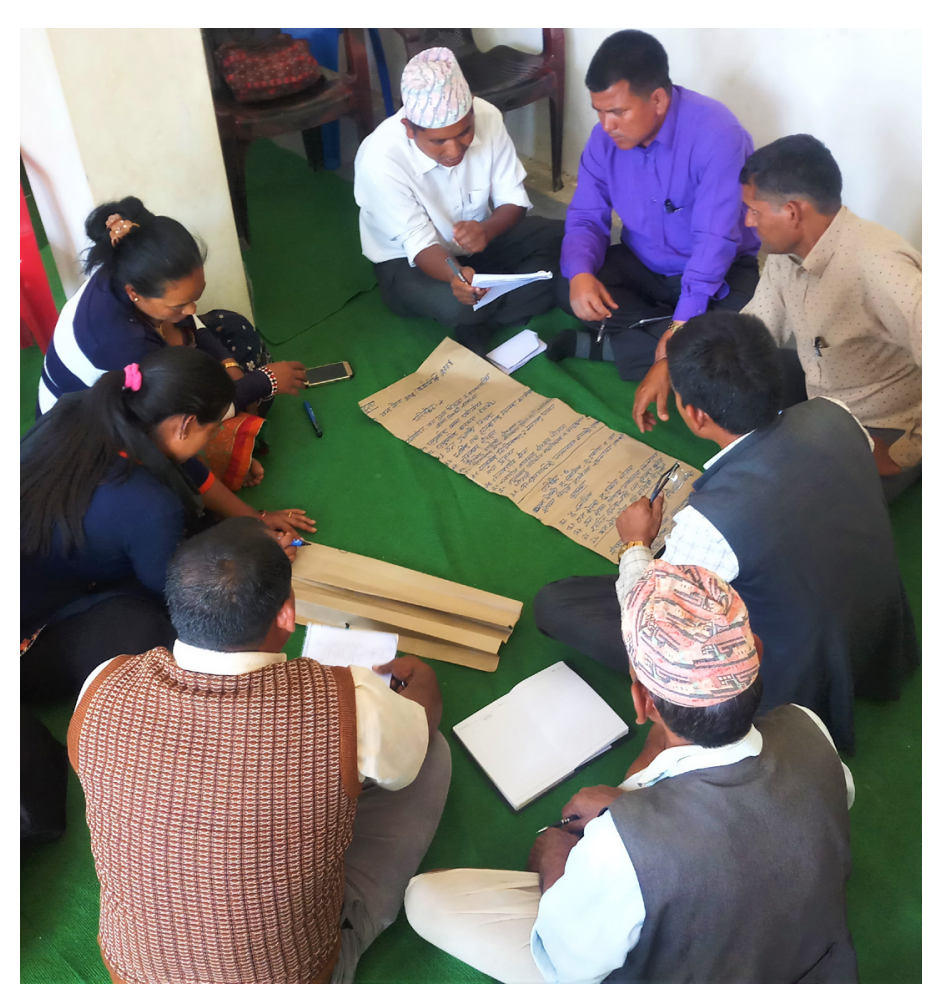




\section{Guiding the EU towards a stronger EU Action Plan on Human Rights and Democracy}

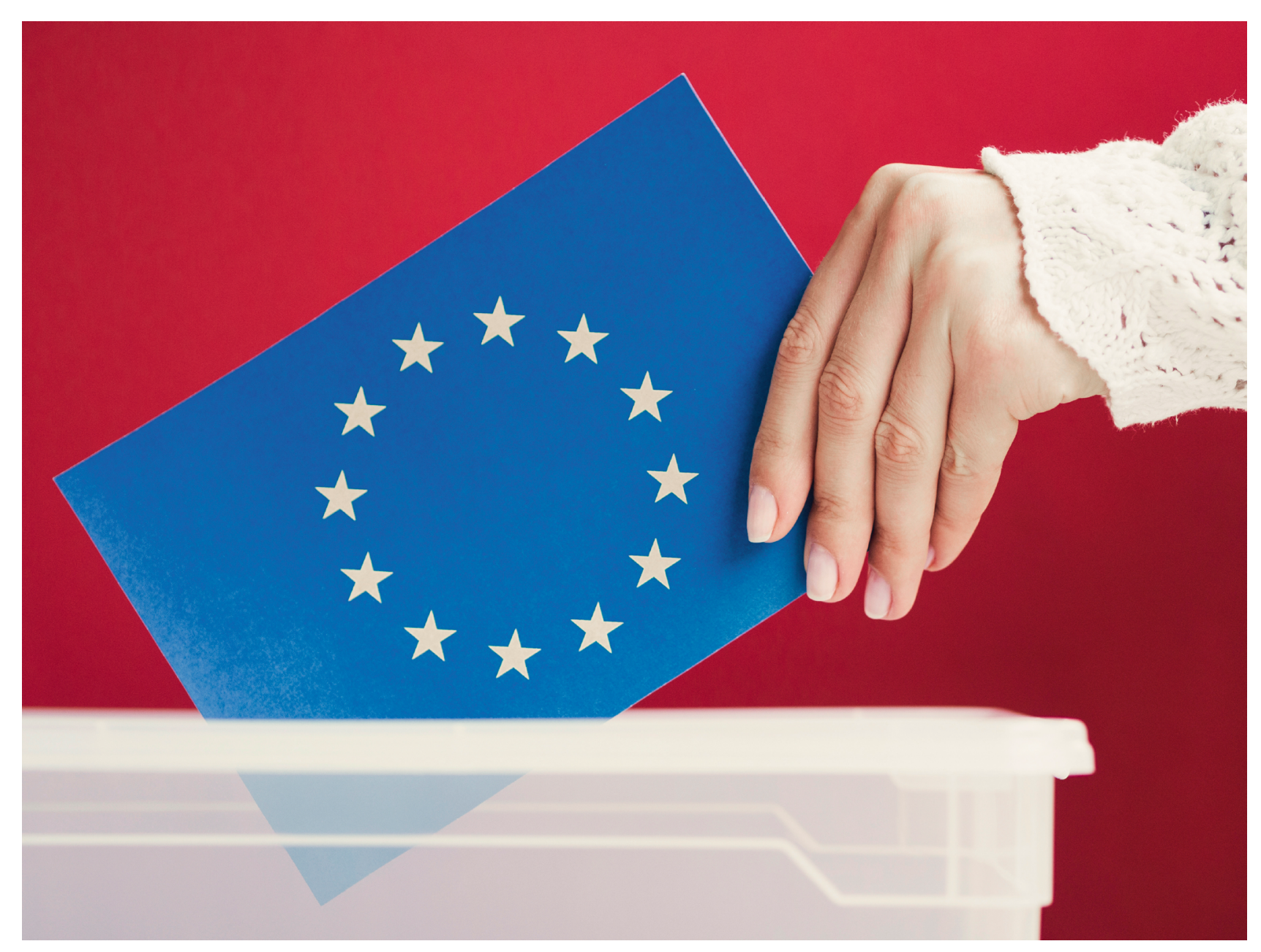

Photo credit: Freepik.com

In 2020, International IDEA Member States that are also European Union (EU) Member States jointly advocated for democracy within EU policies. This led to a major achievement on a key EU policy initiative, the EU Action Plan on Human Rights and Democracy 2020-2024.

International IDEA's Regional Europe Programme has contributed to the drafting process and decisionmaking of the EU Action Plan since 2019. It has done so through joint statements with democracy partners, a position paper to the online consultation, presentations to EU Member States, and inputs to International IDEA and EU Member States that negotiated on the text in the EU Council.

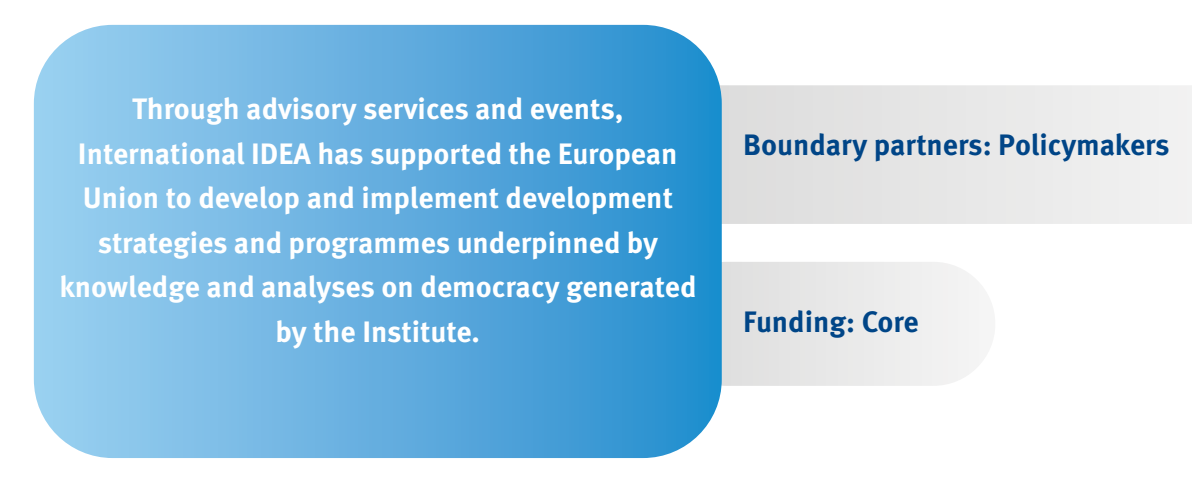

The Action Plan sets out ambitions and priorities for democracy in the EU's external relations over the next five years. It operationalizes the further strengthening of the EU's global leadership on democracy and provides guidance for EU delegations in their actions.

International IDEA contributions that made it into the Action Plan include:

- enhanced mainstreaming of democracy throughout the Action Plan, acknowledging that human rights and democracy are interdependent and mutually reinforcing;

- inclusion of the Action Plan to support the development of comparative knowledge on human rights and democracy for more evidence-based programming and action;

- enhanced progress monitoring of the Action Plan through the provision of a framework to track its implementation; and

- more attention to supporting political parties and parliaments, the role of digital technologies in democracy and the inclusion of artificial intelligence in democratic development actions, and the role of EU delegations in pursuing the Action Plan's objectives.

After the conclusion of negotiations in the EU Council Working Party on Human Rights, the Action Plan on Human Rights and Democracy 2020-2024 was adopted by ministers in the EU Foreign Affairs Council on 19 November 2020. The text includes stronger ambitions and actions on democracy than ever before, which reflects the true joint effort between EU institutions, democracy partners and Member States.

International IDEA's Secretary-General participated as a speaker in the online launch event of the European External Action Service to celebrate the adoption of the Action Plan, which was attended by nearly 1,000 participants around the world. The invitation illustrated the EU's appreciation of the partnership with International IDEA and our work in support of democracy. 


\section{International IDEA helps EU's pandemic response focus on democracy}

\section{COVID19: GLOBAL MONITOR}

Impact on human rights and democracy

\section{Live event}

\section{July, 10.00 CET}
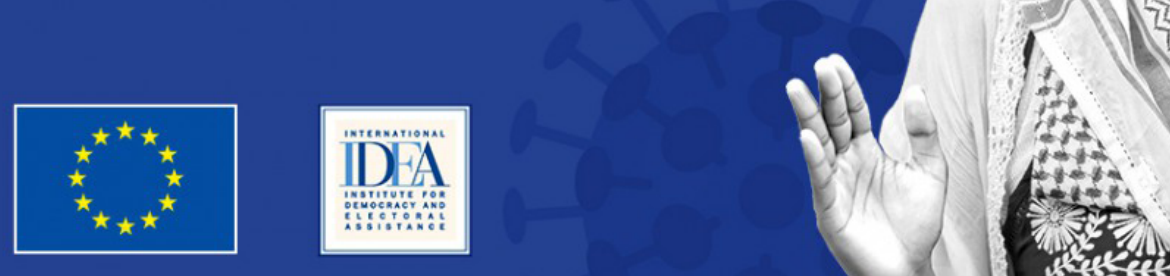

Photo credit: European Commission

Soon after the Covid-19 crisis broke out, International IDEA started to engage with the European Union (EU) to ensure it would include a democracy focus in its global pandemic response. Ultimately, this led to EU policies and EU representatives at the highest levels underlining the need to stand up for democracy during the pandemic. The effects of the crisis on the functioning of democracy have thus become a central tenet of EU action.

In November 2020, the EU adopted its new Human Rights and Democracy Action Plan, which details its plans to support democracy globally. Covid-19 is a recurring theme throughout the text. In December 2020, leading newspaper Politico highlighted the greatest achievement of European Commissioner for International Partnerships Jutta Urpilainen as her support to International IDEA's 'Global Monitor of Covid-19's impact on Democracy and Human Rights'. Within a short period of time, the relationship between democracy and Covid-19 became a crucial topic for the EU.

This change in practice can be attributed to the efforts of many democracy actors that engage with the

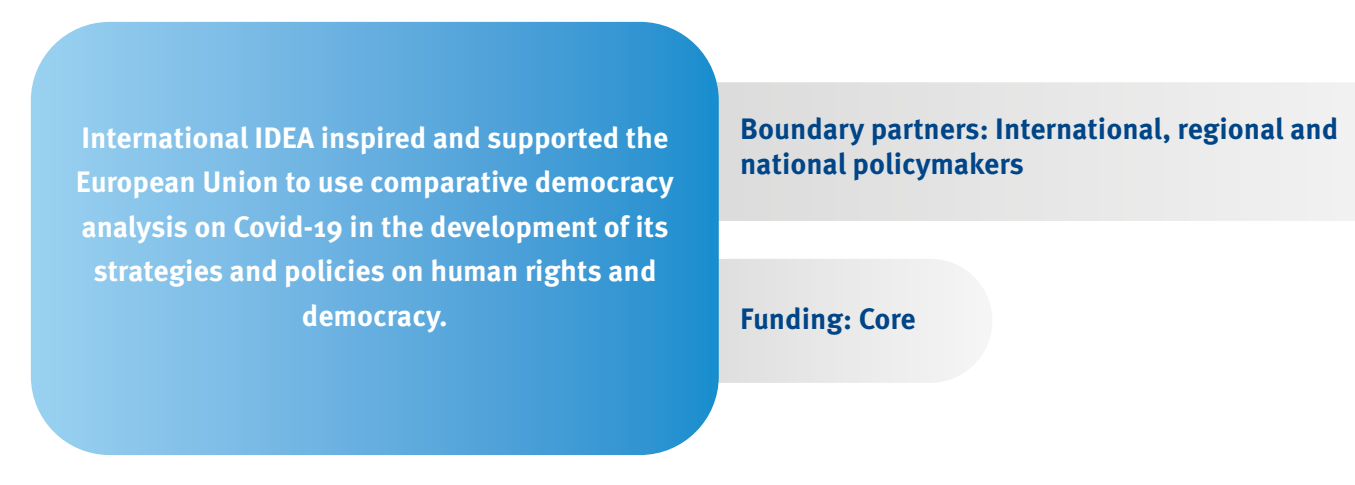

EU, but several International IDEA initiatives importantly contributed to this shift. In April, Sweden hosted its first International IDEA presentation on the pandemic's impact on democracy for a group of 15 EU Member States. This helped put the topic on the agenda of those negotiating the EU's Human Rights and Democracy Action Plan. In June, International IDEA launched its Call to Defend Democracy campaign, which received extensive coverage in EU-focused media.

Co-signatories of the campaign included all major European democracy support organizations, as well as many former European heads of state. This subsequently paved the way for the EU to fund Internationa IDEA's Global Monitor of Covid-19's impact on democracy and human rights. In July, European Commissioner for International Partnerships Jutta Urpilainen launched the Monitor. In October members of the European Parliament praised the tool during its presentation to the Subcommittee on Human Rights.

In September, International IDEA, the European Parliament and other partners co-organized a series of seven pandemic-focused high-level events to mark International Democracy Week at the EU. There, President of the European Parliament David Sassoli highlighted the importance of democratic systems in overcoming pandemic-related challenges, as did European Commissioner for Justice Vera Jourova. The events attracted a total of nearly 2,000 viewers.

In autumn, the European Parliament referred to International IDEA research in its Covid-19 debates, and representatives of the Directorate-General for Justice and Consumers of the European Commission participated in expert roundtables on Special Voting Arrangements during the pandemic.

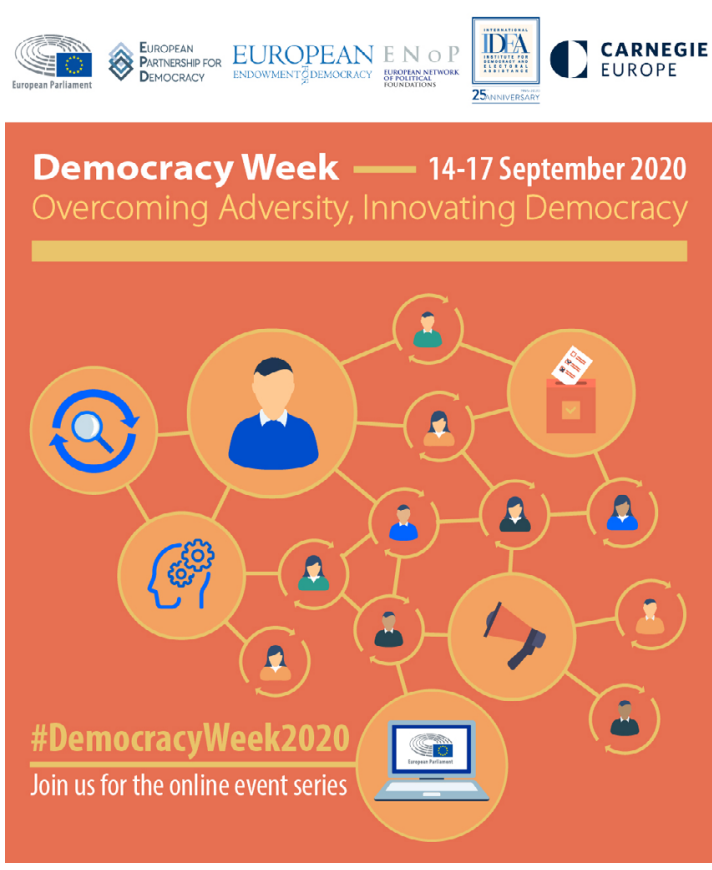




\section{Advancing SDG 16}

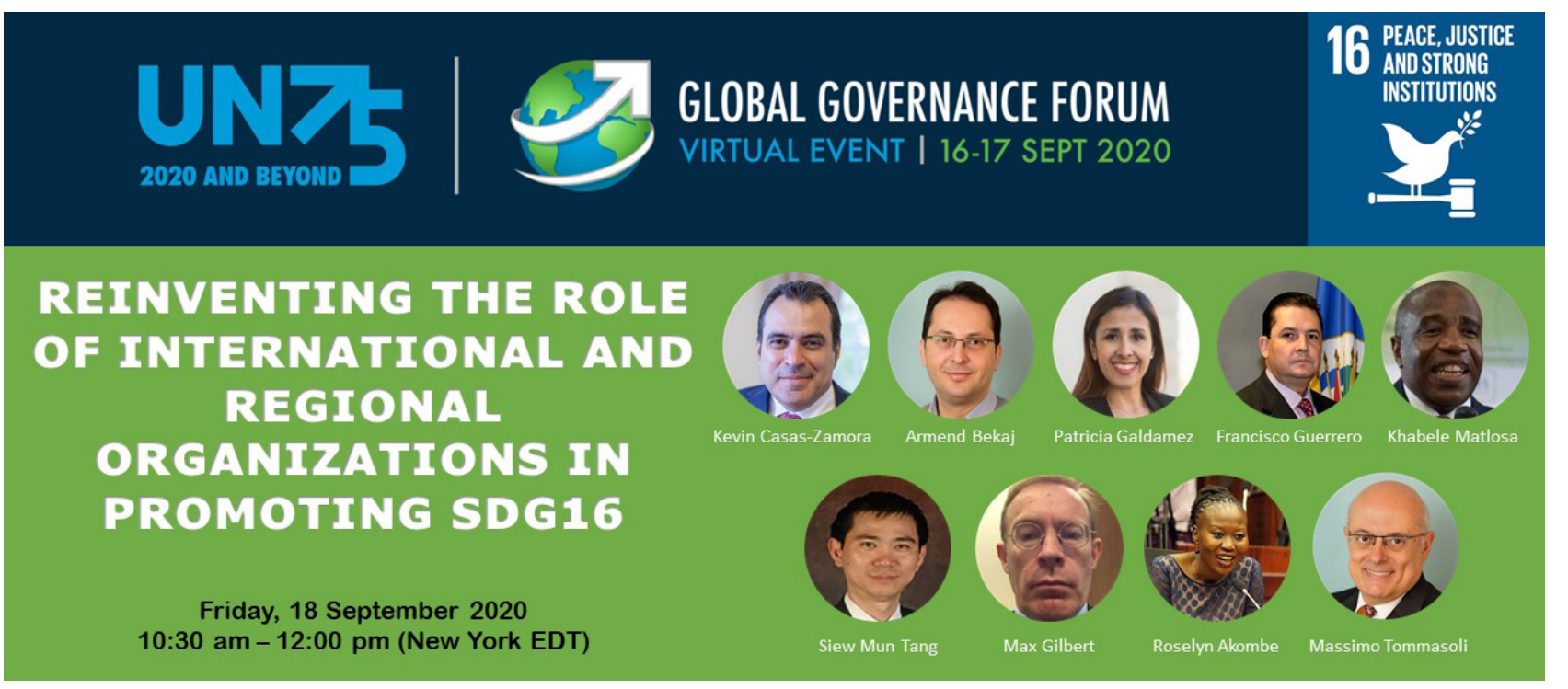

The SDG16 Data Initiative (DI) was launched in July 2016 by partner organizations seeking to support the open and holistic tracking of commitments made by 193 UN Member States captured on SDG16+ and the 2030 Agenda for Sustainable Development. International IDEA leads the Secretariat of the SDG16DI in 2020 and 2021. International IDEA produced a series of publications and events designed to evaluate global progress on Sustainable Development Goal 16 (SDG16).

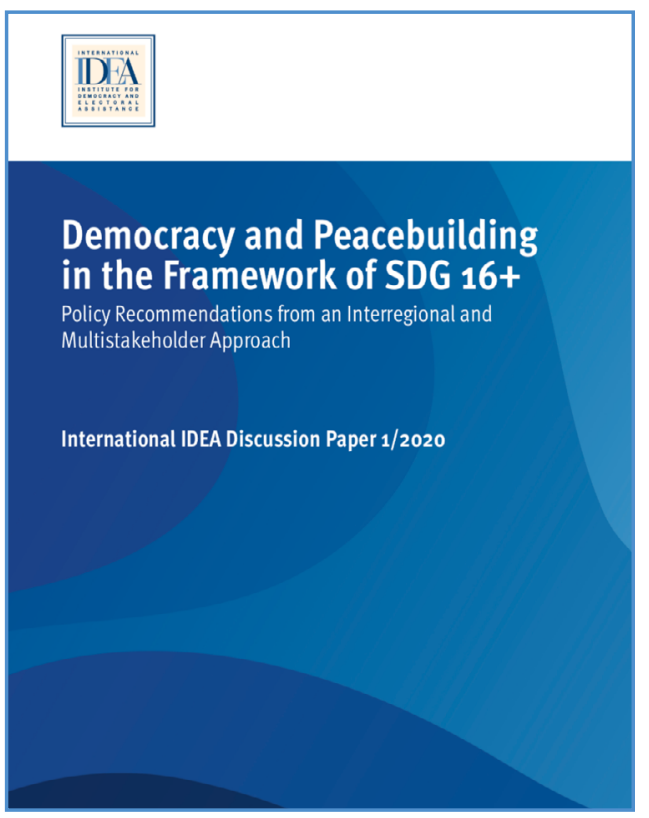

\begin{abstract}
The discussion paper on 'Democracy and Peacebuilding in the Framework of SDG 16+ Policy Recommendations from an Interregional and Multistakeholder Approach' was published at the beginning of the year.

As part of its policy advocacy work on the importance of non-official data within the 2030 Agenda, the Office of the Permanent Observer for International IDEA to the UN organized with the SDG16 Data Initiative partners two events on the margins of the UN Statistical Commission (March) and the High-Level Political Forum (July). These events underscored the importance of coordination among different partners, including the Praia City Group on Governance Statistics, the Global Alliance for Reporting Progress on Peaceful, Just and Inclusive Societies, and other stakeholders and partners in the SDG16DI.
\end{abstract}

The July event highlighted the special challenges associated with measuring trends related to achieving SDG16 in the context of the exceptional circumstances brought about by Covid-19 and its impact on democracy and human rights. It also discussed a possible way forward explored by both nationa statistical offices and non-official data providers to fill the gaps in data gathering and analysis created by the pandemic crisis.

Furthermore, International IDEA published GSoD In Focus No. 11, 'Monitoring Achievements on Sustainable Development Goal 16 2015-2019: A Global State of Democracy Indices Perspective'. This publication presents key findings on tracking progress on SDG16 using Global State of Democracy (GSoD) Indices data and showcases progress on SDG16 derived from the GSoD Indices covering 158 countries for the period 1975-2019.

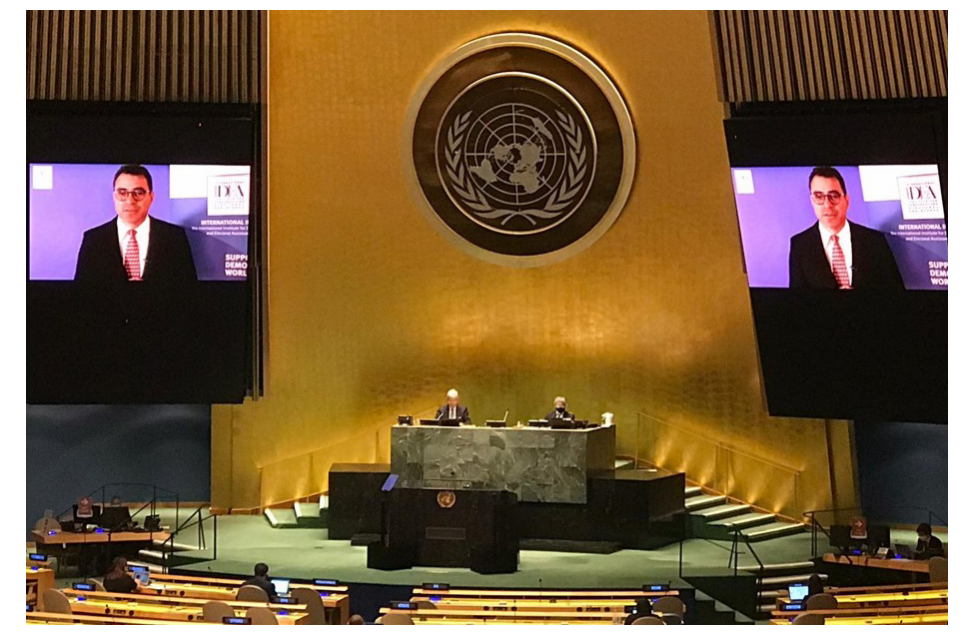

The GSoD In Focus was presented by the Democracy Assessment team at a virtual event entitled 'Reinventing the role of international and regional organizations in promoting peaceful, just and inclusive institutions in times of crisis: What was done and what is next?'organized by International IDEA's InterRegional Dialogue on Democracy, led by our New York Office, with high-level participation from the Stimson Center, Community of Democracies, Organization of American States, African Union Commission, Association of South East Asian Nations and the Council of Europe. The discussion explored the results and challenges faced in the implementation of SDG16+, and how global and multistakeholder initiatives could further collaborate and partner with the United Nations and civil society to ensure implementation of SDG16+ in the coming years.

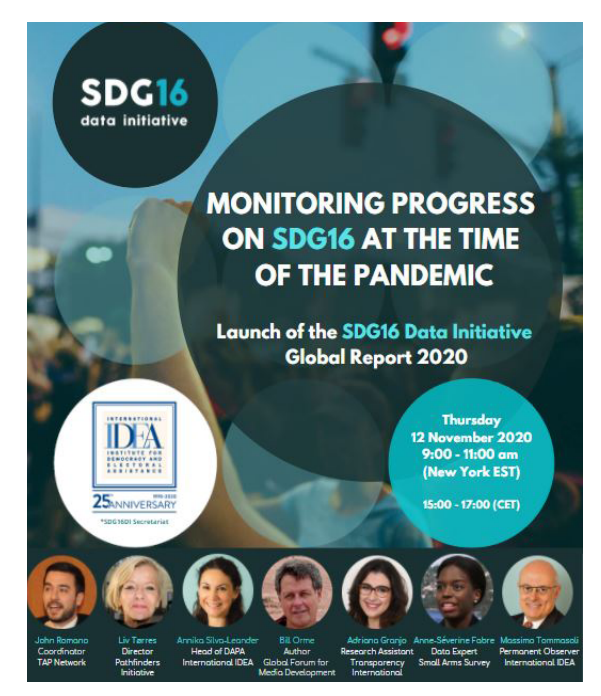

In November, the SDG16 DI launched its fourth annual Global Report, a consolidation of quality data generated by the collaborative efforts of 17 organizations working on related issues. The report gives governments, UN officials, civil society actors, academia and other stakeholders a resource to help understand progress on the SDG16 targets. It also provides an evidence base for identifying gaps in the implementation and monitoring of SDG16, and for altering the course to accelerate implementation where needed. In addition, the report offers a holistic view of progress under each of the SDG16 targets within the SDG16+ conceptual framework. The report was launched via a virtual event organized by the Permanent Observer of International IDEA to the UN, which included the participation of the Democracy Assessment team in the discussion panel. 


\section{0 Review In Numbers}


International IDEA in the news and knowledge resources

\section{Geographic spread of media mentions}

Top 10 countries for media mentions

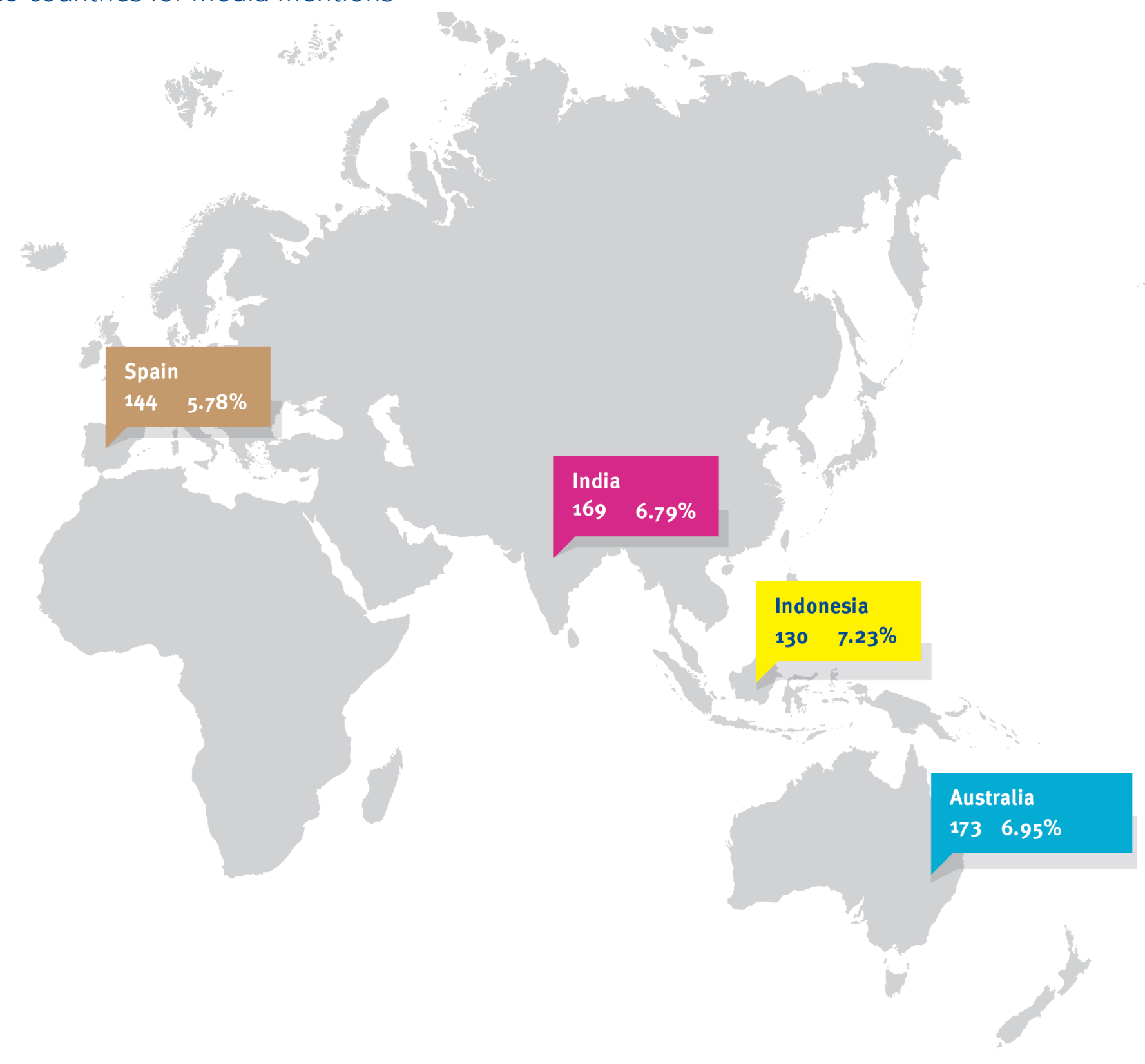

Disclaimer: Maps presented in this report do not imply on the part of the Institute any judgement on the legal status of any territory or the endorsement of such boundaries, nor does the placement or size of any country or territory reflect the political view of International IDEA. Maps are used in order to add visual clarity to data.

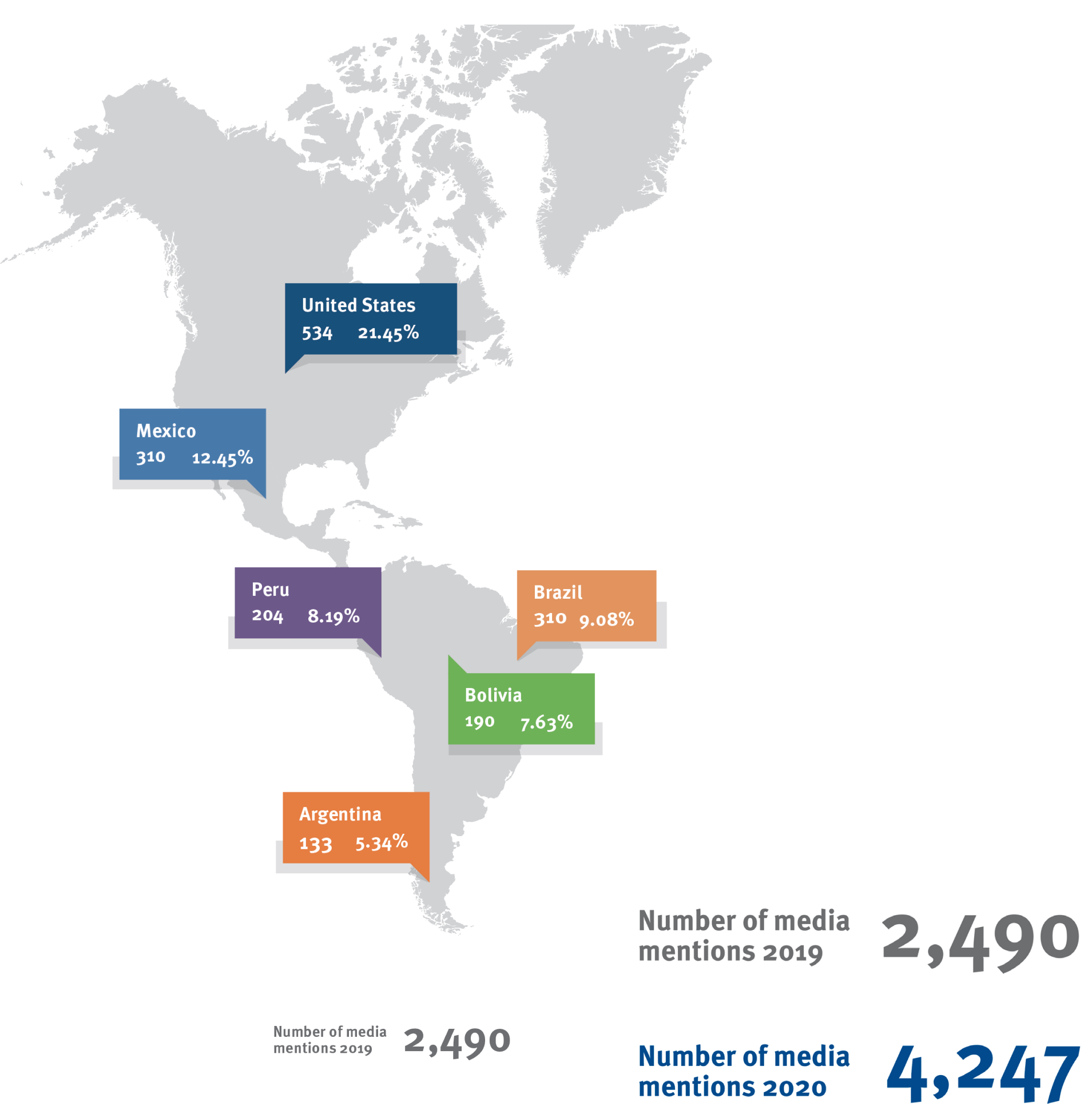


Top 10 International IDEA publications

By number of citations from products published since 1995

\section{4,600}

El impacto de las cuotas

Women in Parliament:

Beyond Numbers

Democratic Transitions:

Conversations with World Leaders

Electoral System Design:

The New International

IDEA Handbook

Direct Democracy: The

International IDEA Handbook

Voting from Abroad:

The International IDEA Handbook

The Global State of Democracy

2019: Addressing the Ills,

Reviving the Promise

Funding of Political Parties and

Election Campaigns: A Handbook

on Political Finance

Deepening Democracy: A

Strategy for Improving the

Integrity of Elections Worldwide

Voting from Abroad

The International IDEA Handbook

International IDEA 2020 publications produced

By type

国 Total 92

7,150

6,080

4,940

4,600

4,210

3,840

2,910

2,470

2,370
Event report

Primer

Technical paper

Guide

GSoD In Focus

Constitution Brief

Internal document

Case study

Report

Policy paper

Discussion paper

Policy brief

Overview

Fact sheet

Institutional

Handbook (chapter)

92 
International IDEA 2020 publications produced By language
圆 ${ }_{\text {number }}^{\text {Total }} \mathbf{9 3}$

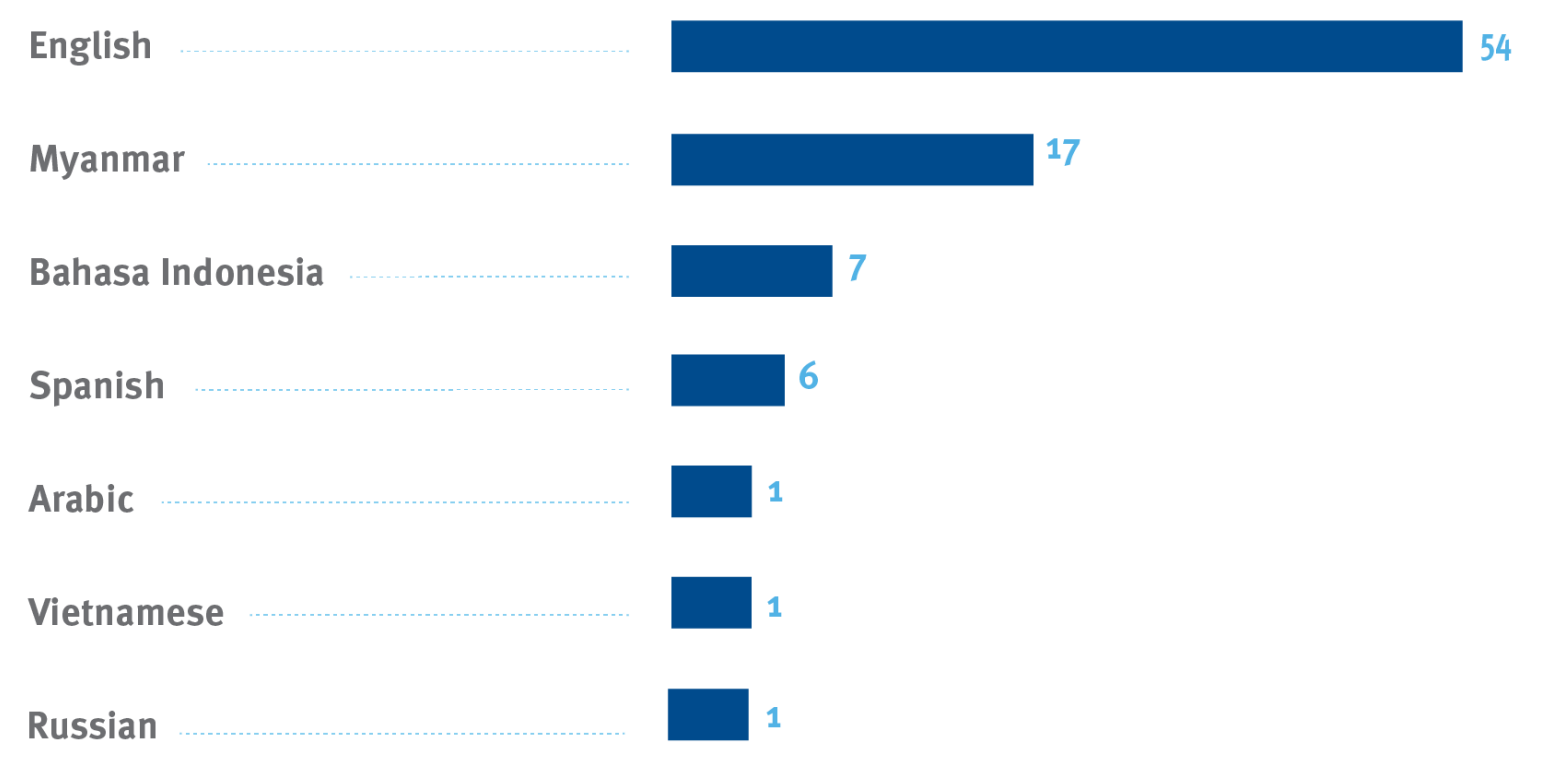

\section{Number of publication downloads} Top 10 countries

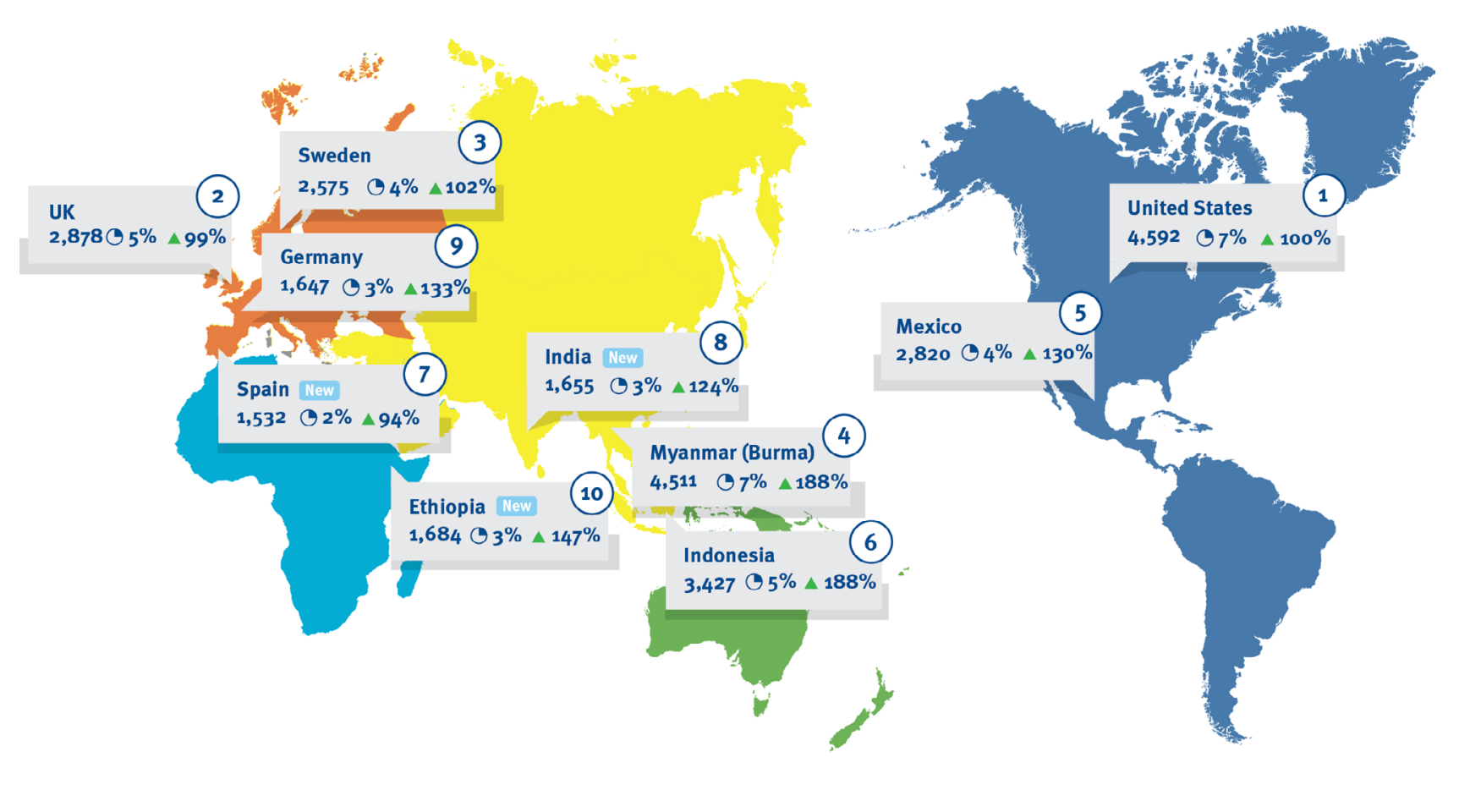

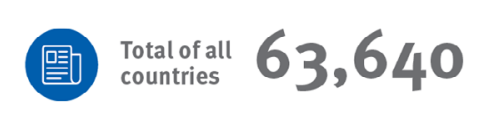

Europe
Africa
Asia
Increases from the 2019 to 2020 calendar year.




\section{Top 10 publications downloads}

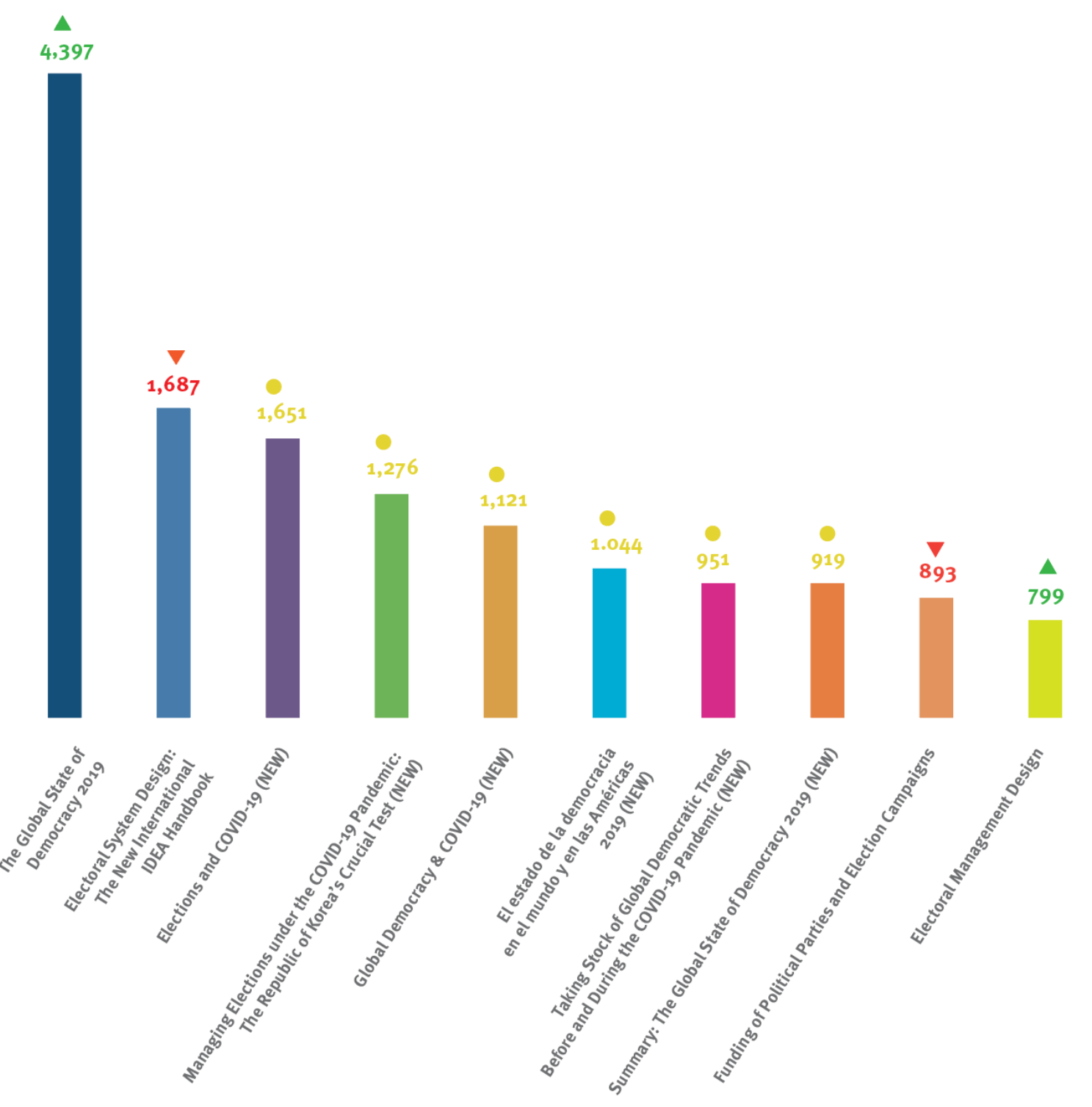

\section{Top News}

1. El impacto del coronavirus en el futuro de América Latina

2. Los desafíos a la democracia en América Latina

3. Los grandes desafíos del COVID-19 y su impacto en la democracia

4. Elections during COVID-19: Considerations on how to proceed with caution

5. The impact of the coronavirus in Latin America's future

6. Civil society in times of the coronavirus: reinventing its role

7. "Artivismo" Arte +Activismo: una propuesta para la construcción de ciudadanía

8. Elecciones durante el COVID-19: Consideraciones sobre cómo proceder con precaución

9. COVID-19 crisis threatens democracy, leading world figures warn

10. The instruments of direct democracy

\section{Top Events}

1. Democracy Day in the Time of the Pandemic: A Sustainable Response to the Global Crisis based on Multilateralism and the Rule of Law

2. The impact of COVID-19 on democracy

3. The Global Monitor of COVID-19's Impact on Democracy and Human Rights -- A one-stop tool to hold governments to account

4. Call for Papers: Women in Politics

5. Democracy, human rights and the pandemic: impact and opportunities

6. The Future of Representation and Political Parties: Opportunities and Challenges

7. WEBINAR: COVID-19 and Special Voting Arrangements: What can EMBs do to prepare for elections?

8. Democracy Talks in Manila - The Role of Youth Voices in Philippine Democracy

9. The Impact of the COVID-19 Crisis on Constitutionalism and the Rule of Law in Southern Africa

10. Webinar: Democracy in the times of Corona 


\section{New Followers, Impressions and Mentions during 2020}

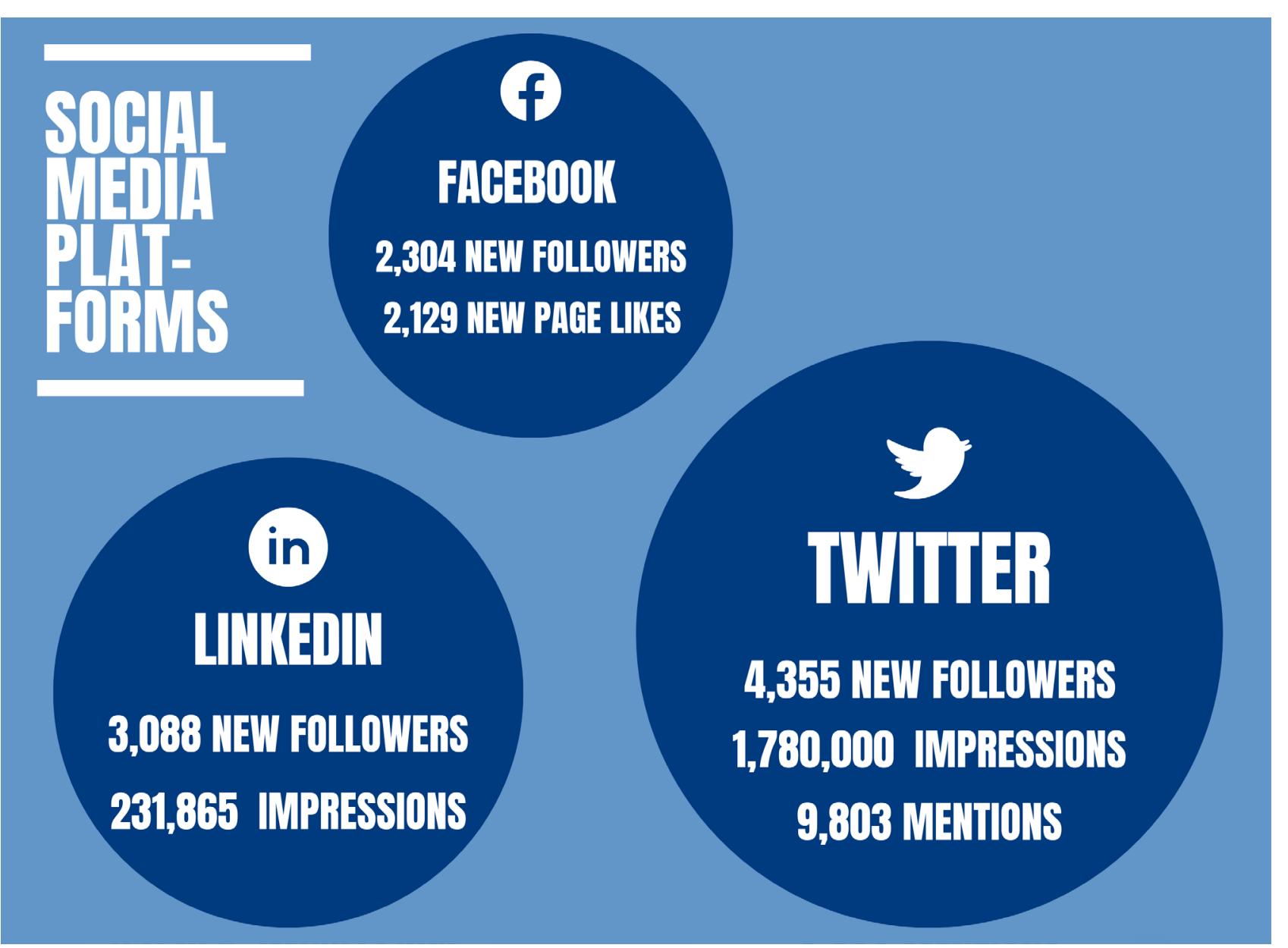

\section{Events and Trainings 2020 - Core funded}

\begin{tabular}{|l|l|}
\hline Number of Events & 160 \\
\hline $\begin{array}{l}\text { Number of } \\
\text { Participants }\end{array}$ & 8807 \\
\hline Number of Trainings & 17 \\
\hline $\begin{array}{l}\text { Number of } \\
\text { Participants }\end{array}$ & 235 \\
\hline
\end{tabular}

\section{Events}

Events are an essential part of International IDEA's public outreach and visibility. In addition to enabling the exchange of knowledge and ideas, they allow the Institute to build and strengthen vital global partnerships.

The shift to virtual meetings prompted by the Covid-19 pandemic allowed the Secretary-General to take part in 86 webinars, panel discussions and conferences, reaching thousands of participants around the world. He was invited to speak at the High-level Meeting to Commemorate the Seventy-fifth Anniversary of the United Nations, as well as the Swedish Parliament celebration of the 75th Anniversary of the United Nations, and our experts have given testimony before the US House of Representatives, the Australian Senate and the Parliament of the Australian state of Victoria.

In the weeks surrounding the International Day of Democracy, the Secretary-General participated in a wide array of events, many of which were organized in partnership with peer organizations and donor such as the European Endowment for Democracy, the European Network of Political Foundations, the International Law Development Organization, the Parliamentary Center in Canada, World Movement for Democracy and the Stimson Center.

Later in September, Dr Casas-Zamora took part in an international online seminar organized by the Election Commission of India and A-WEB on 'Issues, Challenges and Protocols for Conducting Elections during Covid-19: Sharing Country Experiences'. In the seminar's closing session, he distilled five key lessons on holding elections during the pandemic.

At the annual Melbourne Forum, co-organized by International IDEA and the Constitution Transformation Network at Melbourne Law School, the Secretary-General summarized the forum's discussions and highlighted an important lesson-that the pandemic has exposed and enhances pre-existing ills in democracies all over the world such as leadership deficits, social inequalities, polarization, weak governance structures, underinvestment in public goods and the erosion of trust in political institutions.

Throughout the year the Secretary-General also represented International IDEA in several high-level events hosted by the European Union such as the launch of the Global Monitor of Covid-19's Impact on Democracy and Human Rights together with Jutta Urpilainen, the EU Commissioner for International Partnerships. The Secretary-General was also one of the main speakers at the launch of the new EU Action Plan on Human Rights and Democracy 2020-2024. In his remarks at this launch, he emphasized the need for the EU to not only prioritize the defence of democracy but to reinvent it through mutual learning. He also took part in several events co-organized with the EU Commission and the EU Parliament during the year. 


\section{Partnerships in 2020}

Facilitating partnerships for multilateral action for democracy assistance

\section{WEBINAR}

Democratic Resiliency

in times of World Crisis:

Challenges and Opportunities

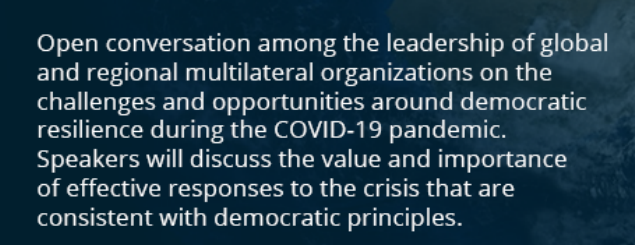

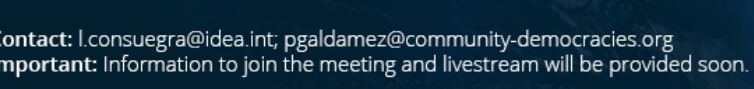

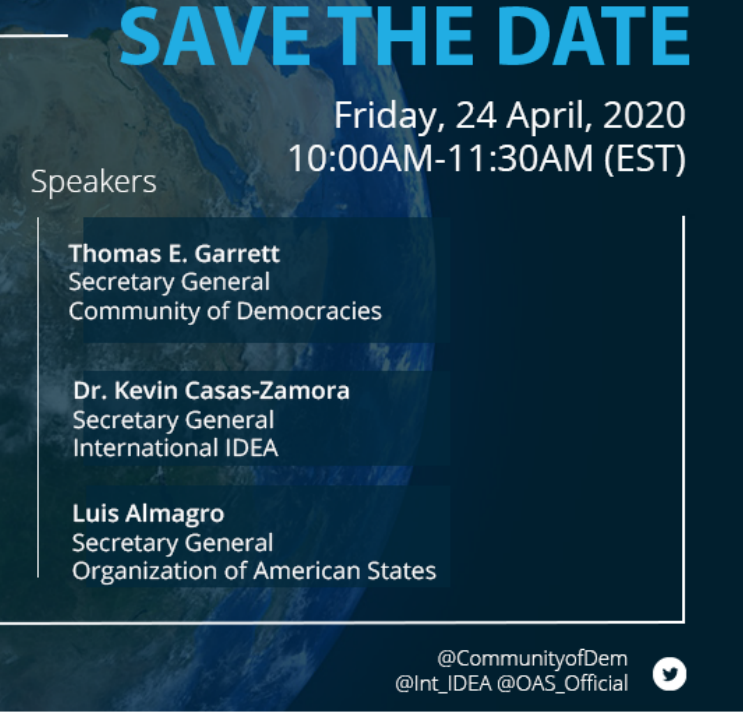

\begin{tabular}{l|l|} 
Community \\
of Democracies
\end{tabular}

The Office of the Permanent Observer for International IDEA to the United Nations (UN) has established itself as an institutional hub to enhance collaboration with the UN Secretariat and UN agencies, and with key partners including Member States, governments, global and regional organizations, civil society organizations, think tanks and universities, and other associations and initiatives that work on issues related to democracy building.

Throughout 2020, the following partnerships and collaborations were established or strengthened, and International IDEA, through its office in New York, played a leading role.

\section{Inter-Regional Dialogue on Democracy (IRDD)}

The IRDD is the only global platform that gathers international and regional organizations, together with civil society organizations and other key stakeholders, for discussions on issues related to democracy and good governance. In 2020, the IRDD led or engaged on:

- Publication of the discussion paper 'Democracy and Peacebuilding in the Framework of SDG16+ Policy Recommendations from an Interregional and Multistakeholder Approach?
- An online conversation between the secretaries-general of International IDEA, the Community of Democracies and the Organization of American States to discuss the impact of the Covid-19 pandemic on democratic resilience.

- Regional consultations organized by the Stimson Center in Washington, DC to gather input and formulate policy recommendations to mark the 75th anniversary of the UN and the restructuring of the UN system.

- The Regional and International Organizations Working Group is an initiative of the Global Partnership for the Prevention of Armed Conflict (GPPAC), which seeks to create an operational addition to the IRDD platform to support its efforts and expand the pool of organizations that contribute to it. International IDEA, GPPAC, the UN Development Programme and the Community of Democracies will lead this initiative in 2021.

\section{SDG16 Data Initiative}

As in previous years, International IDEA led the launch of the 2020 Global Report of the SDG16 Data Initiative to support the open and holistic tracking of the commitments made by all 193 UN Member States captured in SDG16+.

Other partnerships and initiatives

- The New York Office has a close relationship with Pathfinders for Peaceful, Just and Inclusive Societies initiative, which is a group of 38 UN Member States, international organizations, globa partnerships, civil society and the private sector that seeks to accelerate action on the Sustainable Development Goal (SDG) targets for peace, justice and inclusion (SDG16+).

- The Permanent Observer for International IDEA to the UN has recently joined as a Thought Partner of the Workstream 1 - Constitutional \& Legal Tools of the Prevention Project hosted by the Center for Human Rights and Global Justice, NYU School of Law.

- The New York Office has also engaged with other universities and youth organizations interested in actively discussing matters related to democracy. International IDEA staff have engaged with Universidad del Norte (Colombia), Universidad del Atlántico (Colombia), Corporación IPSA (Colombia), Instituto Tecnológico de Monterrey (Mexico) and Friendship Ambassadors Foundation (USA). The Office of the Permanent Observer for International IDEA to the United Nations has also actively engaged with private foundations and think tanks based in New York and Washington, such as the Ford Foundation, the Open Society Foundations, National Endowment for Democracy, International Foundation for Electoral Systems, Sustainable Development Solutions Network and the Rockefeller Brothers Fund. It also engaged with organizations such as the World Bank, the InterAmerican Development Bank and CAF - Banco de Desarrollo para America Latina. 
Memoranda of understanding, grant agreements and strategic partnership agreements

\begin{tabular}{|c|c|c|}
\hline \multicolumn{3}{|c|}{ Signed projects, 2020} \\
\hline Name of project & Donor & Country/Team \\
\hline $\begin{array}{l}\text { Incremento de la transparencia y la } \\
\text { confianza pública sobre la gestión de } \\
\text { las elecciones generales del } 2020\end{array}$ & EU & $\begin{array}{l}\text { Bolivia/Latin America and the } \\
\text { Caribbean }\end{array}$ \\
\hline $\begin{array}{l}\text { Support to emerging democratic } \\
\text { governance and PLGSP effectiveness }\end{array}$ & DFID & Nepal/Asia and the Pacific \\
\hline $\begin{array}{l}\text { CANDI dat@s - Promotion of informed } \\
\text { vote }\end{array}$ & FFO & $\begin{array}{l}\text { Bolivia/Latin America and the } \\
\text { Caribbean }\end{array}$ \\
\hline $\begin{array}{l}\text { Supporting the AGORA Portal for } \\
\text { Parliamentary Development }\end{array}$ & $\begin{array}{l}\text { Westminster Foundation for } \\
\text { Development }\end{array}$ & PPR/Global Programmes \\
\hline $\begin{array}{l}\text { Global Monitor of Covid-19's Impact on } \\
\text { Democracy and Human Rights }\end{array}$ & EU & DA/Global Programmes \\
\hline $\begin{array}{l}\text { Incremento de la transparencia y la } \\
\text { confianza pública sobre la gestión } \\
\text { del ciclo electoral correspondiente a } \\
\text { las elecciones generales de } 2020 \text { y } \\
\text { subnacionales de } 2021\end{array}$ & $\begin{array}{l}\text { Spanish Agency for International } \\
\text { Development Cooperation }\end{array}$ & $\begin{array}{l}\text { Bolivia/Latin America and the } \\
\text { Caribbean }\end{array}$ \\
\hline $\begin{array}{l}\text { Study on the Long-Term Effectiveness of } \\
\text { Electoral Assistance Approaches }\end{array}$ & EBA & EP/Global Programmes \\
\hline $\begin{array}{l}\text { Supporting Sudan's Democratic } \\
\text { Transition }\end{array}$ & Sida & Sudan/Africa and West Asia \\
\hline $\begin{array}{l}\text { Fortalecimiento de la capacidad de } \\
\text { gestión de los procesos electorales el } \\
\text { OEP }\end{array}$ & $\begin{array}{l}\text { Swiss Agency for Development and } \\
\text { Cooperation }\end{array}$ & $\begin{array}{l}\text { Bolivia/Latin America and the } \\
\text { Caribbean }\end{array}$ \\
\hline $\begin{array}{l}\text { Supporting accountable democratic } \\
\text { governance and active citizenry in } \\
\text { Kenya }\end{array}$ & $\begin{array}{l}\text { The Minister for Foreign Trade and } \\
\text { Development Cooperation of the } \\
\text { Netherlands }\end{array}$ & Kenya/Africa and West Asia \\
\hline $\begin{array}{l}\text { Asistencia Técnica para el } \\
\text { fortalecimiento del TE Panamá 2021- } \\
2022\end{array}$ & The Electoral Tribunal of Panama & $\begin{array}{l}\text { Panama/Latin America and the } \\
\text { Caribbean }\end{array}$ \\
\hline $\begin{array}{l}\text { Supporting Mali's Transition to Peace } \\
\text { and Democracy }\end{array}$ & Swedish Ministry for Foreign Affairs & Mali/Africa and West Asia \\
\hline $\begin{array}{l}\text { Informed Peruvian civil society } \\
\text { contributes to the implementation of } \\
\text { the recommendations of the EOM of the } \\
\text { EU } 2020\end{array}$ & EU & Peru/Latin America and the Caribbean \\
\hline $\begin{array}{l}\text { Support to Women Participation in } \\
\text { Constitution-making in South Sudan }\end{array}$ & DFID & South Sudan/ Africa and West Asia \\
\hline $\begin{array}{l}\text { Indigenous People's Champions for the } \\
\text { Philippines }\end{array}$ & EU & $\begin{array}{l}\text { Philippines/Asia and the Pacific } \\
\end{array}$ \\
\hline Promoting Good Governance in Bhutan & EU & Bhutan/Asia and the Pacific \\
\hline
\end{tabular}

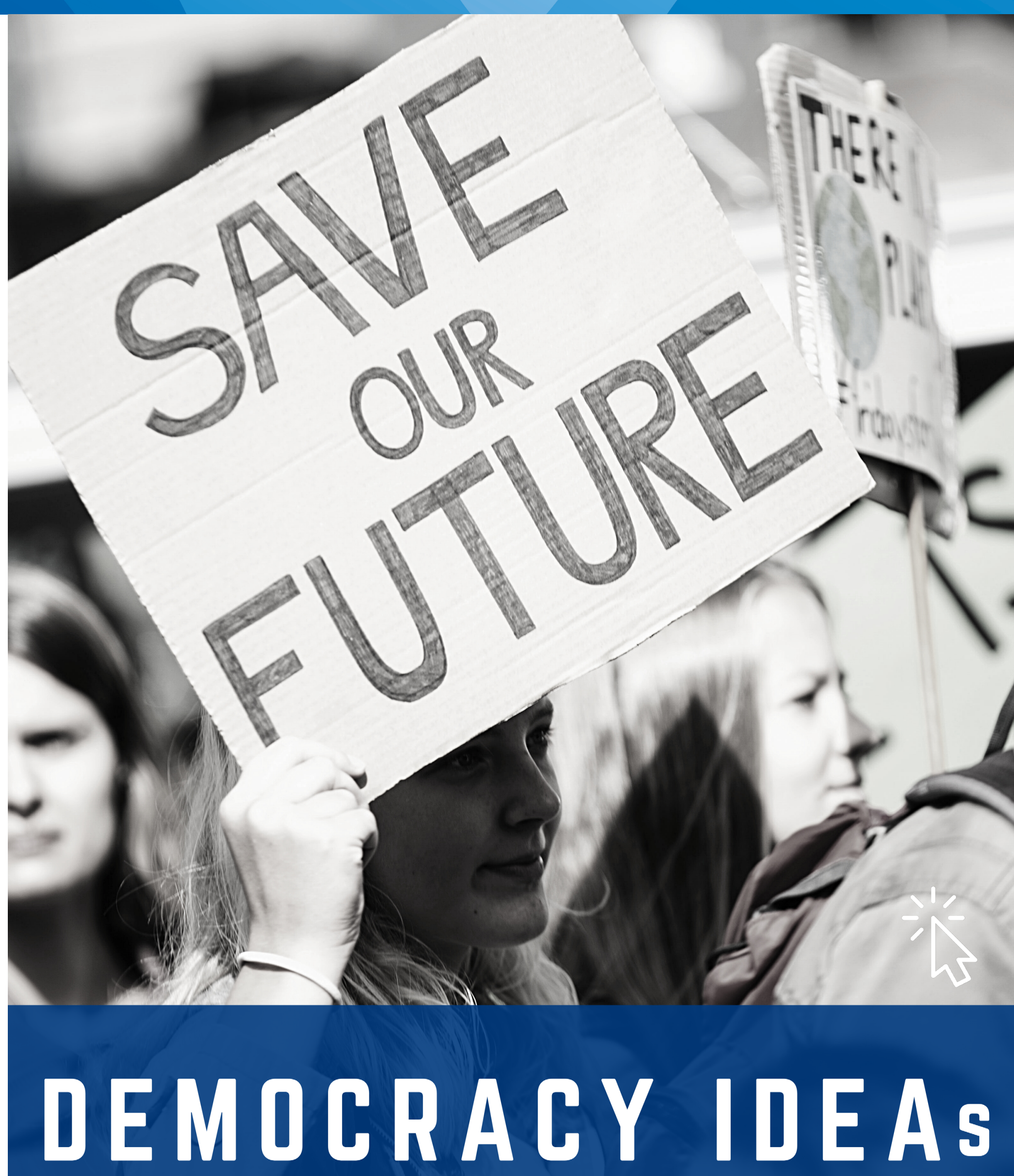

Click on the page to the right to access International IDEA's Podcast 'Democracy IDEAs'. 


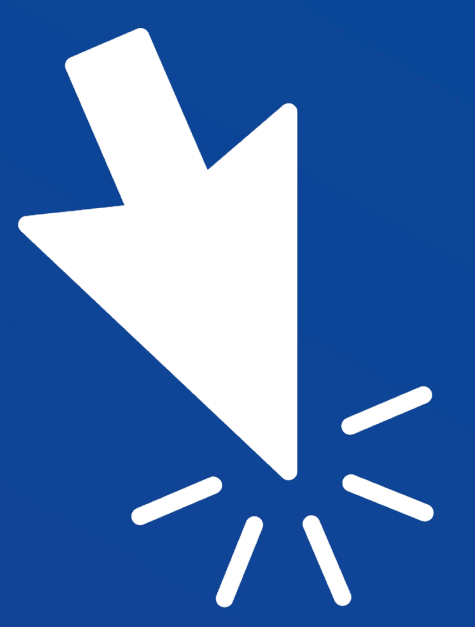

\section{Learning-based Management at International IDEA}

CLICK 


\title{
DEFENDING DEMOCRACY
}

\author{
Annual Outcome Report 2020
}

The International Institute for Democracy and Electoral Assistance (International IDEA) is an intergovernmental organization with the mandate to promote and advance democracy worldwide.

International IDEA contributes to the public debate on democracy and assists in strengthening processes, reforms, institutions and actors that build, advance and safeguard democracy, with a focus on electoral processes, constitution-building processes, and political participation and representation. Mainstreamed across all our work are gender and inclusion, conflict sensitivity and sustainable development.

International IDEA is governed by a council composed of its Member States and assisted by a Board of Advisers.

International IDEA's Member States are democracies and provide both political and financial support to the work of the organization. They are Australia, Barbados, Belgium, Benin, Botswana, Brazil, Cabo Verde, Canada, Chile, Costa Rica, Dominican Republic, Finland, Germany, Ghana, India, Indonesia, Luxembourg, Mauritius, Mexico, Mongolia, Namibia, the Netherlands, Norway, Panama, Peru, the Philippines, Portugal, South Africa, Spain, Sweden, Switzerland, Tunisia and Uruguay. Japan has observer status.

INTERNATIONAL INSTITUTER INSTITUTE FOR
DEMOCRACY AND DEMOCRACY AND $\begin{array}{llll}E & \\ A & \text { S S I S T A A N C E }\end{array}$
International IDEA

SE-103 34 Stockholm

SWEDEN

+4686983700

info@idea.int

www.idea.int 